\title{
EXTRAÇÃO DO FÓSFORO SOLÚVEL, ORGÂNICO E TOTAL EM SOLOS DO ESTADO DE SÃO PAULO POR DIVERSOS MÉTODOS QUÍMICOS, E DISPONIBILIDADE DESTE ELE- MENTO UTILIZANDO O FEIJOEIRO (Dhaseolus vulgaris, L.) E MILHO (Zea mays, L.)
}

\section{ALFREDO JOSÉ LOPÉZ PÉREZ}

Orientador: PROF. DR. ANDRE MARTIN LOUIS NEPTUNE

Dissertação apresentada à Escola Superior de Agricultusa "Luiz de Queiroz", da Universidade de São Paulo, para obtenção do titulo de Mestre em Solos e Nutrição de Plantas.

P I R A C I C A B A

Estado de São Paulo - Brasil

junho, 1982 
. ii.

A meus pais, Alfredo e Nena, e

a meus filhos Vivian, Lissette

e Alfredo, o bereso

A minha esposa creide Dedico 


\section{.iie.}

\section{AGRADECIMENTOS}

- Ao Prof. Dr. André Martin Louis Neptune, pelo estímulo durante os Cursos de Pós-Graduação, e sua orientação e amizade.

- Ao Prof. Dr. Toshiaki Kinjo e ao Prof. Dr. Eurípides Malavolta, por suas valiosas recomendações, amizade e apôio.

- Ao Dr. Takashi Muraoka, por todo o seu valio so aporte ao esclarecimento dos problemas apresentados no experimento, e sua desinteressada cooperação e amizade.

- Ao Prof. Antonio Assis Carvalho Filho, da UNESP, campus de Presidente Prudente, por sua valiosa e desin teressada colaboração na análise estatística do presente trabalho.

- Aos Srs. Marileuza Aparecida Bassi e João Odemir Salvador, da Seção de Fertilidade do Solo do CENA, Piracicaba, por seus valiosos auxílios na parte técnica.

- Ao Centro de Energia Nuclear na Agricultura (CENA), pela valiosa colaboração para a montagem do experimen to em casa-de-vegetação, e o fornecimento de equipamentos, la boratórios e reativos para as análises.

- A Universidad Nacional Experimental del Táchira (UNET), San Cristóbal, Venezuela, em especial nas pessoas do Dr. Rafael Pérez Levy e Dr. Marcial Alí Huggins, por ter me dado a oportunidade de efetuar o curso de Pós-Gradua- 
iv.

çao.

- A Escola Superior de Agricultura "Luiz de Queiroz" (ESALQ), a seus Professores e Funcionários, pela amí zade e apoio brindado.

- A minha querida esposa Cleide Cavichiolli de López, pela sua grande colaboração, estímulo e apōio em todo momento, assim como na correção idiomática do presente traba1ho. 
INDICE

pägina

1. INTRODUÇAO $\ldots \ldots \ldots \ldots \ldots \ldots \ldots \ldots \ldots \ldots \ldots \ldots \ldots \ldots \ldots \ldots \ldots$

2. REVISÃO DE LITERATURA $\ldots \ldots \ldots \ldots \ldots \ldots \ldots \ldots \ldots \ldots \ldots$

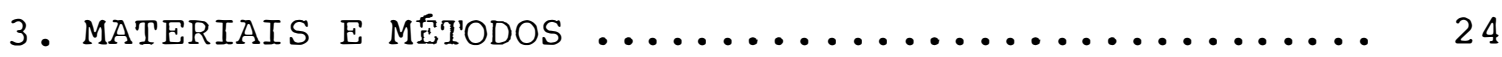

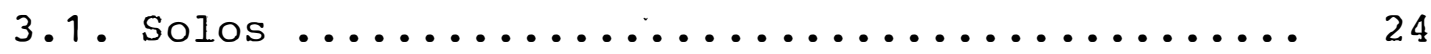

3.2. Métodos de análise química para fósforo ...... 25

3.2.1. Fósforo total $\ldots \ldots \ldots \ldots \ldots \ldots \ldots \ldots 26$

3.2.2. Fósforo solúvel .............. 26

3.2.3. Fósforo orgâni.co $\ldots \ldots \ldots \ldots \ldots \ldots \ldots .28$

3.3. Experiências em casa de vegetação .......... 28

3.4. Fós foro total na matéria vegetal seca ....... 30

3.5. Análise estatj̃stica $\ldots \ldots \ldots \ldots \ldots \ldots \ldots \ldots \ldots$

4. RESUlTADOS E DISCUSSÃO .................... 32

4.1. Análise química e mecânica de solos ........ 32

4.2. Análise química para fósforo em solo ........ 36

4.2.1. Fósforo solúvel .............. 36

4.2.2. Fós foro orgânico .............. 42

4.2.3. Fósforo total ................ 44

4.3. Ensaios em casa de vegetação ............ 50

4.3.1. Feijoeiro .................. 50

4.3.2. Milho ....................... 65

4.4. Correlações ...................... 78

4.4.1. Matéria vegetal seca e fósforo total na MVS, com fósforo solúvel no solo ..... 78 
4.4 .1 .1$. Feijoeiro ............... 78

4.4 .1 .2 . Milho ................... 81

4.4.2. Matéria vegetal seca e fósforo total na MVS, com fósforo orgânico no solo ..... 84 4.4.2.1. Feijoeiro ................ 84 4.4 .2 .2$. Milho ................... 86

4.4.3. Matéria vegetal seca e fósforo total na MVS, com fósforo total no solo ....... 86 4.4 .3 .1$. Feijoeiro ................. 86 4.4 .3 .2 . Milho .................... 89

4.4.4. Matéria vegetal seca e fósforo totai na MVS, com nîveis de fósforo aplicado ... 4.4.4.1.Feijoeiro ................ 91

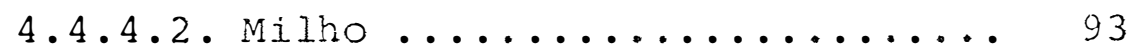

4.4.5. Matéria vegetal seca com fósforo total

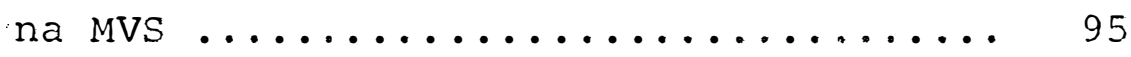

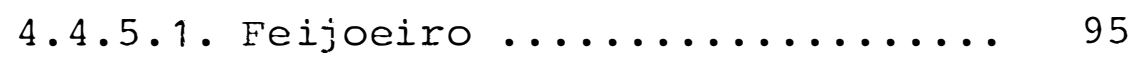

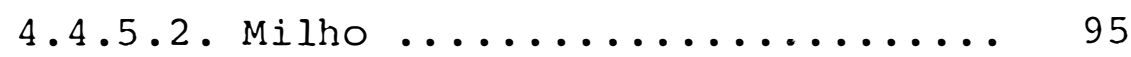

4.5. Sugestões para pesquisas posteriores ....... 97

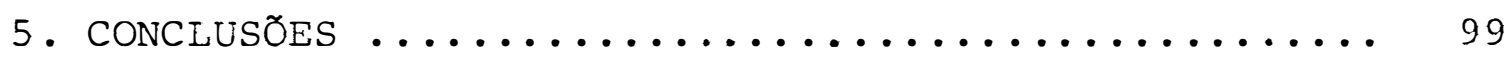

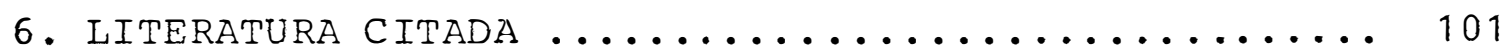


Tabela 1. Análise química dos solos ............. 34

Tabela 2. Análise granulométrica e umidade dos solos.

Tabela 3. Fósforo solúvel obtido por diferentes méto-

- dos de análise, para cinco solos do Estado de São Paulo ...................... 37

Tabela 4. Fósforo orgânico obtido por diferentes métodos de análise, para cinco solos do Estado

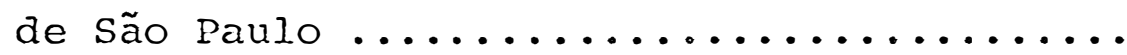

Tabela 5. Fósforo total obiido por diferentes métodos de análise, para cinco solos do Estado de

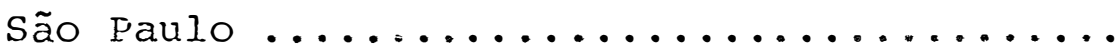

Tabela 6. Porcentagem de fósforo solúvel (Ps) segundo o método de análise empregado, e com referên cia ao método empregado para fósforo total (Pt) $\ldots \ldots \ldots \ldots \ldots \ldots \ldots \ldots \ldots \ldots \ldots \ldots \ldots \ldots \ldots \ldots \ldots$

Tabela 7. Porcentagem de fósforo orgânico (Po) segundo o método de análise empregado, e com referên cia ao método empregado para fósforo total.

Tabela 8. Matéria vegetal seca, e fósforo total na MVS, obtido em Feijoeiro cultivado em cinco solos 
do Estado de São Paulo, a diferentes níveis de fósforo adicionado (Pa) $\ldots \ldots \ldots \ldots \ldots \ldots$

Tabela 9. Produção relativa (PR日) de MVS no Feijoeiro, com referência a máxima produção obtida pa-

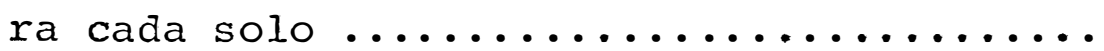

Tabela 10. Produção relativa (PRT) de MVS no Feijoeiro, com referência a máxima produção obtida em todos os solos $\ldots \ldots \ldots \ldots \ldots \ldots \ldots \ldots \ldots \ldots$

Tabela 11. Porcentagem de utilïzação eficiente (Us:) e incremento na produção $(\Delta \mathrm{Pr})$ no feijoeiro.

Tabela 12. Matéria vegetal seca e fósforo total na MVS, obtido em milho cultivado em cinco solos do Estado de São Paulo, a diferentes níveis de fósfóro adicionado (Pa) $\ldots \ldots \ldots \ldots \ldots \ldots \ldots$

Tabela 13. Produção relativa (PRS) de MVS no milho, com referência a máxima produção obtida para ca

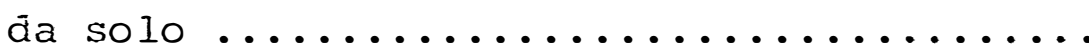

Tabela 14. Produção relativa (PRrin) de MVS no milho, com referência a máxima produção obtida em todos os solos $\ldots \ldots \ldots \ldots \ldots \ldots \ldots \ldots \ldots \ldots \ldots \ldots \ldots \ldots \ldots \ldots$

Tabela 15. Porcentagem de utilização eficiente (UE:) e incremento na produção $(\Delta \mathrm{Pr})$ no milho ..... 
Tabela 16. Coeficientes de correlação $(r)$, teste de $F$ (F) e significância estatỉstica (s), entre a matéria vegetal seca e/ou o fósforo total na MVS, no feijoeiro, e o fósforo solúvel do solo, obtido por diferentes métodos de

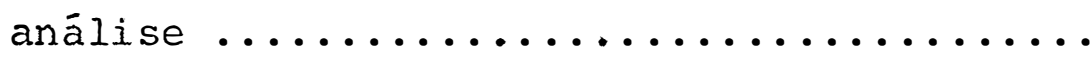

Tabela 17. Coeficientes de correlação (r), teste de F (F) e significância estatística (s), entre a matéria vegetal seca e/ou o fósforo total na MVS, no milho, com o: fósforo solüvel do solo, obtido por diferentes métodos de aná-

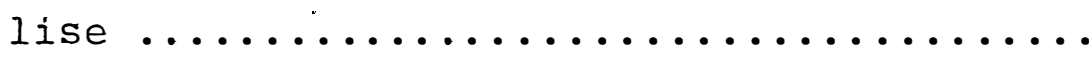

Tabela 18. Coeficientes de correlação $(r)$, teste de F (F) e significância estatística (s), entre a matéria vegetal seca e/ou o fósforo total na MVS de feijoeiro, com o fósforo orgânico do solo, obtido por diferentes métodos de

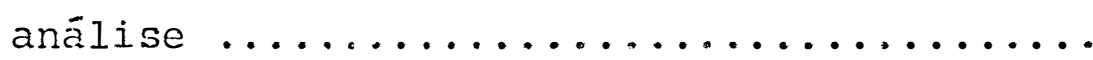

Tabela 19. Coeficientes de correlação ( $r$ ), teste de $F$ (F) e significância estatistica (s), entre a matéria vegetal seca e/ou o fósforo total na MVS de milho, com o fósforo orgānico do solo obtido por diferentes métodos de análí

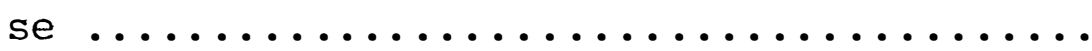


Tabela 20. Coeficientes de correlação (r), teste de F (F) e significância estatística (s), entre a matéria vegetal seca e/ou o fósforo total na MVS de feijoeiro, com o fósforo total do solo obtido por diferentes métodos de análi

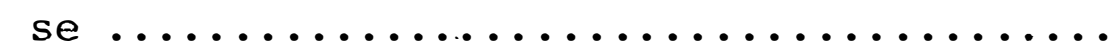

Tabela 21. Coeficientes de correlação $(r)$, teste de F (F) e significância estatística (s), entre a matéria vegetal seca e/ou o fósforo total na MVS de milho, com o fósforo total do so10, obtido por diferentes métodos de anäli-

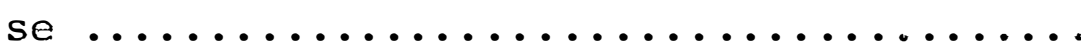

Tabela 22. Coeficientes de correlação $(r)$, teste de F (F) e significância estatística (s), entre a matéria vegetal seca e o fósforo total na MVS em feijoeiro, com os diferentes nives de fósforoađicionado ao solo, para cada

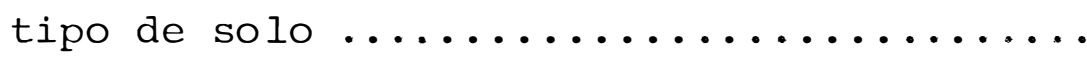

Tabela 23. Coeficientes de correlação (r), teste de $F$ (F) e significância estatîstica (s), entre a matéria vegetal seca, e o fósforo total na MVS em milho, com os diferertes niveis de fósforo adicionado ao solo, para cada tî po de solo ....................... 
Tabela 24. Coeficientes de correlação $(r)$, teste de $F$ (F) e significância estatística (s), entre a matéria vegetal seca e o fósforo total na MVS de feijoeiro, para cada nível de fósfo-

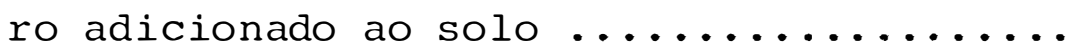

Tabela 25. Coeficientes de correlação $(x)$, teste de F (F) e significância estatistica (s), entre a matéria vegetal seca e o fósforo total na MVS de milho, para cada nível de fósforo a-

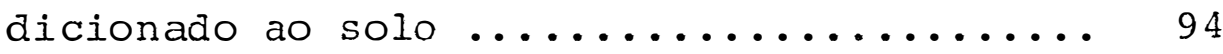




\section{LISTA DE FIGURAS}

pāgina

Figura 1. Feijoeiro em casa de vegetação aos 18 dias a pós o plantio, para diferentes níveis de fós foro adicionado ao solo, e para diferentes solos $\ldots \ldots \ldots \ldots \ldots \ldots \ldots \ldots \ldots \ldots$

Figura 2: Feijoeiro em casa de vegetação aos 40 dias a pós o plantio, para diferentes níveis de fós foro adicionado ao solo, e para diferentes

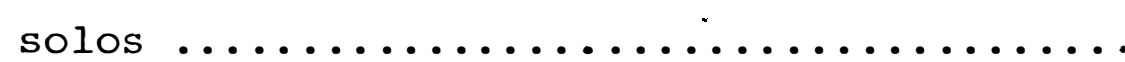

Figura 3. Milho em casa de vegetação aos 20 dias após o plantio, para diferentes níveis de fósforo adicionado ao solo, e para diferentes solos.

Figura 4. Milho em casa de vegetação aos 35 dias apös o plantio, em diferentes solos, e para os ni veis $\mathrm{P}_{0}$ e $\mathrm{P}_{1}$ de fósforo adiciorado ao solo.

Figura 5. Milho em casa de vegetação aos 35 dias após o plantio, em diferentes solos, e para os ní veis $\mathrm{P}_{2}$ e $\mathrm{P}_{3}$ de fósforo adicionado ao solo. 


\section{LISTA DE GRAFICOS}

$\underline{\text { pāgina }}$

Gráfico 1. Fósforo solúvel nos diferentes solos, por diferentes métodos de análise ..........

Gráfico 2. Fósforo orgânico nos diferentes solos, por diferentes métodos de análise ......

Gráfico 3. Fósforo total nos diferentes solos, por diferentes métodos de análise ..........

Gráfico 4. Matéria vegetal seca produzida pelo feijoeiro, para diferentes níveis de fósforo adicionado, e nos diferentes solos ......

Gráfico 5. Fósforo total na MVS do feijoeiro, para diferentes níveis de fósforo adicionado e nos diferentes solos ..............

Gráfico 6. Matéria vegetal seca produzida pelo milho, para diferentes níveis de fósforo adicionado, e nos diferentes solos ..........

Gráfico 7. Fósforo total na MVS de milho, para diferentes níveis de fósforo adicionado,e nos

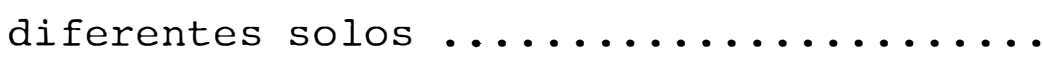


RESUMO

EXTRAÇAO DO FÓSFORO SOLUVEL, ORGÃNICO E TOTAL EM SOLOS DO ESTADO DE SATO PAULO POR DIVERSOS METODOS QUIMICOS, E DISPONIBILIDADE DESTE ELEMENTO UTILIZANDO O FEIJOEIRO (Phaseolus vulgaris, L.) E MILHO (Zea mays, L.)

\section{Autor: ALFREDO JOSE LOPEZ PEREZ}

Orientador: Prof. Dr. ANDRE MARTIN LOUIS NEPTUNE

Foram estudados diferentes extratores químicos para fósforo solúvel, fósforo orgânico e fósforo total, em cinco solos do Estado de São Paulo: Areia Quartzosa; Podzólico Vermelho Amarelo, variação Laras; Latossolo Roxo; Podzólico Vermelho Amarelo, variação Piracicaba e Terra Roxa Extrutu rada.

Foram também estudadas as respostas a quatro níveis de fósforo aplicado ao solo, nos cinco solos já mencio nados, utilizando o feijoeiro (Phaseolus vulgaris L.) e milho (Zea mays L.), cultivados em casa de vegetação.

Fizeram-se as correlações pertinentes, e as se guintes conclusões foram tiradas:

1. Os melhores extratores para $\mathrm{P}$ solúvel foram ○ $\mathrm{H}_{2} \mathrm{SO}_{4} 0,05 \mathrm{~N}$ (Método do IAC) e $\mathrm{H}_{2} \mathrm{SO}_{4} 0,025 \mathrm{~N}+\mathrm{HC}$ J. 0,005 N (Método de Mehlich). 
2. No P orgânico os extratores foram equivalen tes.

3. Para o P total, os melhores métodos foram os de Sommers e Nelson e o de Jackson.

4. Tanto no milho, como no feijoeiro, houve resposta significativa ao $\mathrm{P}$ adicionado ao solo.

5. A utilização efetiva do fósforo pelas duas culturas, foi baixa.

6. As melhores correlações do $\mathrm{P}$ solūvel com a matéria vegetal seca e o $\mathrm{P}$ total na MVS, nas duas culturas, fo ram com os extratores $\mathrm{H}_{2} \mathrm{SO}_{4} 0,05 \mathrm{~N}$ (IAC) e $\mathrm{H}_{2} \mathrm{SO}_{4} 0,025 \mathrm{~N}+\mathrm{HCl}$ $0,05 \mathrm{~N}$ (Mehlich) $(r=0,94 * *)$.

7. Os dois extratores usados para o P orgânico deram correlações similares com a matéria vegetal seca $\&$ o $P$ total na MVS para as duas culturas $(r=0,69 *)$. 
EXTRACTION OF SOLUBLE, ORGANIC AND TOTAL PHOSPHORUS

IN SOILS OF THE SÃO PAULO STATE, BRAZIL, AND AVAILABILITY OF THIS ELEMENT, USING BEAN PLANTS (Phaseolus vulgaris, L.) AND CORN (Zea mays, L.)

Author: ALFREDO JOSE LOTPEZ PEREZ

Adviser: Prof. Dr. ANDRE MARTIN LOUIS NEPTUNE

Various extractions methods for soluble P, organic P and total $\mathrm{P}$, were compared on five soils of the State of São Paulo, Brazil, namely: a. sandy quartz (Entisol), b. red yellow podzolic, Lara variation (Ultisol); c. red-ocre latosol (Oxisol); d. red yellow podzolic, Piracicaba, variation (Ultisol); e. terra roxa estruturada (Alfisol).

On these soils, response to phosphorus fertilizer aḍed in different rates was studied, with potted bean plant (Phaseolus vulgaris L.) and corn (Zea mays L.).

According to the data, the following conclusions were drawn:

1. The best extractants for soluble $P$ were $\mathrm{H}_{2} \mathrm{SO}_{4} 0.05 \mathrm{~N}$ (IAC method) and $\mathrm{H}_{2} \mathrm{SO}_{4} 0.025 \mathrm{~N}+\mathrm{HCl} 0.05 \mathrm{~N}$ (Mehlich method). 
2. For removing and measuring the organic P, the extractants were equivalents.

3. The chemical method of Sommers \& Nelson and that of Jackson were the best for the total $P$ in the soil.

4. There was a significant response to P added by both crops.

5. The efficient utilization of $P$, by both crops, was low.

6. These was a very good correlation $(r=0.94 * *)$ between the soluble $\mathrm{P}$ extracted by means of the Mehlich and IAC methous and Dry Vegetal Matter (DVM) and the $\mathrm{P}$ in this DVM.

7. Both extractants for organic $P$ gave good correlation with DVM and $P$ in this DVM ( $r=0.69 *)$. 


\section{INTRODUÇÃO}

o fósforo é um elemento carente na maioria dos solos do Brasil. O ânion fosfato liga-se com facilidade a cargas positivas livres - cátions, compostos ou partículas co loidais - formando os mais diversos sistemas, com diferentes graus de solubilidade, os quais contribuem para manter o equi líbrio do fôsforo na solução do solo.

De acordo com OLSEN e FRIED (1957), durante pe ríodo de rápido crescimento, o fósforo na solução do solo pode ser renovado, a partir da fase sólida, em dez ou mais vêzes ao dia em solos férteis, podendo atingir até 500 vêzes o teor inicial, porém, 0,1 ppm na solução do solo é suficiente (Seatz e Conney, 1963, citados por BRAGA e YANNER, 1968).

Como nem todo o fósforo presente no solo é con siderado disponível para as plantas, diferentes métodos têm sido empregados para medir a capacidade de um solo em suprir 
com este elemento as necessidades do vegetal; tais métodos po dem ser químicos, biológicos ou microbiológicos, com ou sem auxílio de isótopos marcados.

Sabe-se que o método biológico é o mais apropriado, porque a própria planta serve como indicadora de suas necessidades. Como não é possível o seu uso em análise de ro tina, então utilizam-se os métodos químicos, devido à facilidade, rapidez e economia com que se pode obter um diagnóstico (IVANOV, 1970). O extrator ideal seria aquêle que levasse em conta, além das características da planta, no que diz respeito ao seu ciclo vegetativo, as suas exigências em nutrientes e a sua capaciadade genética, entre outros (CATANI et alii, 1955).

o conteüdo de fósforo total ná maioria dos solos minerais varia entre 0,02 a $0,5 \%$ (JACKSON, 1964). Este po de se subdividir em duas frações principais: uma inorgânica que inclui principalmente fosfatos complexos de Al, Fe e Ca, a qual por sua vez se subdivide em uma parte solúvel em extra tores químicos, e uma insolúvel, e outra parte orgânica.

No estudo de fertilidade de solo, não hà um conceito definido quanto a preferência do vegetal por determi nada forma química de um nutriente. Os extratores quimicos utilizados para medir o teor "disponivel" do nutriente o fazem de maneira empírica, não distinguindo do conjunto de sistemas presentes no soló, aquelas formas preferidas pelo vege- 
tal.

A análise de fósforo solúvel por dois métodos pode apresentar correlação entre si em um grupo de solos : e não em outro. No entanto, a quantidade de trabalhos técnicos sobre comparação entre extratores químicos, para a determinação de fósforo solúvel, e testes de avaliação em casa de vege tação ou campo, cresce continuamente, sugerindo que, de forma geral, a melhor técnica de extração ainda não existe (CHANG, 1965).

A função do fósforo orgânico no solo é geralmente esquecida, provavelmente porque, em solos minerais cultivados, a maior parte do fósforo total está sob forma inorgâa nica. Acredita-se que a contribuição do fósforo orgânico no aproveitamente da planta é pequeno nos solos de regiões tempe radas (RUSSELI, 1973), embora esta possa ser significativa em solos de regiões tropicais (WILLIAMS, 1967).

As principais formas de fósforo orgânico no só. 10, são as seguintes: Ácidos Nucleicos, Fosfato de Inositol e Fosfolipídeos. No entanto, existem fosfoproteínas e fosfoaçú cares, tais como Glucose-1-Fosfato, as quais se apresentam em quantidades menores a 1\% do fósforo orgânico (ANDERSON, 1967).

Em referência ao fósforo orgânico e fósforo tọ tal, os trabalhos feitos coxrelacionarido a quantidade de fós foro no solo, com a real absorção do mesmo pela planta, tem 
sido poucos.

Pelo exposto, o presente trabalho, conduzido em vasos em casa de vegetação, teve como objetivo, estabelecer correlações entre as classes de fósforo: solúvel, orgânico e total, em cinco solos do Estado de são Paulo, em função dos extratores empregados, com a quantidade de Matéria Vegetal Seca, e de Fósforo Absorvido pelas culturas de Feijoeiro (Phaseolus vulgaris L.) variedade Iguaçu, e Milho (zea mays L.) variedade Piranão. 
A maior parte dos solos das regiões tropicais e subtropicais possuem um nivel muito baixo em fósforo disponivel. Por isso os rendimentos das culturas são geralmente muito baixos, a menos que se apliquem fertilizantes fosfatados.

De acordo com CATANI (1947), os solos do Estado de São Paulo são realmente pobres em fósforo. Verificou-se pelos seus estudos, que a Terra Roxa Legitima é a mais rica, vindo depois os solos da formação Corumbataí.

VIEIRA (1971), trabalhando com solos do Estado do Pará, encontrou valores de fósforo total situados entre 0,01 a $0,15 \%$. PASQUAL e NEPTUNE (1971), encontraram teor até de $4 \%$ de fósforo total em uma Terra Roxa Estruturada do Estado de são Paulo. De fato os solos Terra koxa do Brasil, acusam uma quantidade consideravelmente mais alta de fósforo to- 
tal e inorgânico, do que aquêles solos altamente meteorizados (NEPTUNE, 1976).

Nem todo o fósforo do solo é disponível para as plantas. A proporção das diversas formas de fósforo e o pH do sistema, vão influenciar na atividade ou concentração de ions fosfato na solução do solo e, portanto, na disponibilidade aos vegetais (CATANI e BATAGLIA, 1968). Deduz-se então que, o conhecimento das diversas formas de fósforo ocorrendo em um solo, reveste-se de importância na análise química do mesmo como supridor do elemento às culturas.

Tem sido propostos diversos métodos para a determinação do fósforo total em solos. Os cois métodos mais comumente usados para a extração do fósforo total de solos são: a digestão com Åcido Perclórico $\left(\mathrm{HClO}_{4}\right)$ (SOMMERS e NELSON, 1972), e a fusão com Carbonato sódico $\left(\mathrm{Na}_{2} \mathrm{CO}_{3}\right)$ e posterior extração com Ácido sulfúrico concentrado $\left(\mathrm{H}_{2} \mathrm{SO}_{4}\right)$ (JACKSON, 1970).

A digestão com Ácido Perclórico pode dar resul tados algo baixos na ausência de $\mathrm{HF}$, o qual garante a destruí ção dos silicatos que contêm fosfatos minerais (SOMMERS e NEL SON, 1972; SYERS et alii, 1968). Por outro lado, o método de fusão com Carbonato sódico dá recuperação quantitativa de todas as formas de fósforo em solos, mas é tedioso e consome muito tempo (MATTINGLEY, 1965; SHERRELL e SAUNDERS, 1966; SYERS et alii, 1967, 1969). A diferença que pode aparecer en- 
tre os valores de fósforo total pelos métodos de fusão com carbonato de sódio, e digestão com ácido perclórico, pode ser atribuída ao fósforo não extraível pelo ácido perclórico.

DICK e TABATABAI (1977), preconizam um novo mé todo para a determinação do fósforo total, baseados na ebulição, até a secagem do solo, com NaBro, e a posterior extração do ortofosfato com ácido sulfúrico $1 \mathrm{~N}$, determinando fotocolo rimetricamente o fósforo extraído, pelo método de azul de molibdênio modificado (MURPHY e RILEY, 1962). CATANI e BATAGLIA (1968), usaram o método por ataque com ácidos clorídrico, Nitrico e Sulfúrico concentrados, na proporção 10:3:5, e posterior extração com água.

Diversos pesquisadores, relacionando o extrator químico com as formas inorgânicas do fósforo no solo, puderam identificar aquele que mais contribui ao teor disponivel deste extrator, e assim chegar à preferência do vegetal (KUZ'MICH e CHUPRIKOV, 1979; PEREZ MENDEZ et alii, 1978; FERREIRA et alii, 1978; ANDERSON, 1975; SA et alii, 1974). Deve-se acrescentar que os próprios extratores utilizados são mais específicos a um tipo de composto de fósforo, não impedindo que extraia também dos outros tipos, conforme apontam SMITH (1970) e PRATT e GARBER (1964), variando de solo para solo sua atividade química (FASSBENDER, 1966).

FASSBENDER et alii (1968), ressaltam que

a distribuição dos fosfatos de $\mathrm{Fe}$, Al e Ca, e a sua predominân- 
cia nos solos, depende do pH dos mesmos, do produto de solubi lidade dos distintos fosfatos, dos cátions presentes no solo e do grau de meteorização destes solos. Com o aumento do pH favorece-se a predominância dos fosfatos de $\mathrm{Ca}$, por outro lado, a meteorização e consequente acidificação dos solos, favo rece a predominância de fosfatos de $\mathrm{Fe}$ e Al.

o fosfato de $\mathrm{Fe}$ seria a forma dominante em solos mais intemperizados (latossolos), e naqueles menos intemperizados, a do fosfato de Ca (CHANG, 1965).

BALERDI et alii (1968), estudaram 104 solos na América Central, e verificaram que 75 mostraram predominância de P-Ca, e 29 P $-\mathrm{Al}$.

CATANI e BATAGLIA (1968), analisando o fracionamento do fósforo em 8 solos do Estado ce são Paujo e cao Estado do Paraná, obtiveram: P ocluido > P-Fe > P-Ca > F-Al. Os solos estudados apresentavam teor de cálcio muito alto.

SMITH (1970), em uma ampla revisão bibliográfi ca, concluiu que no fracionamento de fósforo em solos ácidos, cumpre-se que: $\mathrm{P}-\mathrm{Red}$. $>\mathrm{P}-\mathrm{Al}>\mathrm{P}-\mathrm{Fe}>\mathrm{P}-\mathrm{Ca}$.

CABALA e FASSBENDER (1970), analisando amostras de perfís de solos da Bahía, obtiveram que: P-Red. > P$\mathrm{Fe}>\mathrm{P}-\mathrm{Ocluido}>\mathrm{P}-\mathrm{Ca}>\mathrm{P}-\mathrm{Al}$, e verificaram que o fósforo orgânico contribuiu com 55 \% do fósforo totai. 
DUTRA (1973), estudando o fracionamento de fós foro numa topossequência de solos de Viçosa-MG, verificou que as formas dominantes foram P-Red. e P-orgânico.

BAHIA FILHO (1974), estudando solos de Minas Gerais analisou as formas de fósforo e encontrou: P-Red. > $\mathrm{P}-\mathrm{Fe}>\mathrm{P}-\mathrm{Al}>\mathrm{P}-\mathrm{Ca}$.

. KARIM e KHAN (1955), estudando solos do Paquitão, observaram que o P-Orgânico predominava em $\mathrm{pH}=4,6$, e que P-Al e P-Fe são predominantes em $\mathrm{pH}=5,6$.

DAHNKE et alii (1963), estudando solos de El Salvador, encontraram que nos solos jovens, a maior proporção de fósforo total foi encontrada como P-Orgânico, P-Disponível e P-Al, sendo que nos solos velhos predominavam o P-Ocluso e $\mathrm{P}-\mathrm{Fe}$.

PEREIRA e FARIA (1977), trabalhando no médio São Francisco, verificaram que o fósforo adicionado, após seis meses de incubação, se encontrava praticamente em formas solü veis, formando compostos de P-Al, P-Fe e P-Ca.

Acresce ainda à dificuldade de se definir estas predominâncias, a própria credibilidade que se dá à meto... dologia do fracionamento do fósforo segundo CHANG e JACKSON (1956). Diversas objeções e modificações tem surgido na lite ratura, muito bem apanhadas em SMITH (1970), pois em qualquer das formas ativas, levantam-se suposições de não espelharem 
os valores reais.

Na realidade, entre as comprovações de laboratório e as ocorrências nos solos, acontecem diferenças de difíceis explicações.

De uma forma geral, segundo a ampla literatura consultada a respeito, podem-se distinguir as seguintes formas de fósforo no solo:

P-Fe : que indicam predominância nos solos ácí dos.

$\mathrm{P}-\mathrm{Ca}$ : indicando predominância nos solos alcalinos.

$\mathrm{P}-\mathrm{Fe}, \mathrm{P}-\mathrm{Al}, \mathrm{P}-\mathrm{Ca}$ : indicando predominância em solos levemente ácidos a neu tros.

P-Fe, P-Ca : indicando mistura de solos, ou so los com adubações de fosfatos nativos.

$\mathrm{P}-\mathrm{Fe}, \mathrm{P}-\mathrm{Al}$ : indicando solos ácidos adubados com fosfatos solúveis.

Muitas pesquisas têm sido feitas a respeito de diferentes métodos de extração de fosfatos solúveis, através das quais se tem constatado que, um ou outro, para as con dições de solo específico de cada trabalho, deram a melhor es timativa do suprimento de fósforo. 
Destacam-se três tipos de extratores: os de ácidos fortes diluídos, desenvolvidos para solos ácidos; os alcalinos, desenvolvidos para solos alcalinos e/ou calcários, e os de efeito complexante, desenvolvidos para solos de neutros a ácidos, principalmente os fertilizaōos com fosfatos na turais. Todos têm suas vantagens e desvantagens, no entanto nenhum é universal.

Os extratores mais usados são cronologicamente, os seguintes:

- Ácido Cítrico (Dyer, 1894, em FRIED e BROES HART, 1967) .

- Agua, só ou saturada com $\mathrm{CO}_{2}$ (Bura, 1918, em MELSTED, 1967, Daubeny, 1945, en: JACKSON, 1970; HAGIN et alii, 1963)。

- Ácido Sulfúrico (tRUOG, 1930; MC LEAN et alii, 1955; CATANI et alii, 1955; SUSUKI et alii, 1963).

- Lactato de Amônio em Áciōo Acético (Egner, 1932, Riehm, 1942 e 1948, em FRIED e BROESHART, 1967) .

- Acetato de sódio em Ãcido Acético (Morgan, 1935 e 1941, em FRIED e BROESHART, 1967; PEECH e ENGLISH, 1944).

- Ácido Acético (Spurway, 1944, em SMIth e COOK, 1953). 
- Acido Clorídrico e Fluoreto de Amônio (BRAY e KURTZ, 1945).

- Acido Clorídrico e Acido Sulfúrico (MEHLICH, 1953) •

- Cloreto de Cálcio (Aslying, 1954, em HAGIN e HILLINGER, 1964).

- Resina Trocadora de Annions (AMER et alii, 1955; MOSEUR et alii, 1959; SIBBESEN, 1977).

- Hidróxido de sódio (Saunder et alii, 1956, em PICHOT e ROCHE, 1972).

- Carbonato diversos (GRUNES et alii, 1963; OL SEN et alii, 1954; FRIED e BROESHART, 1967).

- Acido Bórico, no método de eletrodiálise (PAY NE E HANNA, 1965).

- EDTA (FRIED e BROESHART, 1967; ALEXANDER e ROBERTSON，1972; SAHRAWAT, 1977).

Muitos autores vêm buscando correlações entre os extratores químicos e fósforo disponível para a planta através da matéria vegetal seca, ou pelo fósforo absorvido.

SMITH e COOK (1953), estudaram a correlação en tre a matéria vegetal seca produzida pelo trigo em casa de ve getação, e diferentes métodos de análise para fósforo "disponível", chegando a conclusão que o método de Bray P-1 deu a melhor correlação. 
.13

WARREN e COOKE (1962), estudando solos sob plantio de beterraba açucareira da Inglaterra e da Escócia, en contraram a melhor correlação entre a matéria vegetal seca e o método de análise, nos métodos que usam altos volumes de ácido sulfúrico diluído.

HAGIN et alii (1963), estudando solos de Israel, com ervilhas, em casa de vegetação, não encontraram cor relações significativas com os métodos de Olsen; Bray P-1 e Acido Citrico diluído.

JACKSON et alii (1964), encontraram que o méto do de olsen foi o menos afetado pelo pH do solo, servindo por tanto, para solos ácidos e calcários. Entre os métodos estudados encontraram melhor correlação com alfafa en condições de campo, e depois, aveia e trevo em casa de vegetação, na se guinte ordem: Olsen > Bray P-1 > Olsèn + Fluoreto de Amônio.

WILLIAMS e COOKE (1965), estudando a correlação entre matéria vegetal seca em nabo, batatinha e pastagem, encontraram que a melhor correlação foi com o extrator de 01sen.

DAZA e MULLER (1965), analisando diferentes so los da região tropical, por diferentes métodos, encontraram a melhor correlação significativa entre os métodos de Bray P-1 e Olsen. 
los sob plantio de cana-de-açúcar, encontraram correlação significativa entre a matéria vegetal seca da cana e os métodos de Bray P-1 e P-2, para solos podzolizados, mas não para outros solos diferentes.

KACAR et alii (1967), estudaram 62 amostras de solos com $\mathrm{pH}$ que variava de 5,4 a 7,7 , obtendo a seguinte pre cisão para diferentes métodos de análise: Bray P-2 > Kacar > Bray $\mathrm{P}-1$ > Olsen et a $i$ i > Bingham.

BALERDI et alii (1968), trabalhando com 104 so los da América Central em casa-de-vegetação, usando como plan ta indicadora o tomate, correlacionaram cinco métodos químicos com crescimento relativo, e obtiveram os seguintes coeficientes: Egner-Riehm (lactato de cálcio $0,02 \mathrm{~N}$; $\mathrm{pH}=3,8$; relação 1:50) $r=0,947$; Olsen, $r=0,870$; Mehlich, $r=0,848$; - Saunder, $r=0,340$. Egner-Riehm e Olsen foram inäicados para os experimentos de calibração.

FONSECA et alii (1968), trabalhando com micro parcelas de milho em 170 amostras da região cacaueira da Bahia, encontraram que o nível crítico para os métodos de Bray P-1 e Mehlich, foram 11 ppm para produção relativa de massa verde de milho de 60\%, e de $17 \mathrm{ppm}$ para uma produção de 75\%, com bons coeficientes de correlações.

HALM (1968), trabalhando com milho em diferentes solos, encontrou que o método de Bray $\mathrm{P}-1$ apresentou alta 
significância com solos neutros, o método de Bray P-2 com solos ácidos e neutros, e o método de olsen para solos ligeiramente ácidos ou alcalinos.

OKE (1970), trabalhou com 15 solos e com 17 ex tratores diferentes, encontrando a maior correlação $(r=0,660)$ entre a quantidade de fósforo no milho e o fósforo solúvel, usando ácido sulfúrico $0,01 \mathrm{~N}$ como extrator do fósforo do so10.

CABALA e FASSBENDER (1970), trabalhando em casa de vegetação, com oito solos do sul da Bahia, e usando sor go como planta indicadora, encontraram correlação com a produ ção de matéria vegetal seca na seguinte ordem: Olsen > Truog $>$ Egner-Riehn > Mehlich.

HERNANDO et alii (1970), trabalhando com vinte solos da Espanha, em casa de vegetação, comparando fracionamento de fósforo e fósforo "disponível", encontraram correlação entre a absorção de fósforo e o fósforo "disponível" pelo trigo: var. Mara, e o extrator $\mathrm{H}_{2} \mathrm{SO}_{4} 0,5 \mathrm{~N}$.

VELAYTHAM e JAIN (1971), afirmaram que o "extrator ideal" para um nutriente deveria repetir a extração pa drão de planta dunante todo o período de crescimento. Seus es tudos foram em condições de campo, e os resultados preliminares foram com o fósforo, extraído pelo método de olsen, e utí lizaram o solo Coimbatore da India. O arroz extraiu de modo 
semelhante ao método de olsen com pH modificado para 8,2 .

VIDOR e FREIRE (1971), utilizaram três solos de Rio Grande do Sul, o extrator Mehlich e soja em condições de campo usando como planta indicadora, medindo-se a pro dução de grãos. Encontraram para os solos argilosos o nível crítico de 8 a $10 \mathrm{ppm}$ de $\mathrm{P}$, e para solo franco argiloso, o ní vel critico de 20 a 25 ppm de P.

ANGHINONI A BOHNEN (1972), estudando 40 solos do Rio Grande do Sul, compararam quatro métodos químicos em casa de vegetação e usaram como planta teste o sorgo, através do $\mathrm{P}$ absorvido pela planta. Todos os métodos mostraram-se eficientes, mas o extrator de Mehlich foi o que melhor se correlacionou com a absorção de fósforo pelo sorgo, e o de bray e Kurtz modificado $\left(\mathrm{NH}_{4} \mathrm{~F} 0,1 \mathrm{~N}+\mathrm{HCl} 0,1 \mathrm{~N}\right)$ foi $\circ$ que mais ex traiu fósforo.

TORRES e ORTEGA (1972), trabalhando em casa de vegetação com alface, em 10 solos do México, encontrou a melhor correlação entre $\circ \mathrm{P}$ extraído pela planta, e O P extraído do solo, com os métodos de Bray P-1 e Peech-Morgan.

BRAGA e DEFELIPO (1972a, b), trabalhando com 9 solos sob vegetação de cerrado no Triângulo Mineiro, verifica ram que o fósforo "disponível" obtido pelos diversos extratores, correlacionou com a matéria vegetal seca produzida por painço. Os extratores usados foram os de Mehlich, Bray P-1, 
Bray $\mathrm{P}-2$ e Olsen.

CABALA e SANTANA (1972), comparando extratores químicos para fósforo "disponível" em 10 solos da Bahia, encontraram que as quàntidades de fósforo extraídas estão na se guinte ordem: Truog > Olsen modificado > Olsen > Egner-Riehm $>$ Mehlich.

FOLE e GRIMM (1973), verificaram que o método de Bray e Kurtz modificado extraiu quase duas vêzes mais fósforo adicionado para a cultura de soja, do que o método da re sina, que extraiu semelhantemente ao de Mehlich. Quando ao fósforo residual (cultura anterior $=$ trigo), o de Mehlich extraiu menos.

DALAL (1973), encontrou que a quantidade de fósforo extraido com $\mathrm{NaOH} 0,25 \mathrm{M} / \mathrm{Na}_{2} \mathrm{CO}_{3} 0,1 \mathrm{M}$, correlacionou altamente $(r=0,828)$ com o fósforo extraído pelo trigo em ca sa de vegetação.

WALMSLEY e CORNFORTH (1973), usando 155 solos da India, encontraram que o método de olsen et alii foi o que melhor correlacionou a quantidade de fósforo extraída pelo mi lho, e o fósforo "disponível" no solo.

SA JUNIOR et alii (1974), trabalhando com miIho em casa de vegetação, em solos da "Zona Litoral-Mata" de Pernambuco, e utilizando diferentes extratores, encontraram que $\circ$ de melhor precisão foi $\circ$ de Hawaii ( $\mathrm{HCl} 0,5 \mathrm{~N})$. 
BAHIA FILHO (1974), trabalhando com 20 latosso los de Minas Gerais, e aveia como planta teste, em casa de ve getação, comparou diversos métodos para extração do fósforo "disponível". O método de Bray P-1, embora tenha sido estatisticamente equivalente aos de Mehlich e olsen, foi indicado para os laboratórios de rotina devido a: a. maior facilidade no preparo da solução extratora; b. boa relação solo:solução, e c. maior amplitude de teores de fósforo.

TITTERINGTON e VARSA (1974), trabalharam com cinco solos do Rio Grande do Sul, tendo o sorgo como planta in dicadora, obtiveram, em casa de vegetação, a melhor correlação entre a produção de grãos e o método de Bray modificado ( $\left.\mathrm{HCl} 0,1 \mathrm{~N}+\mathrm{NH}_{4} \mathrm{~F} 0,1 \mathrm{~N}\right)$.

GONZÁLEZ e PEREZ (1976), trabalhando com solos com valor de pH menor a 7, e conteúdos de Ca menores a 1000 ppm, encontraram que a melhor correlação entre matéria vegetal seca de milho, e fósforo extraído do solo, foi com o méto do de Mehlich.

GONZÁLEZ et alii (1976), encontrou que a melhor correlação entre matéria vegetal seca de milho, obtida em casa de vegetação, e fósforo solúvel em solos de pH menor de 7, foi obtida com o método de Mehlich.

BRAGA et alii (1976), conduzindo sete ensaios com soja, em solos sob cerrado no Estado de Minas Gerais, em 
condições de campo, nos resultados do primeiro ano consideraram que os extratores de Bray P-2 e de Bray e Kurtz modificado, extraíram mais fósforo que o método de Mehlich, proporcio nando maior amplitude de valores.

PEREIRA e FARIA (1977), trabalhando com um ver tissol de pH 8, de Juazeiro no médio São Francisco, em casa de vegetação e usando milho como planta indicadora, obtiveram bóa correlação entre a produção de matéria vegetal seca, e os métodos de Bray P-1, Olsen et alii, Mehlich e com água.

ENWEZOR (1977), trabalhando com solos da Nigeria e milho como planta teste, encontrou a melhor correlação entre matéria vegetal seca, e fósforo "disponível", com o mêtodo que usa como extrator $\mathrm{NH}_{4} \mathrm{~F} 0,03 \mathrm{~N}$ e $\mathrm{HCl} 0,1 \mathrm{~N}$, sendo recomendado como método de rotira para a determinação de fósfo- ro "disponível" em solos ácidos da Nigéria.

RESENDE (1977), utilizando solos da Bahía e es tudando-os em várias profundidades, correlacionou as formas de fốsforo obtidas e o fósforo "disponivel" através dos métodos de Mehlich e Olsen mais fluoreto, e encontrou que este ú timo apresentou resultados mais constantes e representa meIhor a realidade, estudo apenas de laboratório.

$$
\text { DHILLON et alii (1977), trabalhando com solos }
$$
da. India, usando trigo e arroz como plantas teste em casa de vegetação, encontraram que a melhor correlação com referência 
ao fósforo absorvido, e ao crescimento vegetal, deu-se quando a extração no solo foi feita com o método de olsen et alii.

BITTENCOURT et alii (1978), trabalhando com di ferentes solos tratados com $N, K$ e diferentes níveis de $P$, usando cana-de-açúcar como planta teste, e comparando os resultados na determinação de fósforo em solo, com o crescimento da cana em campo, encontraram que o melhor método é aquele que usa ácido sulfúrico $0,5 \mathrm{~N}$ como extrator, com relação solo :solução 1:10, e 15 minutos de tempo de agitação.

A porcentagem da fração orgânica no fósforo to tal é variável e situa-se entre os valores de 2,6 a $86 \%$. Assim, por exemplo, BLACK e GORING (1953) indicam que esta fração varia entre 2,6 a 75\% do fósforototal. Em 1961, BREMNER e Ho enfatisam a importância quantitativa co fôsforo orgânico em muitos solos, indicando que pode alcançar até $50 \%$ do $\mathrm{P}$ total. WELLS e SAUNDERS (1860), confirmaram esses resultados depois de pesquisarem 136 amostras de solos de Nova Zelandia, nos quais a porcentagem foi de 13 a $79 \%$, com uma média de $54 \%$. OMOSTOSO (1971) estima que em plantações de cacaueiro de Nigé ria, a porcentagem varia de 21 a $74 \%$. KAILA (1963), encontrou em 213 amostras de solos, que o P orgânico contribui com 17 a $68 \%$ do fósforo total. MORTENSEN e HINES (1964), encontraram um limite superior de $80 \%$ e, em alguns trabalhos, espe cialmente em solos de clima tropical, como os de AWAN (1964) e de FRIEND e BIRCH (1960), apontam valores que chegam até $86 \%$ do fósforo total. 
As moléculas orgânicas dos ácidos nucleicos, as quais participam da vida da célula, não existem livres na natureza, a menos que seja destruída a membrana celular. Elas apresentam duas formas: RNA e DNA, ambos formados por uma cadeia de nucleotídeos contendo cada uma delas o açúcar pentose, a base púrica ou pirimídica e funções orotofosfato. ANDER SON (1970), isolou duas formas de difosfato de pirimidina em extrato ailcalino do solo, descubrindo assim a presença no solo da estrutura unitária caracteristica do DNA. Em complemen to a isso, ADAMS et alii (1954), ANDERSON (1961) e ISLAM e AM MED (1973), estimaram que a quantidade de ácidos nucleicos corresponde a 7\% do fósforo orgânico total no solo.

Os ésteres fosfóricos do inositol representam mais de 50\% do fósforo orgânico total do solo, em estimativas dadas por ANDERSON (1967), COSGROVE (1963) e MCKERCHER (1968).

o. âcido fítico ou hexafosfato de inositol, e seus sais hidratados de sódio, são muito solúveis. Por outro lado, os sais de $\mathrm{Al}, \mathrm{Fe}, \mathrm{Ca}$ e Mg são insolúveis (ANDERSON, 1963). As duas formas anteriores, usualmente chamadas fitina, são na realidade os mais comuns em plantas adultas. Numerosos isômeros tem sido isolados do solo por CONSGROVE $(1963,1967$, 1972), MARTIN (1964), MCKERCHER (1968) e L'ANNUNZIAIA (1975). A fitina pode se hidrolisar no solo por bactërias, liberando fosfatos sob formas disponíveis para as plantas (HANCE e ANDERSON, 1963). 
Os fosfolipideos mais frequentemente encontrados no solo são: Lecitina (Fosfatidilcolina), Fosfatidiletanolamina e Fosfatidilcerina (STRICKLAND, 1975). Estas formas, as quais são extraíveis com solventes orgânicos (éter, clorofórmio e benzeno), constituem entre 0,5 e 7\% do fósforo orgânico do solo (ANDERSON e MALCOM, 1974).

Num estudo do movimento do fósforo em solos calcários, HANNAPEL et alii (1964a, b) consideraram que 90\% das formas que se movimentam através do perfil são frações or gânicas; eles também concluiram que os microorganismos tem um papel predominante neste aspecto. FARDEAU et alii (1968), en contraram que as plantas são capazes de obter uma importante parte de seu fósforo por absorção do fitato de sódio aplicado como fertilizante. FURUKAWA e KAWAGUCHI (1969), estabeleceram que a incubação a $40^{\circ} \mathrm{C}$ do solo sob cultivo de arroz, redu zia em 20\% o conteúdo de fósforo orgânico, e concluiram que a hidrólise da fitina é estimulada pela inundação do solo . SZEMBER (1960), encontrou que 50\% dos microorganismos na zona das raizes contém fitases.

Por outra parte, KOTELEV et alii (1953, 1960), os quais estudaram respectivamente 35 espécies de bactérias e 32 espécies de fungos do solo, estimaram que todos eles contém nuclease, mas pouco fitase. BIRCH (1961), comparou a decomposição de plantas novas e velhas, e irformou que a minera lização microbiológica é mais ativa em plantas novas, e que 
708 do fósforo encontra-se na forma ácida solúvel, e 308 na forma ācida insolúvel. JACQUIN et alii (1968), encontraram que a proporção de fósforo orgânico formado, variava com a presença ou não de $\mathrm{Ca}$, Al e Fe no meio nutritivo.

JOSHI e SAXENA (1972), afirmaram que a "humina", a fração não extraível da matéria orgânica, não continha fósforo. SWIFT e POSNER (1972), assinalaram que as moléculas mais pesadas dos ácidos húmicos tem o maior conteúdo de fósfọ ro.

A proporção elevada de fósforo orgânico não se deve a grandes quantidades de fósforo orgânico presente, mas sim as pequenas reservas de fósforo total em muitos solos tro picais (BORNEMISZA, 1966).

Estudos recentes indicam que parte deste fós fo ro orgânico, especialmente suas frações mais importantes são, até certo ponto, diretamente disponíveis para as plantas, aumentando assim a importância do conhecimento detalhado desta fraçãó de fósforo (BOWER, 1949; MORTENSEN e HINES, 1964; DORMAAR e WEBSTER, 1963; WILLIAMS e WALKER, 1967; HONG e YAMANE, 1975; TATE; 1979).

Apesar de sua contribuição de considerāvel importância, existem poucos trabalhos na América Latina que se dedicam ao estudo desta categoria de fósforo (AWAN, 1964; CATANI et alii, 1957; DAHNKE et alii, 1964). 


\section{MATERIAIS E METODOS}

3.1. Solos

Foram utilizados cinco solos do Estado de Säo Paulo, a saber:

a. Terra Roxa Estruturada (TRE), proveniente do Município de Botucatu;

b. Podzólico Vermelho Amarelo, variação Piraci caba (PVp), proveniente do Município de Piracicaba;

c. Latossolo Roxo, sērie Iracema (LR), proveniente do Município de Iracema;

d. Podzólico Vermelho Amarelo, variação Laras (PVls), proveniente do Município de Corumba tai;

e. Areia Quartzosa $(A Q)$, cerrado, proveniente do Município de Brotas. 
As letras entre parênteses representam os códị gos de cada solo, que serão utilizados no texto e nas tabelas. Os solos anteriores são classificados, ao nivel de Ordem, segundo o Soil Taxonomy, da forma seguinte:

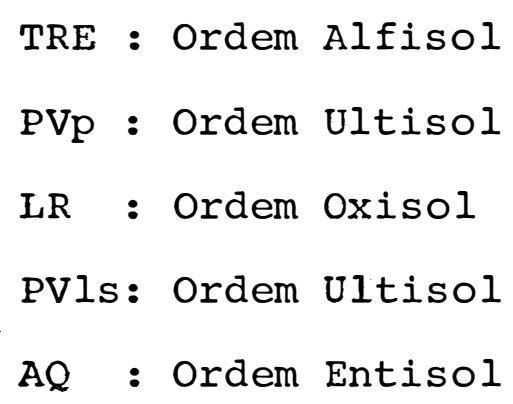

Todos os solos for am coletados a uma profundidade entre 0 e $25 \mathrm{~cm}$. Postos a secar ao ar. Amostras compos tas fora, peneiradas (Peneira 18) e pequenas porções däs mesmas foram tomadas para análise química, análise granulométrica e determinação de umidade, no Laboratório de Solos, do Departamento de Solos, Geologia e Fertilizantes da ESALQ.

3.2. Métodos de Anālise Química pará Fósforo

Para os diferentes solos, utilizaram-se os seguintes métodos de análise química para cada classe de fósforo: 
3.2.1. Fósforo total

3.2.1.1. Digestão com Ãcido Perclórico $\left(\mathrm{HClO}_{4}\right)$ concentrado (SOMMERS e NELSON, 1972).

3.2.1.2. Fusão com Carbonato de sódio $\left(\mathrm{Na}_{2} \mathrm{CO}_{3}\right)$ e posterior extração com Ácido Sulfúrico $\left(\mathrm{H}_{2} \mathrm{SO}_{4}\right)$ concentrado (JACKSON, 1970) .

3.2.1.3. Digestão com ácidos Clorídrico (HCl), Nítrico $\left(\mathrm{HNO}_{3}\right)$ e Sulfúrico $\left(\mathrm{H}_{2} \mathrm{SO}_{4}\right)$ (CATANI e BATAGLIA, 1968).

3.2.2. Fōsforo Solūvel

3.2.2.1. Método de Bray P-1 (BRAY e KURTZ, 1945), com solução extratora de Fluoreto de Amônio $\left(\mathrm{NH}_{4} \mathrm{~F}\right) \quad 0,03 \mathrm{~N}$ e Ácido Clorídrico (HCl) $0,025 \mathrm{~N}$, com relação solo: extrator 1:20 e 5 minutos de tem po de agitação.

3.2.2.2. Método de Bray P-2 (BRAY e KURTZ, 1945), com solução extratora de Fluo- 
reto de Amônio $\left(\mathrm{NH}_{4} \mathrm{~F}\right) \quad 0,03 \mathrm{~N}$ e Ácido Clorídrico (HCl) $0,1 \mathrm{~N}$, com relação solo: extrator 1:20, e tempo de agitação de 1 minuto.

3.2.2.3. Método de Mehlich (MEHLICH, 1953), com solução extratora de Ãcido Sulfúrico $\left(\mathrm{H}_{2} \mathrm{SO}_{4}\right) \quad 0,025 \mathrm{~N}$ e Åcido Clorídrico (HCl) $0,05 \mathrm{~N}$, sendo a relação solo: ex trator de $1: 20$, e o tempo de agitação de 5 minutos. Este método é conhecido também como Método da Carolina do Norte.

3.2.2.4. Método äo Instituto Agronômico, Campi nas, SP (CATANI et alii, 1955), com solução extratora de Ãcido Sulfúrico $\left(\mathrm{H}_{2} \mathrm{SO}_{4}\right) 0,05 \mathrm{~N}$, relação solo: extrator de 1:20, e tempo de agitação de 15 minutos.

3.2.2.5. Método de Olsen (OLSEN et alii,1954), com solução extratora de Bicabornato de sódio $\left(\mathrm{NaCO}_{3} \mathrm{H}\right) \quad 0,05 \mathrm{M}$ a pH 8,5 , re lação solo:extratur 1:20, e tempo de agitação de 30 minutos. Foram adicio 
nadas 3 gramas de carvão livre de fós foro para cada extração.

3.2.3. Fōsforo orgānico

3.2.3.1. Método de extração com Acido Clorídri co ( $\mathrm{HCl}$ ) e Hidróxido de sódio $(\mathrm{NaOH})$, (MEHTA et alii, 1954).

3.2.3.2. Método de Ignição, e posterior extração com Ãcido Sulfúrico (SAUNDERS e WILIIAMS, 1954).

Em todos os casos, o fósforo foi determinado fotocolorimetricamente no aparelho de Klett-Summerson, a 660 $\mathrm{m} \mu$, pelo método do Azul Sulfomolíbdico, modificado por MURPHY e RILEY (1962).

3.3. Experiências em casa de vegetacão

Foram usadas duas espécies de plantas, uma leguminosa: Feijoeiro (Phaseolus vulgaris L.), variedade Iguaçū', e uma gramínea: Milho (Zea mays L.), variedade Piranão, as quais se cultivaram em vasos de 3 litros de capacidade, sen do que dos solos PVls, PVp e LR foram pesados $3 \mathrm{~kg}$, da TRE, 
$2,5 \mathrm{~kg}$ e da $A Q 4 \mathrm{~kg}$.

O experimento constou de quatro tratamentos com quatro níveis de fósforo, e trềs repetições para cada um dos tratamentos. Os níveis de fósforo foram os seguintes:

$$
\begin{aligned}
& \mathrm{P}_{0}: 0 \mathrm{~kg} \text { de } \mathrm{P}_{2} \mathrm{O}_{5} / \mathrm{ha}=0 \mathrm{ppm} \text { de } \mathrm{P} \\
& \mathrm{P}_{1}: 50 \mathrm{~kg} \text { de } \mathrm{P}_{2} \mathrm{O}_{5} / \mathrm{ha}=10,92 \mathrm{ppm} \text { de } \mathrm{P} \\
& \mathrm{P}_{2}: 100 \mathrm{~kg} \text { de } \mathrm{P}_{2} \mathrm{O}_{5} / \mathrm{ha}=21,84 \mathrm{ppm} \text { de } \mathrm{P} \\
& \mathrm{P}_{3}: 150 \mathrm{~kg} \text { de } \mathrm{P}_{2} \mathrm{O}_{5} / \mathrm{ha}=32,76 \mathrm{ppm} \text { de } \mathrm{P}
\end{aligned}
$$

A fonte de fósforo foi Superfosfato-simples, com $17,22 \%$ de $\mathrm{P}_{2} \mathrm{O}_{5}$ solúvel em água.

Cada vaso recebeu uma adubação básica $\mathrm{N}$ K. Os níveis de Nitrogênio e Potássio no plantio, para as duas culturas, foram de $60 \mathrm{~kg} \mathrm{~N} / \mathrm{ha}$ e $75 \mathrm{~kg} \mathrm{~K} \mathrm{~K}_{2} \mathrm{O} / \mathrm{ha}$.

A fonte de Nitrogênio foi Uréia com $45 \%$ de Nitrogênio, e a de Potássio foi Cloreto de Potássio com $60 \%$ de $\mathrm{K}_{2} \mathrm{O}$.

No Milho, foi aplicada uma dose suplementar de Nitrogênio, em cobertura aos 30 dias, correspondendo a $60 \mathrm{~kg}$ N/ha, usando-se como fonte Nitrato de Amônio com 33,5\% de Ni- 
trogênio.

Foram plantadas 5 sementes em cada vaso, fazen do-se o desbaste aos 7 dias, deixando três plântulas por vaso. Após um periodo de 60 dias, as plantas foram cortadas a $0,5 \mathrm{~cm}$ da superfície do solo, e postas a secar em estufa a $70^{\circ} \mathrm{C}$.

Posteriormente pesou-se a matéria vegetal até peso constante em três pesadas consecutivas, moendo-se posteriormente o material vegetal seco, em micro moinho Wiley, peneira no 20.

3.4. Fósforo Total na Matéria Vegetal Seca

Para determinar o fósforo totai na matéria vegetal seca (MVS), foram pesadas $500 \mathrm{mg}$ de MVS moida de milho e $250 \mathrm{mg}$ de MVS moida de feijoeiro, procedendo-se a digestão nítricoperclórica, e determinação posterior do fósforo pelo. método do Vanado-Molibdato (HESSE, 1971).

\subsection{Anālise Estatistica}

O experimento foi inteiramente casualizado,com quatro tratamentos e três repetições, para cinco solos diferentes, e duas culturas diferentes. Os cálculos foram feitos 
na calculadora Texas "TI Programmable 59", com unidade impres sora Texas PC-100C. As anālises de variância foram feitas conforme PIMENTEL GOMES (1970), e as provas de significância estatística, através do Teste de F. 
.32 .

4. RESULTADOS E DISCUSSÃO

4.1. Anālise Quĩmica e Mecànica de Solos

Os resultados das análises químicas feitas nos diferentes solos, estão apresentados na Tabela 1.

Segundo os Padrões de Fertilidade de solo do Instituto Agronômico, Campinas (ULTRAFERTIL, 1980), podem-se fazer as seguintes considerações.

Os solos $A Q$ e PVIs apresentam acidez mediana $e$ forte respectivamente; teores baixos de $\mathrm{C}_{0}, \mathrm{~K}^{+}, \mathrm{Ca}^{2+} \mathrm{e} \mathrm{Mg}^{2+}$, assim como níveis não toleráveis de $\mathrm{AI}^{3+}$.

Os solos LR e PVp, apresentam-se medianamente ácidos, sendo que $O \mathrm{LR}$ apresenta teores altos de $\mathrm{C} \%$, médio de $\mathrm{K}^{+}$, e alto de $\mathrm{Ca}^{2+}$ e $\mathrm{Mg}^{2+}$, sendo $\circ \mathrm{Al}^{3+}$ tolerável; $\circ$ PVp apre senta alto teor de $\mathrm{C}^{\circ}$, teores médios de $\mathrm{K}^{+}$e $\mathrm{Ca}^{2+}$ e alto teor 
teor de $\mathrm{Mg}^{2+}$, sendo $\circ \mathrm{Al}^{3+}$ tolerável.

A TRE apresenta acidez fraca, teores altos de

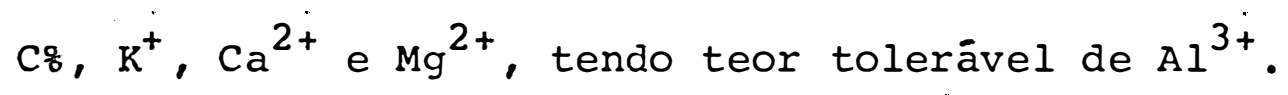

Os resultados das anālises granulométricas dos solos, assim como o seu conteúdo de umidade, estão apresentados na Tabela 2 .

Segundo estes dados, a classificação textural dos solos è a seguinte:

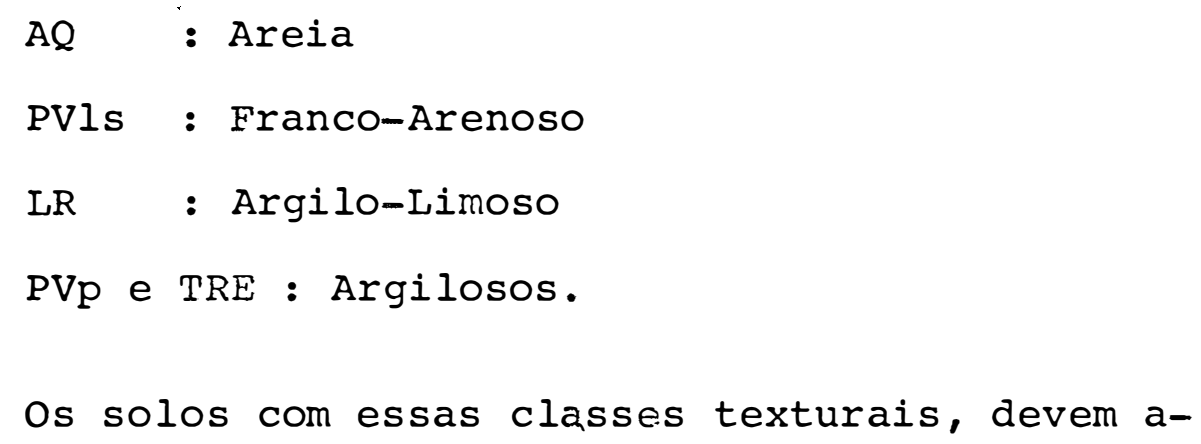

$A Q$ : baixa água disponivel para as plantas e excessiva drenagem interna.

PVls: baixa água disponível para as plantas, e excessiva drenagem interna.

LR : alta quantidade de água disponivel para as plantas, e drenagem interna suave.

PVp : alta quantidade de água disponivel para as plantas, e de suave a pobre drenagem interna. 


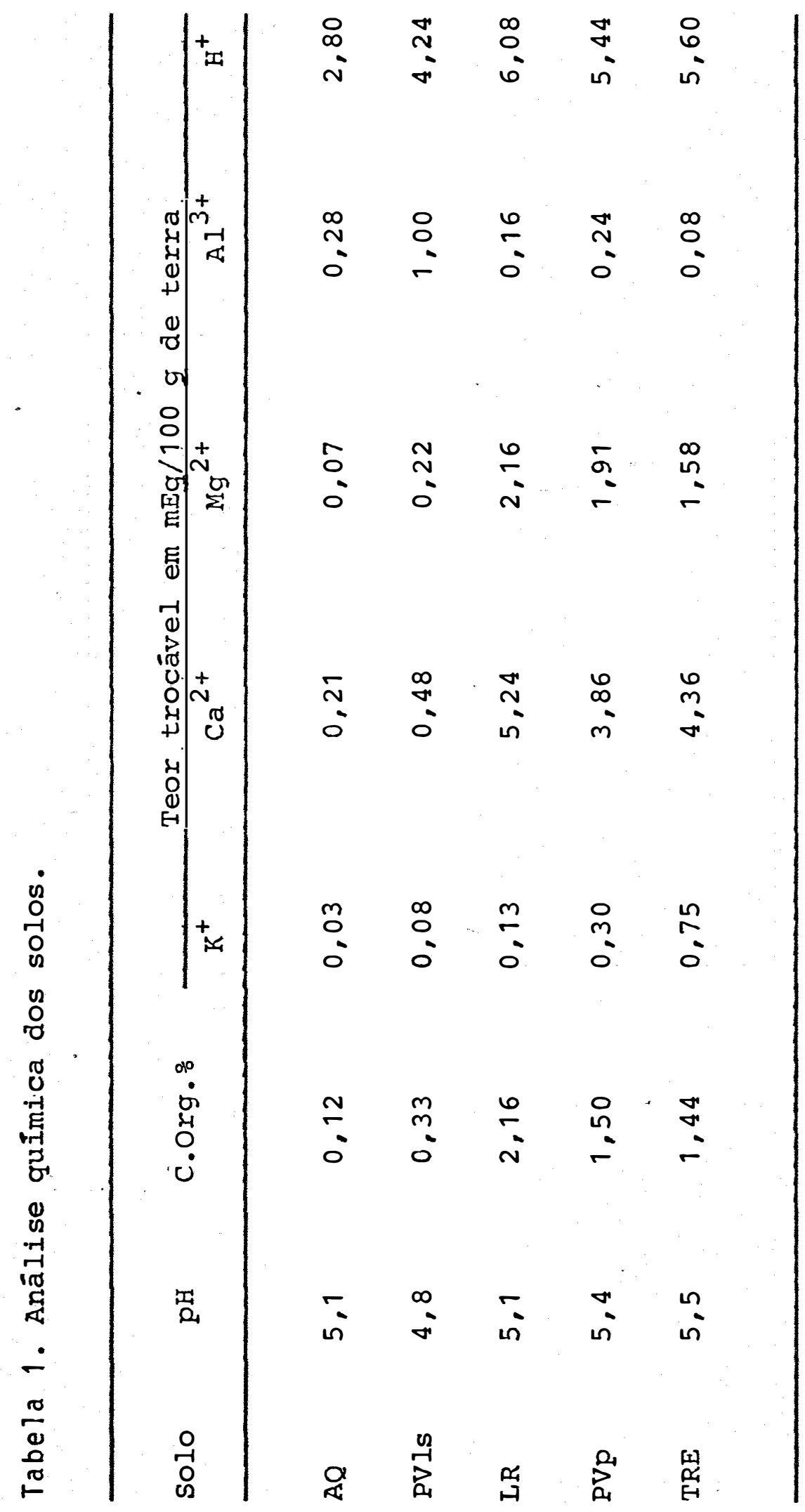


.35 .

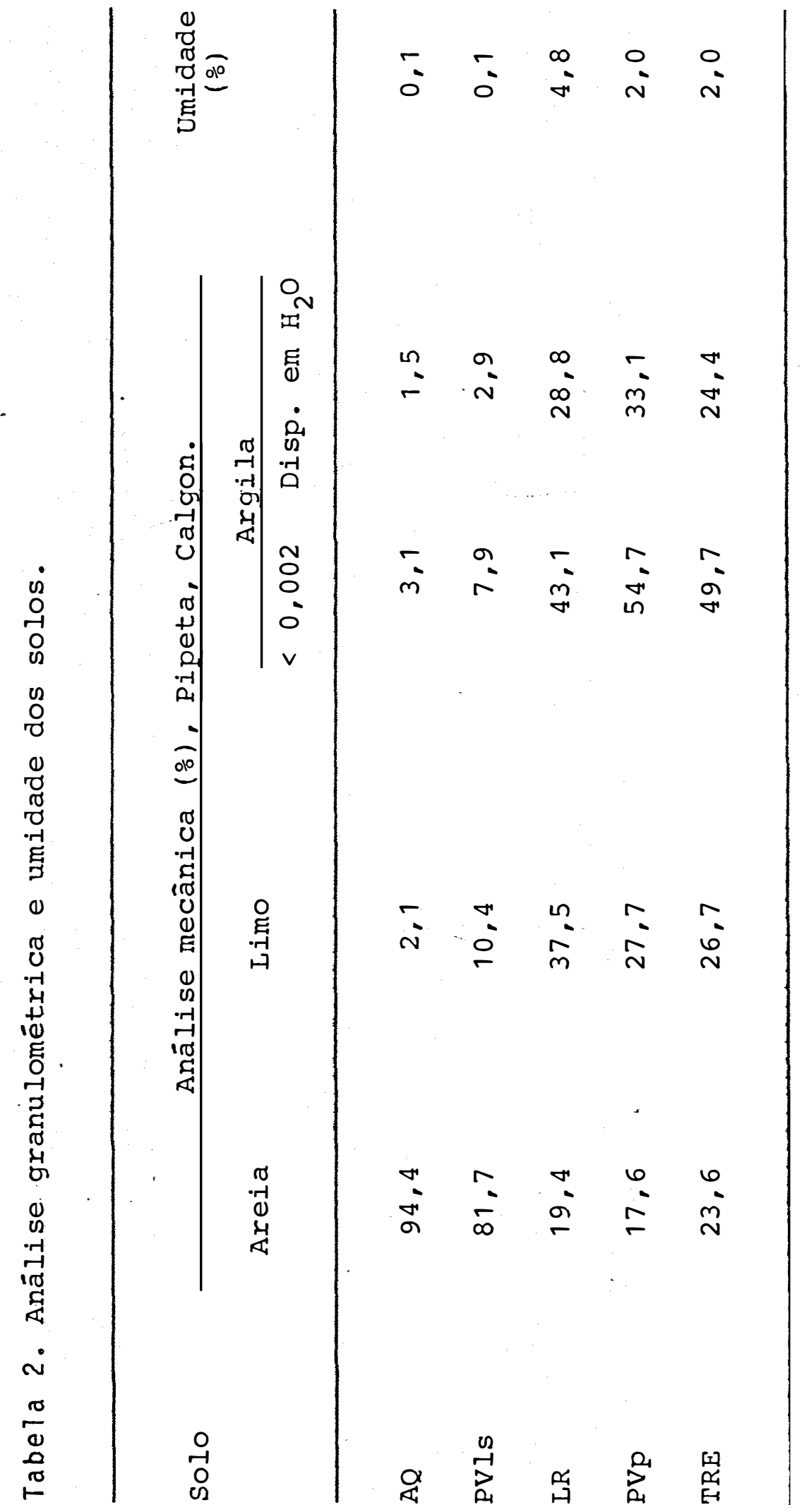


TRE : alta quantidade de água disponivel para as plantas, e de suave a pobre drenagem interna.

4.2. Anālises Quỉmicas para Fósforo em Solo

\section{4:2.1. Fósforo Solūvel}

Também é chamado de fósforo "disponível", o qual não é muito correto, já que a "disponibilidade" dada por um extrator nem sempre é igual a quantidade disponivel para a planta, pois a quantidade extraída por um método depende de muitas variāveis.

Os valores encontrados pelos diferentes métodos de análise propostos, estão na Tabela 3 .

Levando em consideração os resultados do método de análise para Fósforo Solúvel do IAC (CATANI et alii, 1955), e os Padrões de Fertilidade de Solo do Instituto Agronômico, Campinas, é possîvel classificar estes solos, segundo o teor de Fósforo Solúvel, na forma seguinte: AQ e LR, teores muito baixos; PVls e PVp, teores médios e TRE, teor alto de fósforo solúvel.

Independentemente de considerações posteriores, na $A Q$ O extrator mais enérgico foi o de Bray P-2 (Gráfico 1), 
seguido dos de Olsen, Mehlich, Bray P-1 e IAC, apresentando -se diferença estatística significativa ao nível de 1\% entre todos os métodos, mas não entre os métodos de Mehlich e Bray $\mathrm{P}-1$.

E de se notar, que na $A Q$ o método de Olsen ocu pou o segundo lugar. Isso pode ser devido a que, na $A Q$, tem-se um tẹor de argila muito baixo, pelo qual as interferênci as fotocolorimétricas são quase nulas.

No PVls, o extrator mais enérgico foi o de IAC (Gráfico 1), o qual não apresentou diferença significativa cam o de Mehlich. A continuação, em ordem decrescente, vem o de Bray P-2, Olsen, e por último o de Bray P-1 como o mais fra$\mathrm{co}$.

No LR, o extrator mais eficiente foi o de Bray P-2 (Gráfico 1), seguindo em ordem decrescente os de Bray P-1, Mehlich, IAC e Olsen. Apresentou-se diferença estatisticamen te significativa ao nível de $1 \%$ de probabilidade entre todos os métodos.

No PVp,o extrator mais enérgico foi o de Mehlich (Gráfico 1), seguindo em ordem decrescente os de Bray $\mathrm{P}-2$, IAC e Bray $\mathrm{P}-1$, os quais não apresentaram diferença significativa ao nível de $1 \%$ de probabilidade, e por último o de Olsen como o mais fraco.

Na TRE (Gráfico 1), o extrator mais enérgico 
.37 .

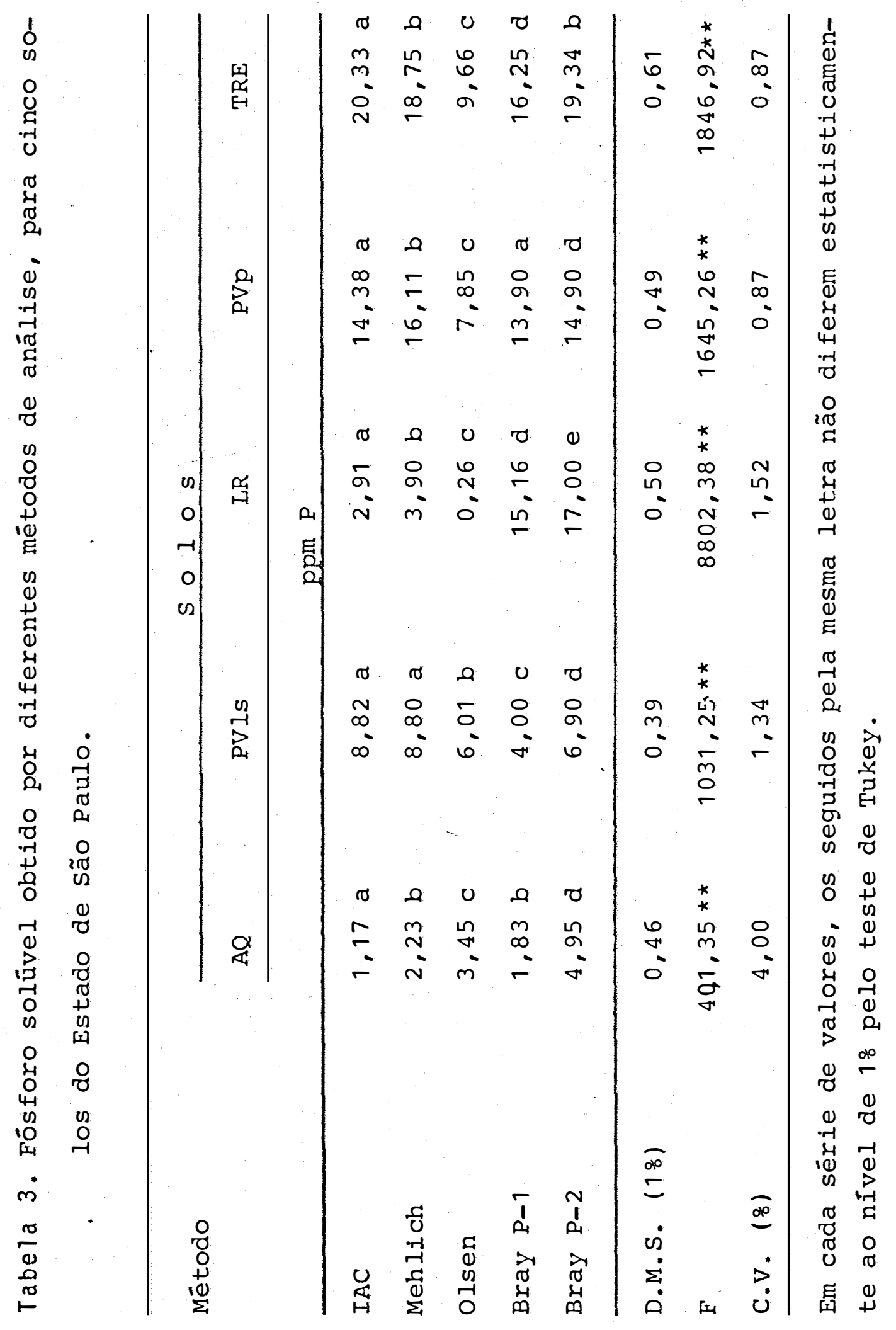


.39 .

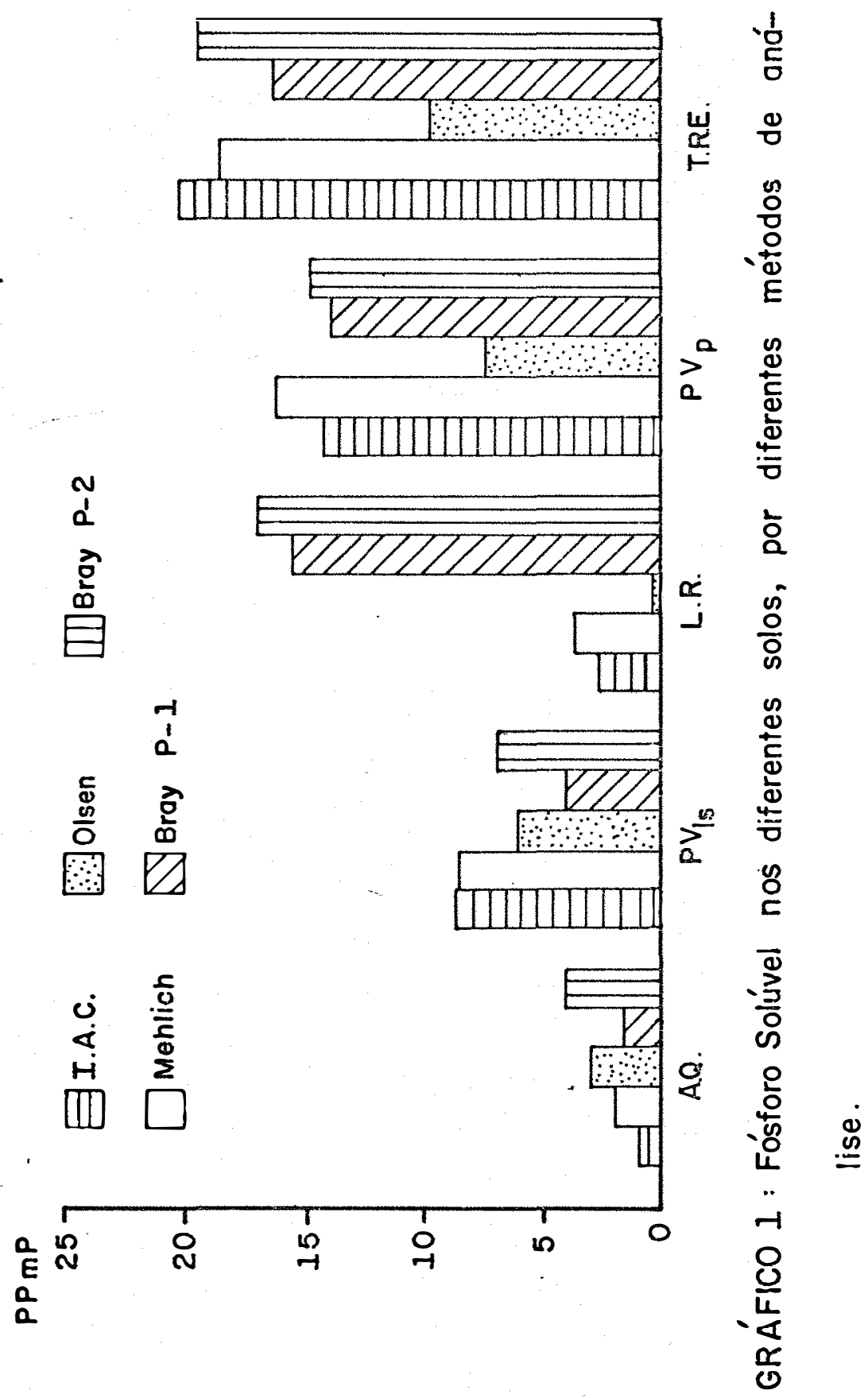


foi O do IAC, seguido dos de Mehlich e Olsen, os quais não apresentaram entre eles diferença estatisticamente significativa ao nível de 1 \% de probabilidade, seguido de Bray P-1 e por ültimo Olsen como o mais fraco.

Em resumo tem-se o seguinte para cada solo:

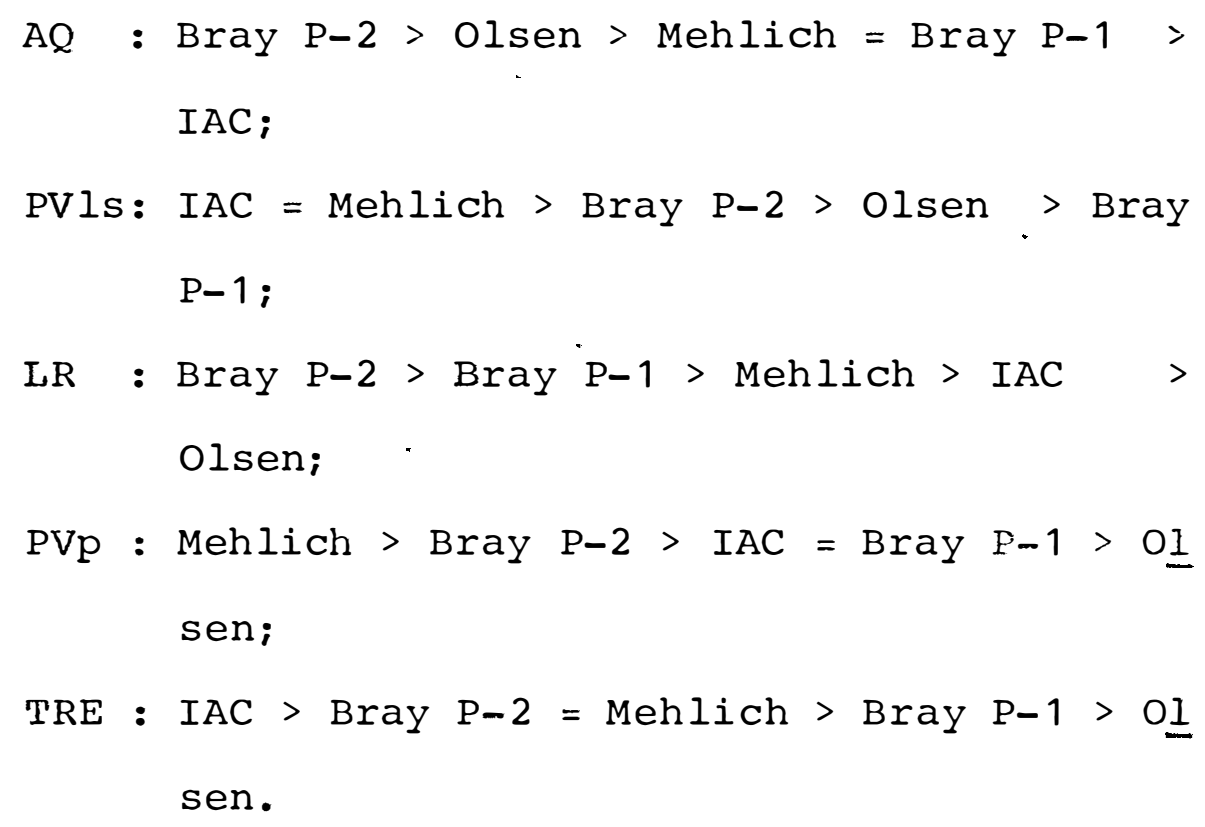

Dos resultados anteriores pode-se perceber que, de forma geral, os métodos que apresentaram maior poder extra tor, são aqueles com soluções de ácidos fortes (IAC, Mehlich), e o que usa uma mistura de fluoreto e ácido diluído (Bray P$-2)$.

Os métodos de Bray P-1 e Bray P-2, mostraram-se eficientes, sendo as soluções extratoras relativamente límpidas. Estes métodos apresentam fluoreto de amônio nas so luções extratoras, e o ion fluoreto pode interferir no desen- 
volvimento da cor na reação do azul de Molibdênio, como mostra o trabalho de KURTZ (1942); tal fato também foi lembrado por JACKSON (1970). BIASI (1978), verificou em dois solos de Santa Catarina, que a adição de ácido bórico aumentou o teor de $\mathrm{P}$ de $2 \%$ a $4 \%$. Em vista das citações anteriores, é aconselhāvel a adição de ácido bórico 0,8 M, nos métodos que usam fluoreto de amônio no extrator, aumentando as vantagens dos mésmos.

o mētodo de CATANI et alii, ou IAC, apresentou resultados muito bons, justificando o seu uso como análise de rotina no IAC. Apresentou solução extratora límpida, adequada relação solo:extrator, e fácil metodologia.

O método de Mehlich apresentou resultados bons, solução extratora límpida, adequada relação solo:extrator, e facilidade no trabalho de laboratório.

O método de Olsen et alii, foi o que apresentou maiores problemas. Apresentou solução extratora amarelada, por dispersão de argila e matéria orgânica, sendo isto um grande inconveniente na determinação fotocolorimétrica do P pelo método do azul de molibdênio, já que não se pode interpo lar adequadamente os dados experimentais dos solos, na curva padrão, pois o intervalo de absorção de luz nos dois casos, é diferente. Por outro lado, os carvões testados, necessários para a floculação da maioria da argila e matéria orgânica, apresentam fósforo em maior ou menor quantidade, pelo qual de- 
ve-se lavar previamente com solução de bicarbonato, com 0 qual o fósforo é eliminado, mas não se pode ter certeza de que posteriormente esse carvão não irá absorver parte do $P$ contido na solução extratora. Um outro problema deste método, é a efervescência que acontece quando são misturadas a so lução extratora e o reativo sulfomolíbdico, o qual pode apresentar problemas. Por último, de não ser neutralizada, e aci dificada a solução para o uso fotocolorimétrico de uma forma precisa, corre-se o risco de que a cor desenvolvida com 0 reativo sulfomolíbdica, não seja estável com o tempo, o qual também é fonte de erros.

De todo o considerado anteriormente, pode-se separar os extratores usados no presente trabalho, em ordem decrescente segundo a sua importância, an seguinte forma:

$$
\begin{aligned}
& \text { a.- IAC e Mehlich; } \\
& \text { b.- Bray P-2; } \\
& \text { c.- Bray P-1; } \\
& \text { d.- Olsen et alii. }
\end{aligned}
$$

\subsubsection{Fósforo Orgãnico}

Na Tabela 4 tem-se os valores obtidos para 0 fósforo orgânico de cada solo, com os dois métodos usados. 
.43.

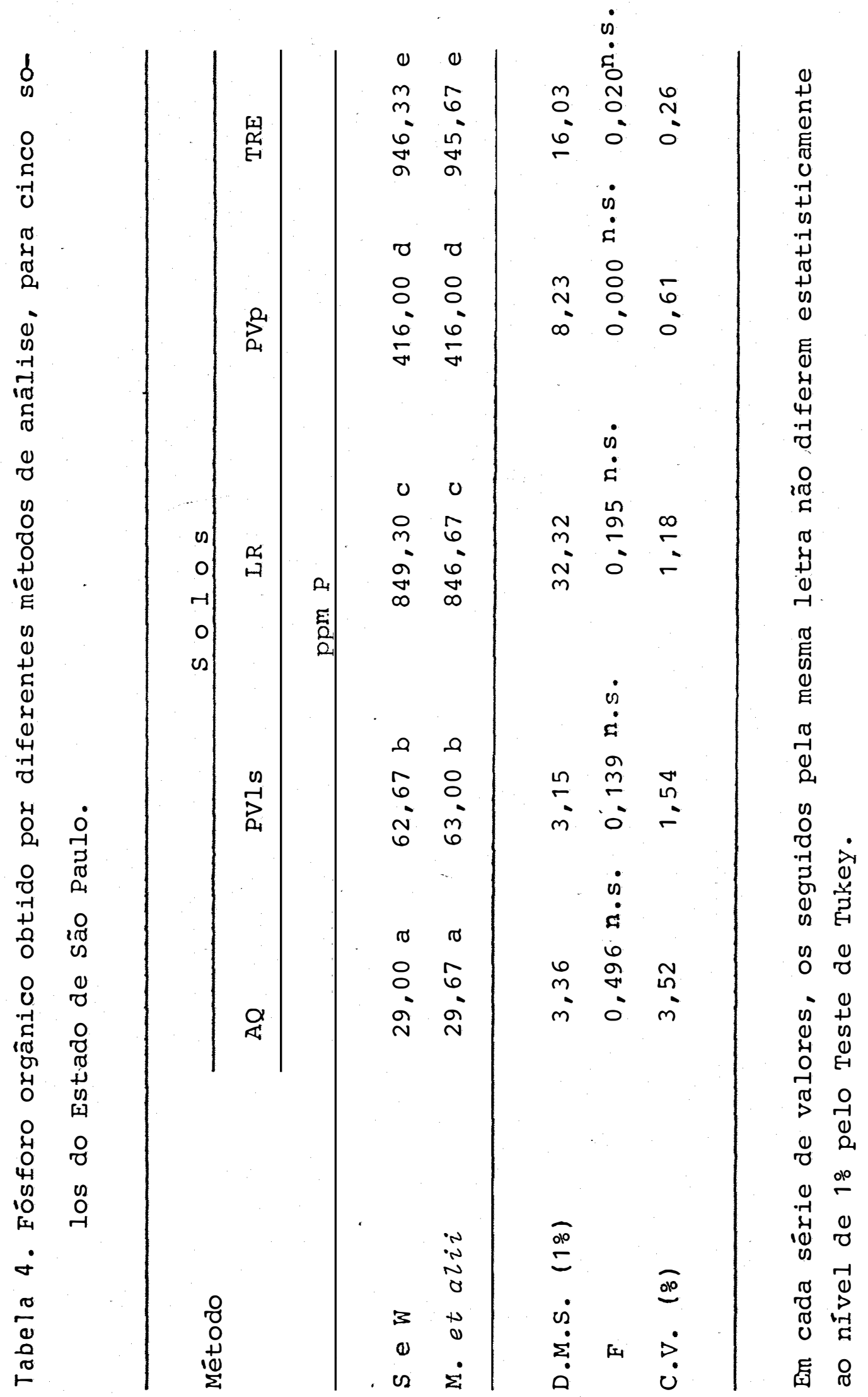


Observa-se uma tendência geral em quanto conteúdo de C.Org o dos solos (Tabela 1), e a quantidade de Fós foro Orgânico determinada nos mesmos.

Observa-se no Gráfico 2, que a maior quantidade de $\mathrm{P}$ orgânico se apresenta na TRE, $\mathrm{e}$ a menor na Areia Quartzosa.

Os dois métodos usados não apresentaram diferença estatisticamente significativa para nenhum dos solos.

As quantidades de Fósforo Orgânico em cada so10, acompanham de certa forma as médias de fósforo solúvel nos mesmos (Gráfico 1), entre os cincos solos e para os cinco métodos, sendo que a única diferença notável se apresenta no LR, O qual tem maior conteúdo de $\mathrm{P}$ orgânico que O PVp, mas apresenta menor quantidade de $\mathrm{P}$ solúvel (Tabela 3 ) do que este.

\subsubsection{Fósforo Total}

Os resultados obtidos para cada solo, pelos três métodos de análise usados, estão apresentados na Tabela 5 .

Pode-se observar que, enquanto que os métodos de Sommers e Nelson e de Jackson apresentaram aproximadamente os mesmos valores (Gráfico 3), tendo diferença estatisticamen te significativa: somente na TRE, o método de Catani e Bata- 
.45 .

PPmP

Sounders e Willioms

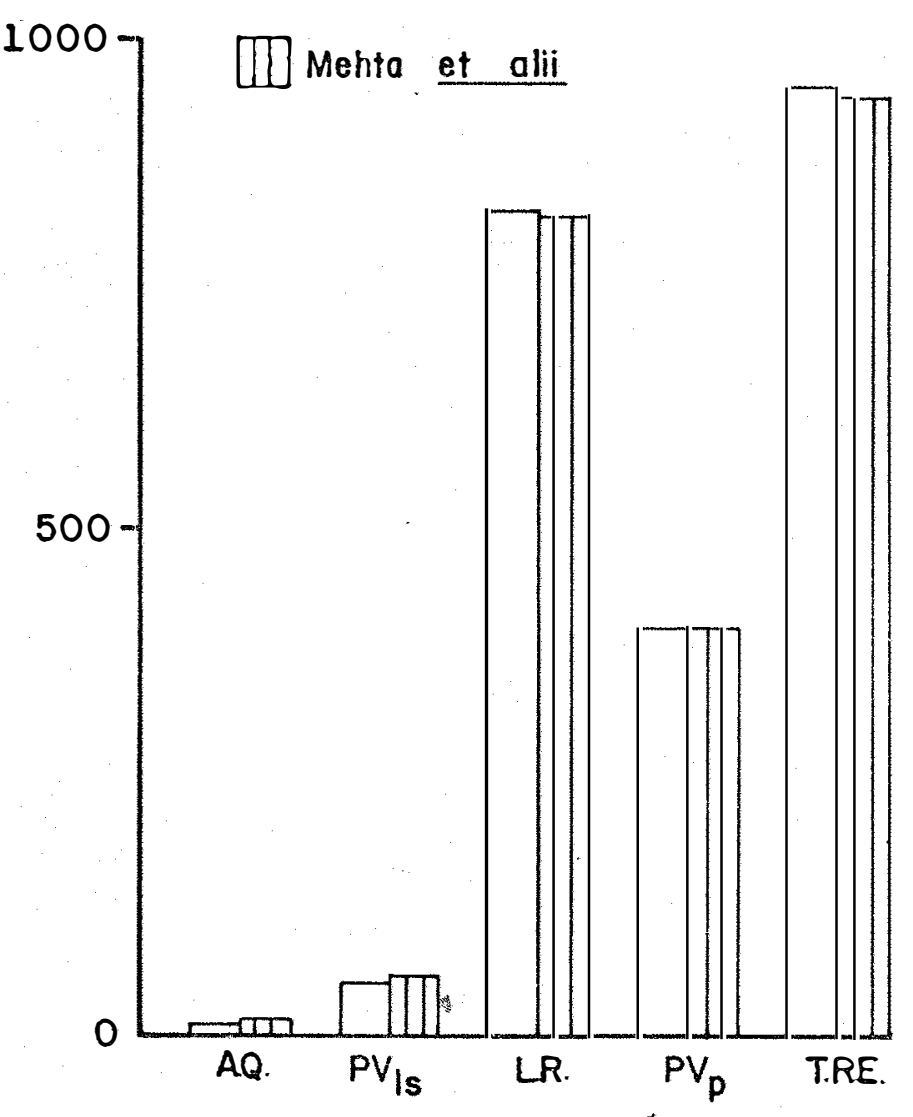

GRÁFICO 2 : Fósforo Orgânico nos dife rentes solos, por diferentes métodos de análise. 
glia apresentou resultados muito inferiores aos anteriores, com uma alta diferença significativa $(P<0,01)$ com os primei ros.

Por outro lado, pode-se notar nos três métodos (Gráfico 3), que a sequência de valores para o $P$ total dos dí ferentes solos, é a mesma, ou seja: TRE > LR > PVp > PVIs > AQ. Esta sequência é similar a do fósforo orgânico nos diferentes solos.

Os resultados obtidos pelos dois primeiros métodos., apresentam concordância com os valores obtidos para o P orgânico, no entanto, o método de Catani apresenta resulta dos muito inferiores aos do $P$ orgânico, o qual não é possível, já que o $\mathrm{P}$ total do solo é a soma dos valores de $\mathrm{P}$ orgânico e P inorgânico.

Na Tabela 6, tem-se as porcentagens de Fósforo Solúvel, segundo os métodos empregados para analisar as quantidad̄es de $\mathrm{P}$ solúvel e de $\mathrm{P}$ total. De uma forma geral, obser va-se que a tendência das porcentagens é a seguinte:

PVls $\geqq A Q>P V P>T R E>L R$

Isto nos indica que um solo, por exemplo $O \mathrm{AQ}$ e o PVls apesar de ter muito pouco fósforo disponível em ter mos absolutos, apresenta uma alta porcentagem do mesmo. 


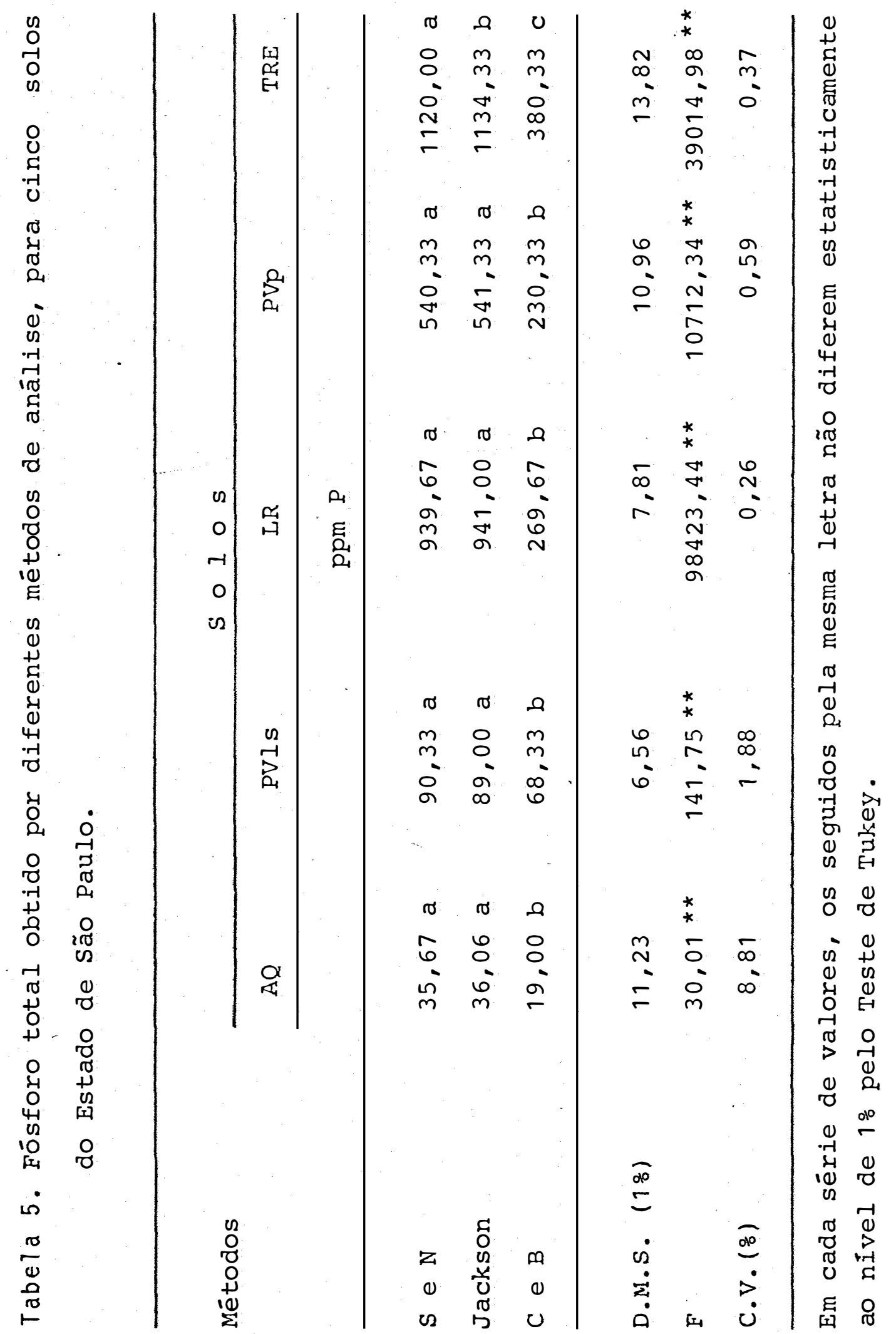




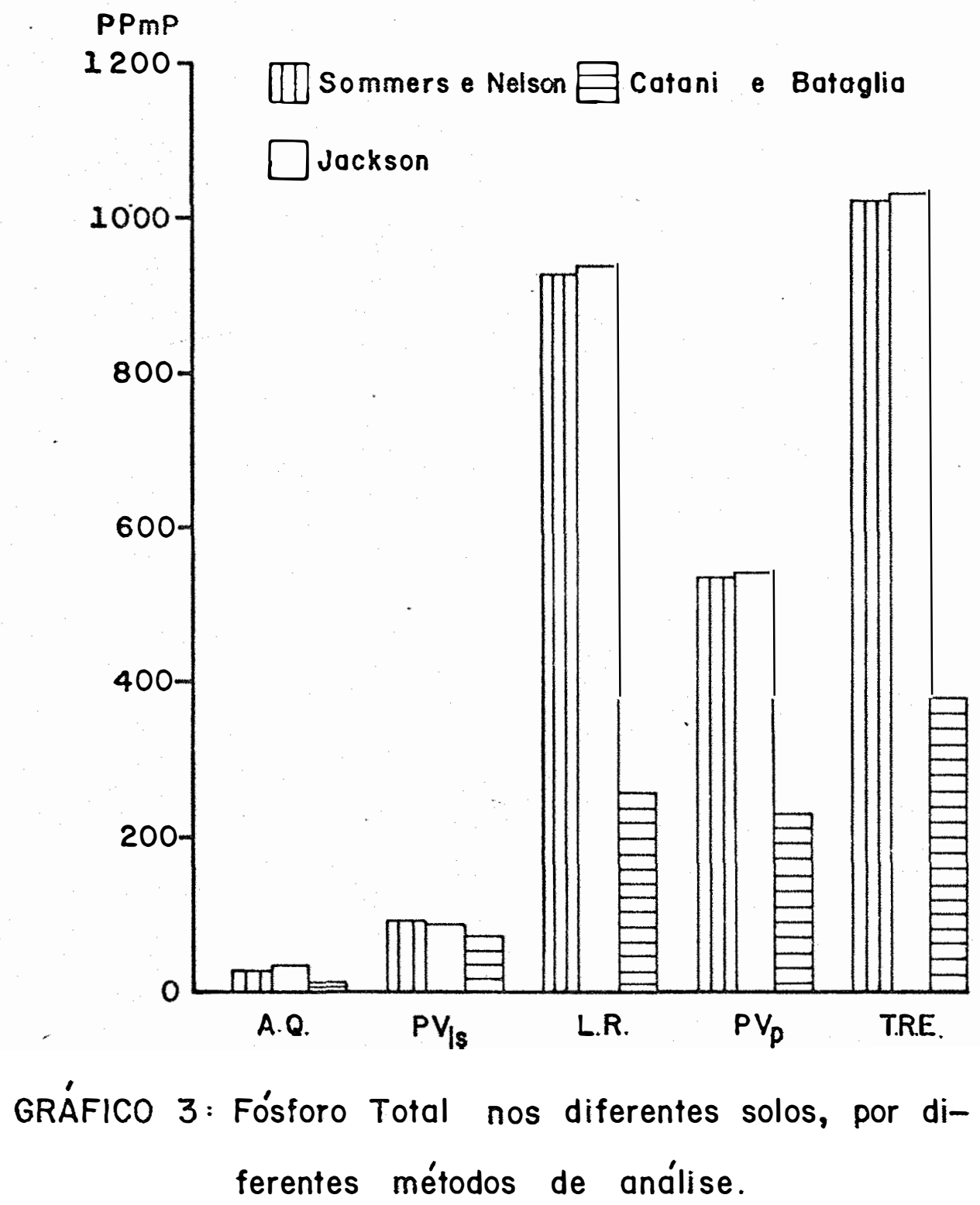




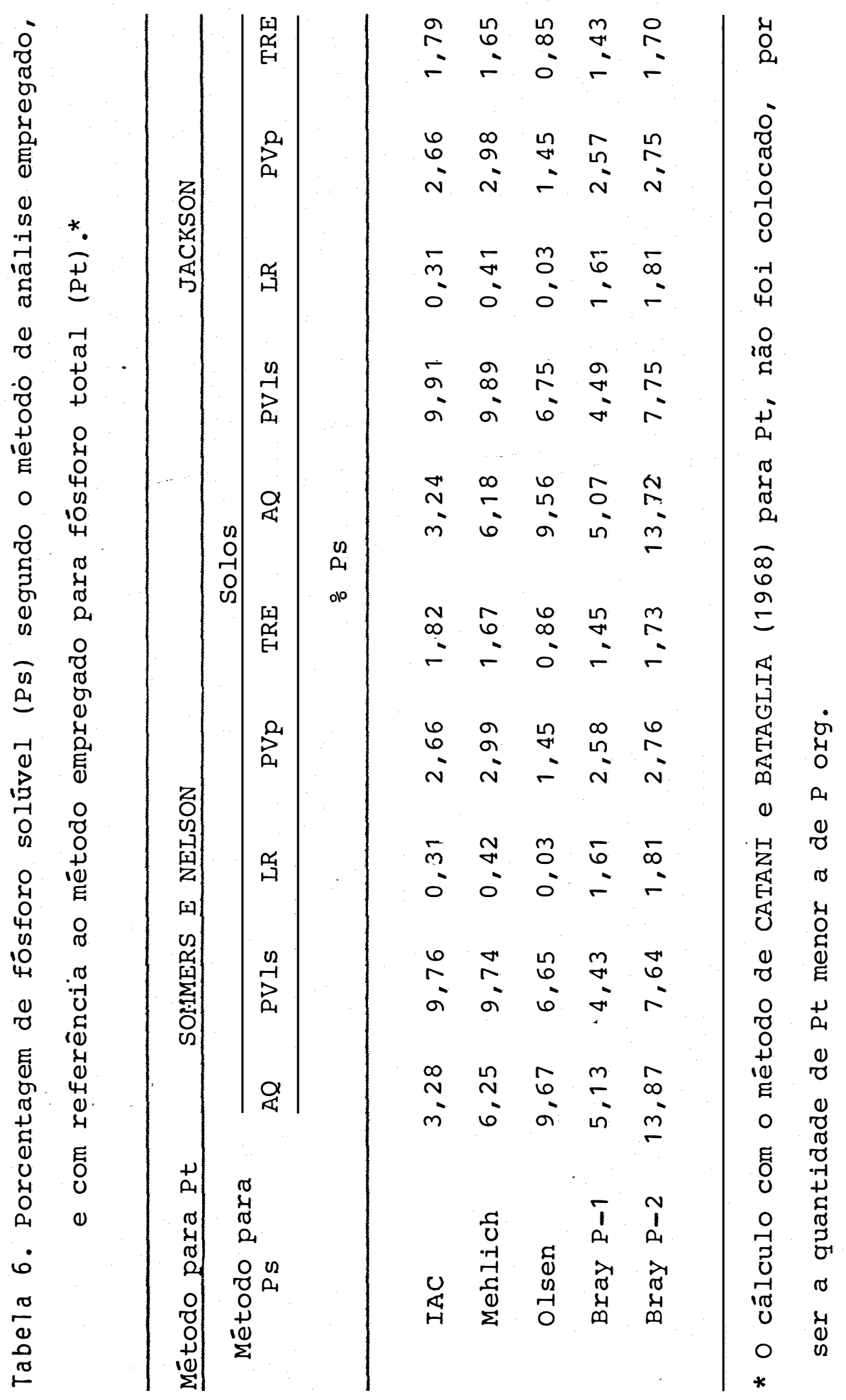


Por outra parte, solo com bastante quantidade absoluta de fósforo solúvel, como a TRE (Tabela 3), apresenta uma porcentagem muito baixa em relação aos anteriores.

Na Tabela 7, apresentam-se os dados referentes às porcentagens de Fósforo Orgânico, com referência aos métodos usados para determinar o Fósforo Total e o Fósforo Orgâni co.

A tendência geral è a seguinte, para os diferentes solos estudados:

$$
\mathrm{LR}>\mathrm{TRE}>\mathrm{AQ}>\mathrm{PV}_{\mathrm{P}}>\mathrm{PVIS}
$$

Ve-se que o LR, o qual apresenta a maior quantidade de C. Org. $\because$ (Tabela 1), apresenta também a maior porcentagem de $\mathrm{P}$ orgânico. No entanto, a $\mathrm{AQ}$, a qual têm a menor quantidade de C. Org. $\%$, não é a que apresenta menor porcenta gem de $\mathrm{P}$ orgânico.

4.3. Ensaios em Casa de Vegetação

4.3.1. Feijoeiro

Nas Figuras 1 e 2, tem-se o aspecto das plantas de feijoeiro, aos 18 e 40 dias após o plantio, respectiva mente, para os diferentes solos e os diferentes níveis de fós foro adicionado ao solo. 


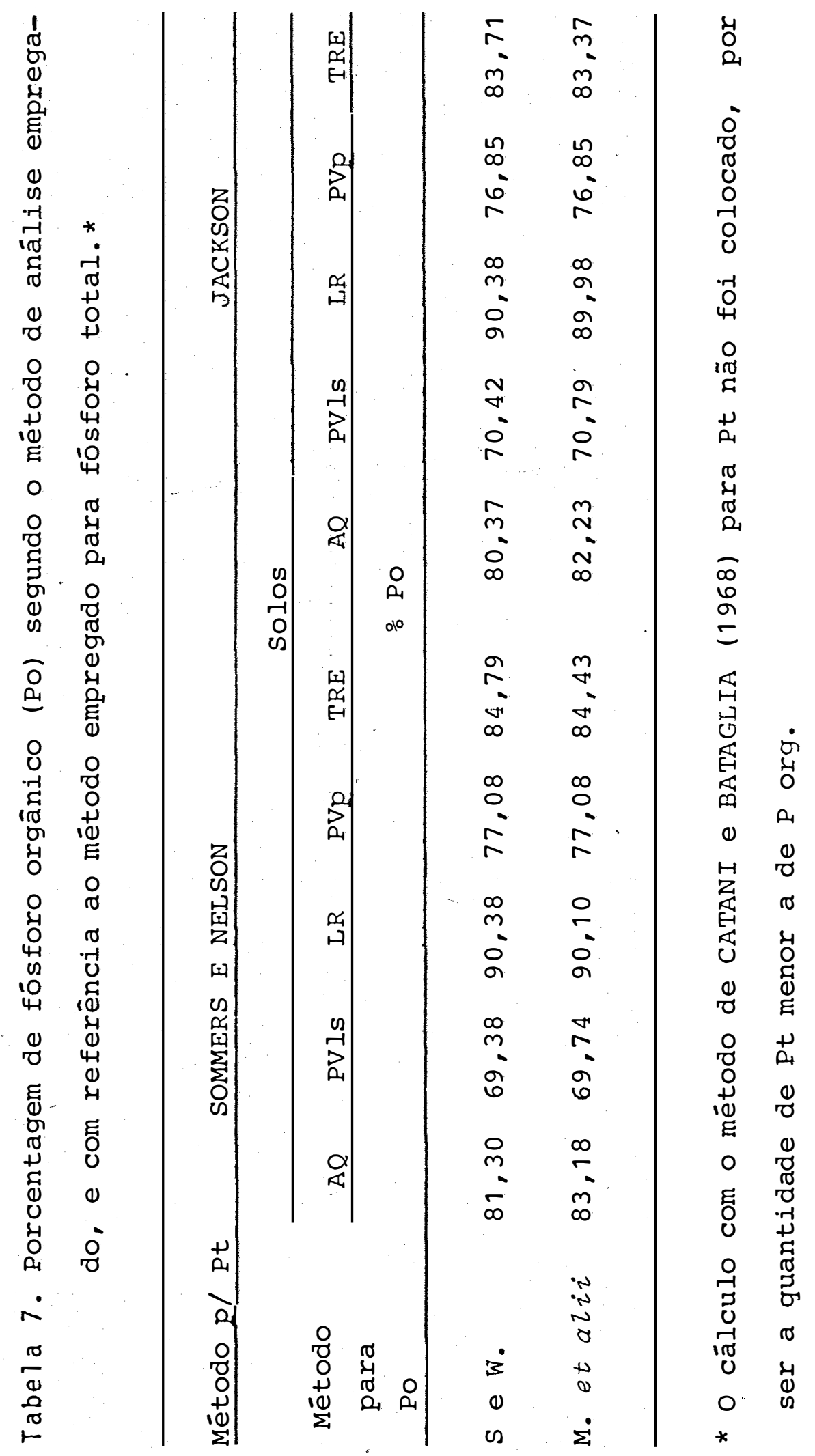



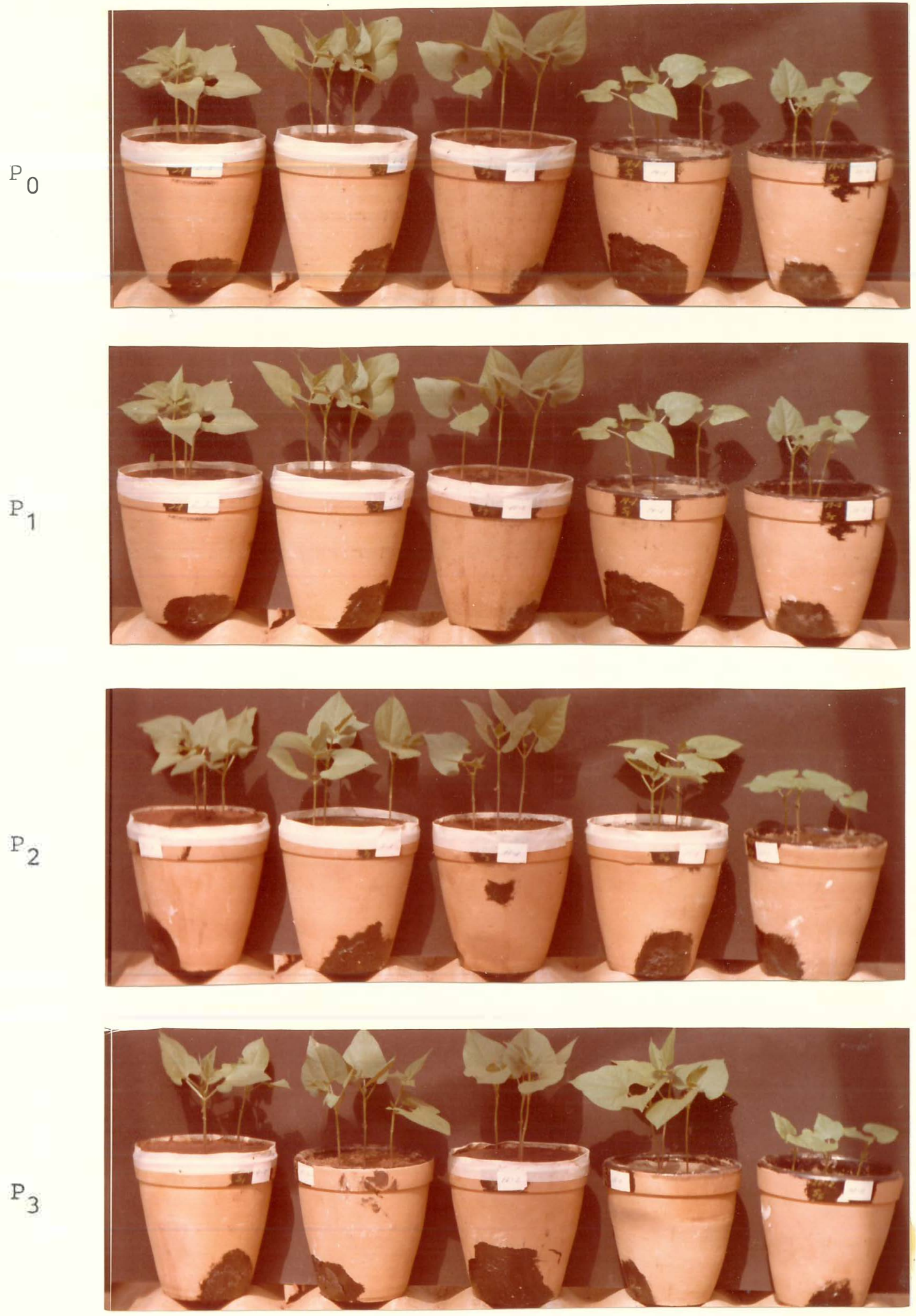

Figura 1. Feijoeiro em casa de vegetação aos 18 dias após o plantio, para diferentes níveis de fósforo adiciona do ao solo, e para diferentes solos. 

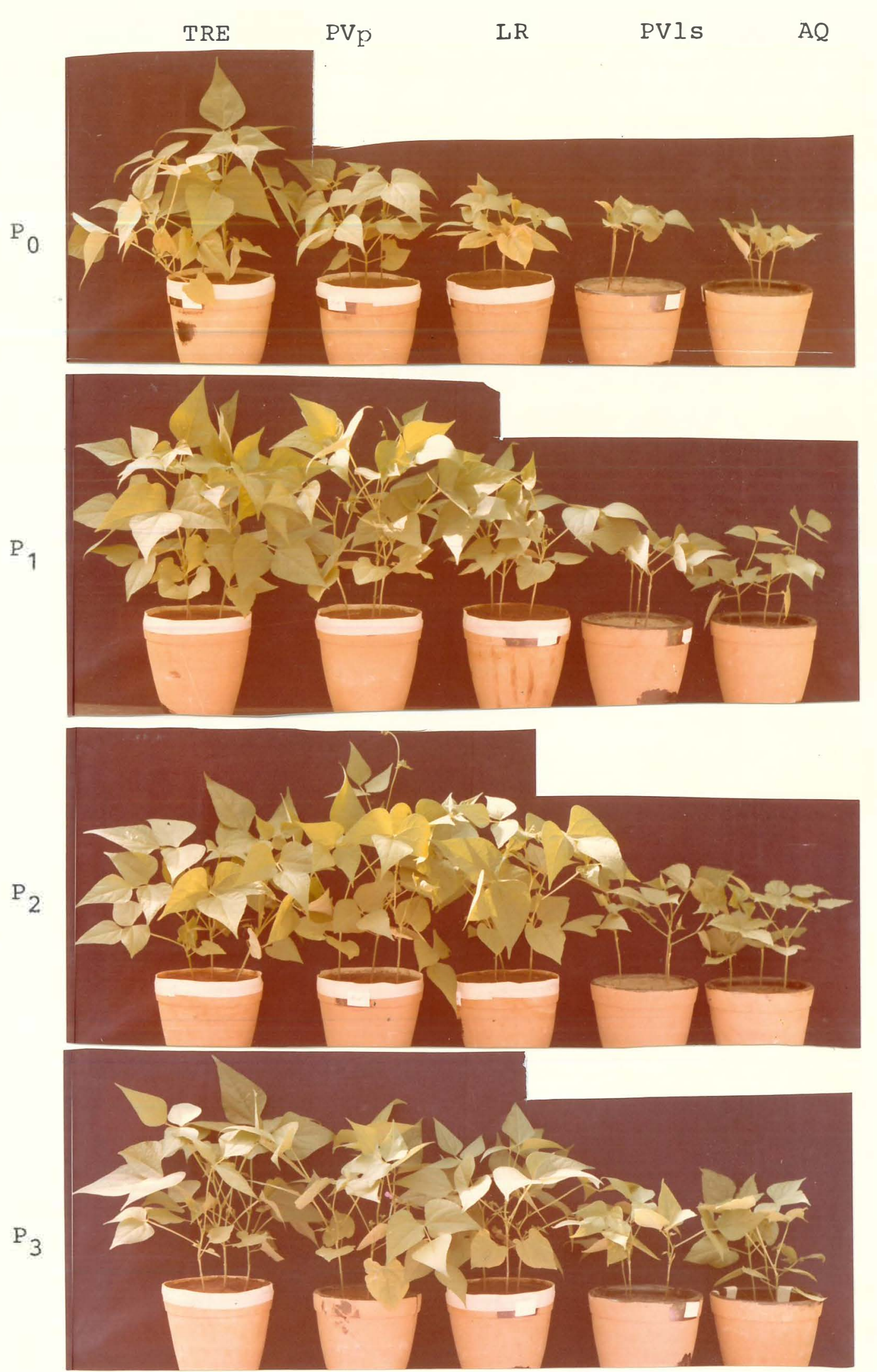

Figura 2. Feijoeiro em casa de vegetação aos 40 dias após o plantio, para diferentes níveis de fósforo adiciona do ao solo, e para diferentes solos. 
Na Tabela 8, tem-se os resultados de Matéria Vegetal Seca, e de Fósforo Total na MVS, obtido após 60 dias de plantio os quais podem ser visualizados nos Gráficos 4 e 5 .

Os dados desta Tabela, observa-se que a quantí dade de Matéria Vegetal Seca, e de Fósforo Total,aumentou com a quantidade de fósforo adicionado ao solo, para todos os solos.

Quanto aos níveis de fósforo adicionado ao so10, e a quantidade de matéria vegetal seca produzida em cada um dos diferentes solos, tem-se as seguintes sequência:

$$
\begin{aligned}
& \mathrm{P}_{0} \text { e } \mathrm{P}_{1}: \mathrm{TRE} \geqq \mathrm{PVP}>\mathrm{LR}>\mathrm{PVls}=\mathrm{AQ} \\
& \mathrm{P}_{2} \text { e } \mathrm{P}_{3}: \mathrm{PVP}=\mathrm{TRE}>\mathrm{LR}>\mathrm{PVIS}=\mathrm{AQ}
\end{aligned}
$$

Encontrou-se diferença estatística significati va, ao nível de 5\% de probabilidade, entre as quantidades de MVS produzidas aos níveis $\mathrm{P}_{0}$ e $\mathrm{P}_{1}$ de fósforo adicionado, em todos os solos. No PVls e LR, apresentou-se diferença estatística significativa entre todos os níveis de $\mathrm{P}$ adicionado. Na $A Q$ e PVp, não se apresentou diferença estatística significativa na quantidade de MVS produzida nos niveis $\mathrm{P}_{2}$ e $\mathrm{P}_{3}$ de 


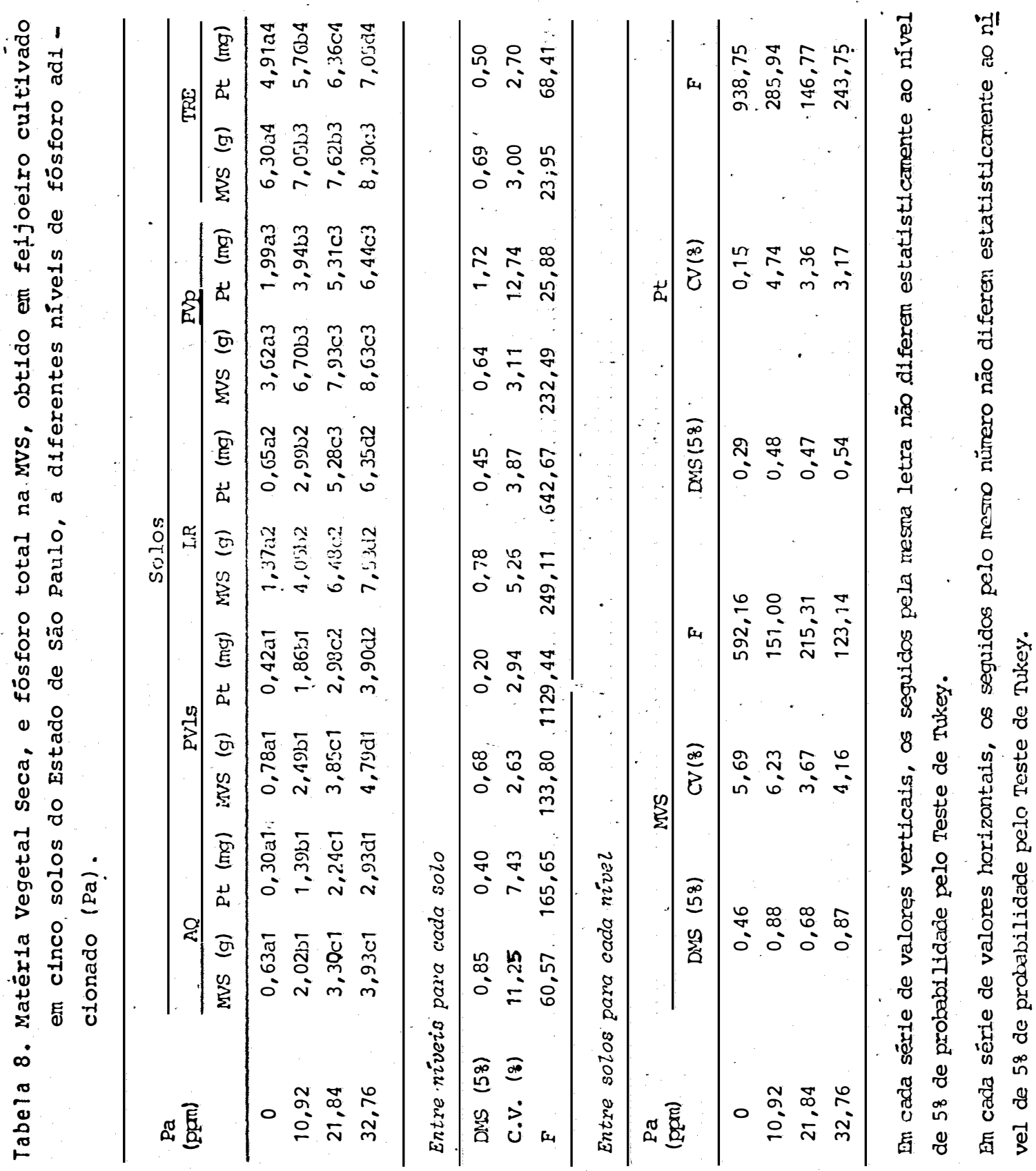


.56 .

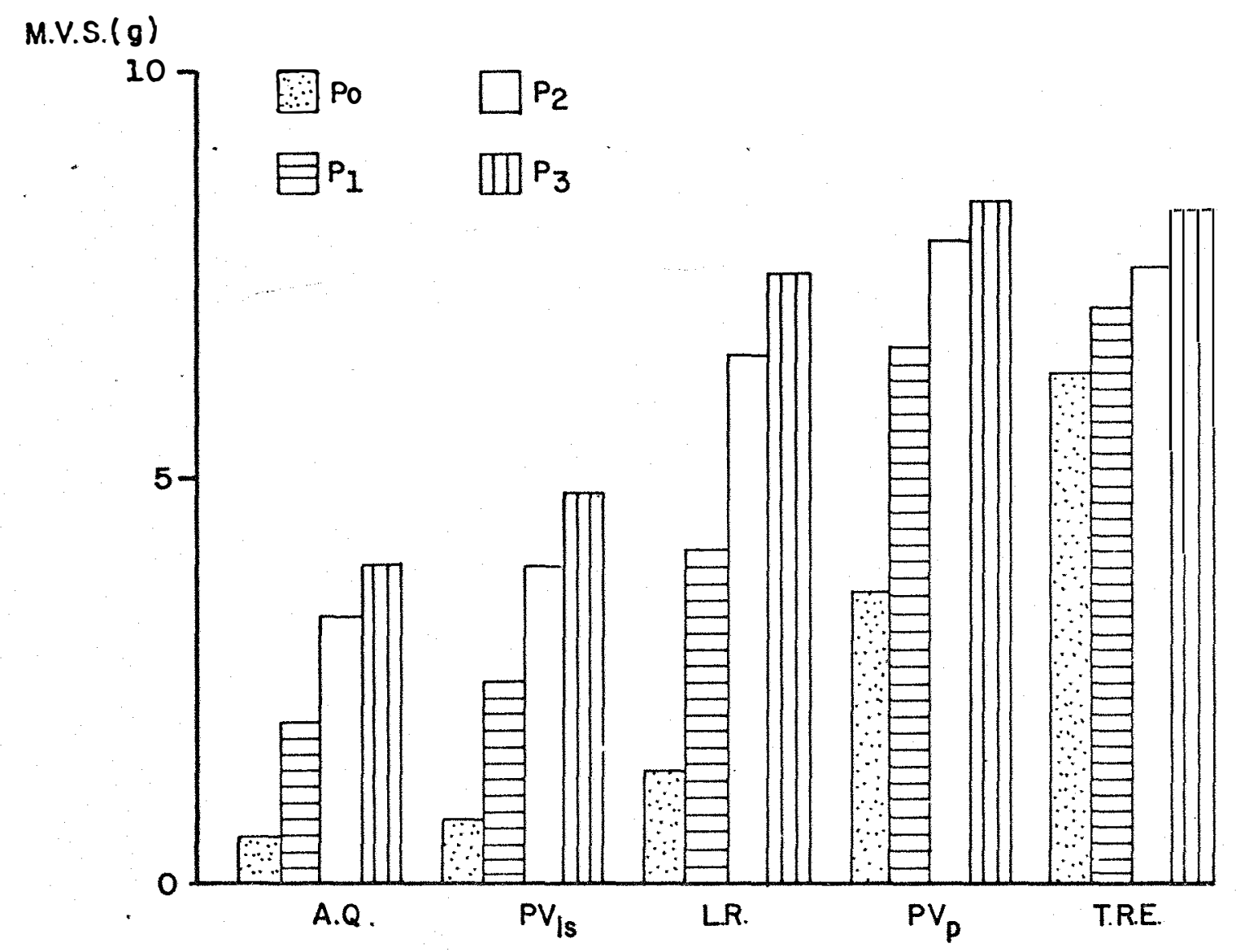

GRÁFICO 4: Matéria Vegetal Seca produzida pelo Feijoeiro para diferentes níveis de Fósforo Adicionado, e nos diferentes solos. 
fósforo adicionado. Na TRE, não se apresentou diferença estą tistica significativa entre as quantidades de MVS produzida aos níveis $\mathrm{P}_{1}$ e $\mathrm{P}_{2}$ de fósforo adicionado ao solo.

Com referência as quantidades de MVS produzi das nos diferentes solos, visualizado no Gráfico 4, verificou -se que, para todos os níveis de $\mathrm{P}$ adicionado, não se encontrou diferença estatistica significativa entre as quantidades de MVS produzida na $A Q$ e no PVls. Encontrou-se diferença estatistica significativa, para a MVS produzida ao nível $\mathrm{P}_{0}$, en tre os solos PVp e TRE; ao nível $\mathrm{P}_{3}$, não se encontrou diferença estatistica significativa, nas quantidades de MVS pro duzida nesses dois solos; aos níveis $\mathrm{P}_{1}$ e $\mathrm{P}_{2}$, encontrou-se $\mathrm{di}$. ferença estatística significativa entre as quantidades de MVS produzidas nos solos LR e PVp, mas não entre o PVp e O TRE.

Para o Fósforo Total ná MVS de Feijoeiro, tem-se a seguinte sequência para os diferentes níveis de $\mathrm{P}$ adicionado ao solo:

$$
\begin{aligned}
& \mathrm{P}_{0} \text { e } \mathrm{P}_{1}: \mathrm{TRE}>\mathrm{PVP}>\mathrm{LR}>\mathrm{PVIS}=\mathrm{AQ} \\
& \mathrm{P}_{2} \text { e } \mathrm{P}_{3}: \mathrm{TRE}>\mathrm{PVP}=\mathrm{LR}>\mathrm{PVIS}>\mathrm{AQ}
\end{aligned}
$$

Observou-se diferença significativa nas quantí dades de $\mathrm{P}$ Total na MVS, entre todos os solos, com exceção dos solos $A Q$ e PVls para os níveis de $P_{0}$ e $P_{1}$ de fósforo adicionado, e entre o $\mathrm{P}$ total na MVS no LR e no PVp nos niveis de $\mathrm{P}$ aplicado $\mathrm{P}_{2}$ e $\mathrm{P}_{3}$. 
.58 .

$a^{N} a^{m}$

$\stackrel{0}{a} a^{-1}$

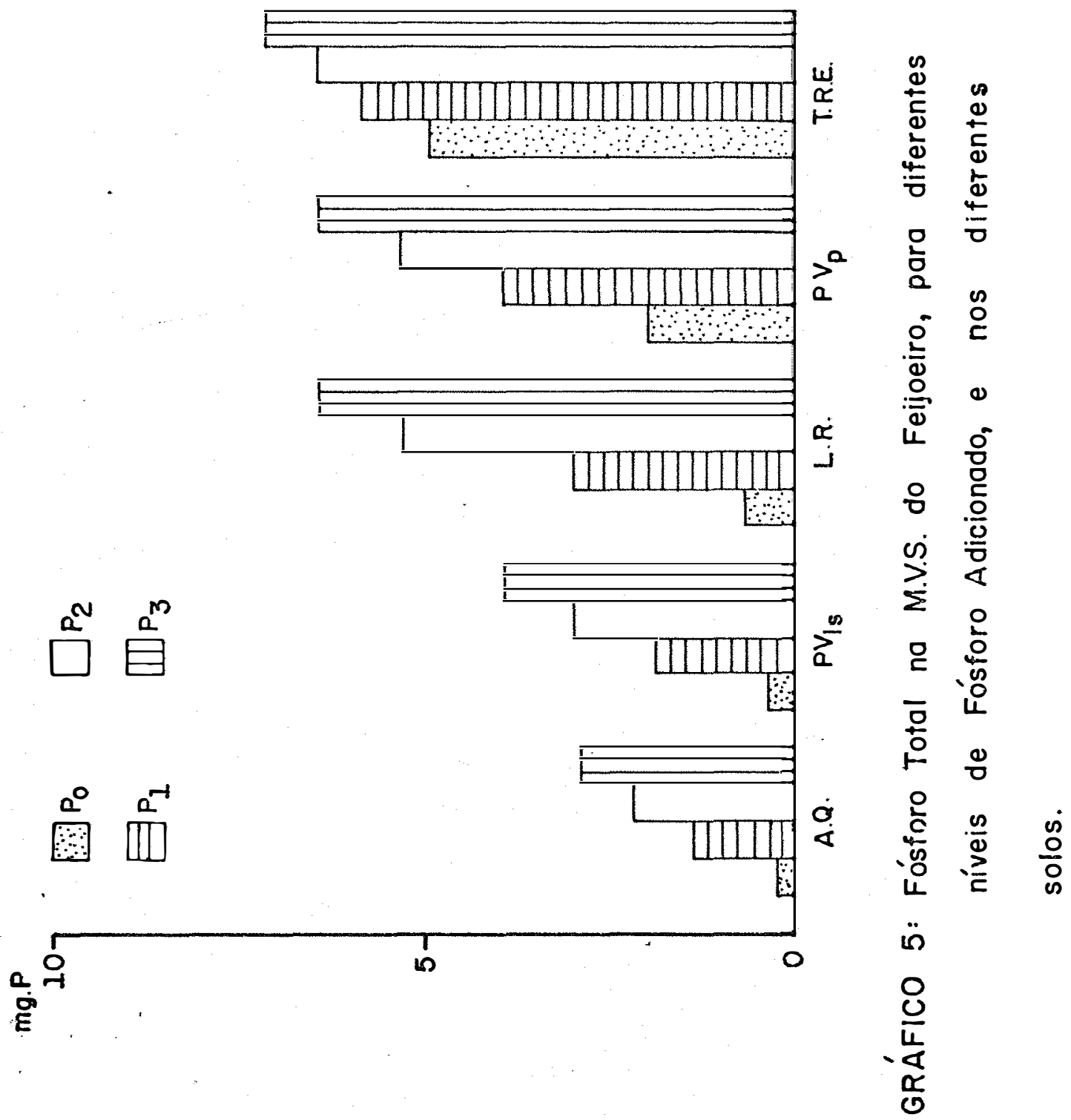


Para cada solo em particular, observou-se dife rença significativa na quantidade de $\mathrm{P}$ total produzido nos dí ferentes níveis de $\mathrm{P}$ adicionado, exceto entre os níveis $\mathrm{P}_{2} \mathrm{e}$ $\mathrm{P}_{3}$ do PVP.

Nas Tabelas 9, 10, e 11, se apresentam os resul tados dos cálculos de Produção Relativa, com referência a máxima produção obtida em cada solo, e com referência máxima produção de MVS de todos os solos. Também estão dados os resultados dos cálculos da porcentagem de utilização eficiente do Fósforo adicionado ao solo, e os incrementos na Produção de MVS.

Os cálculos foram feitos da forma seguinte:

$$
\operatorname{PRS}(\%)=\frac{\operatorname{MVS}(\mathrm{Pn})}{\operatorname{MVS}\left(\mathrm{P}_{3}\right)} \times 100
$$

sendo,

$\mathrm{n}=0,1$ ou 2

$\operatorname{MVS}\left(\mathrm{P}_{3}\right)=$ Matéria Vegetal Seca ao nível $\mathrm{P}_{3}$ pa ra cada solo.

$$
\operatorname{PRT}(\%)=\frac{\operatorname{MVS}(\operatorname{Pn})}{\operatorname{MVS}(\text { máxima })}
$$

sendo,

$\mathrm{n}=0,1,2$ ou 3

MVS (máxima) = Máxima produção de MVS para todos os solos 


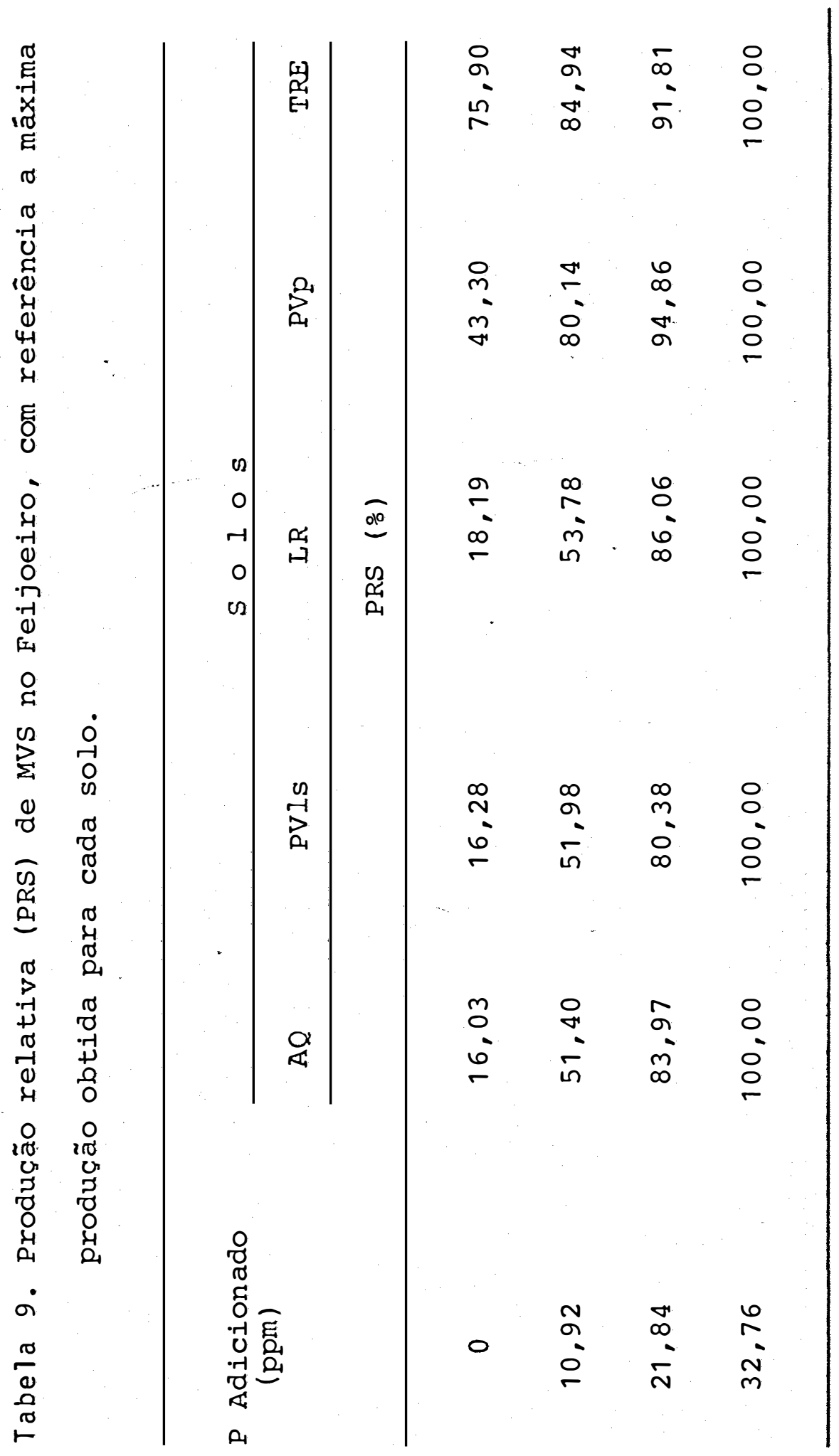




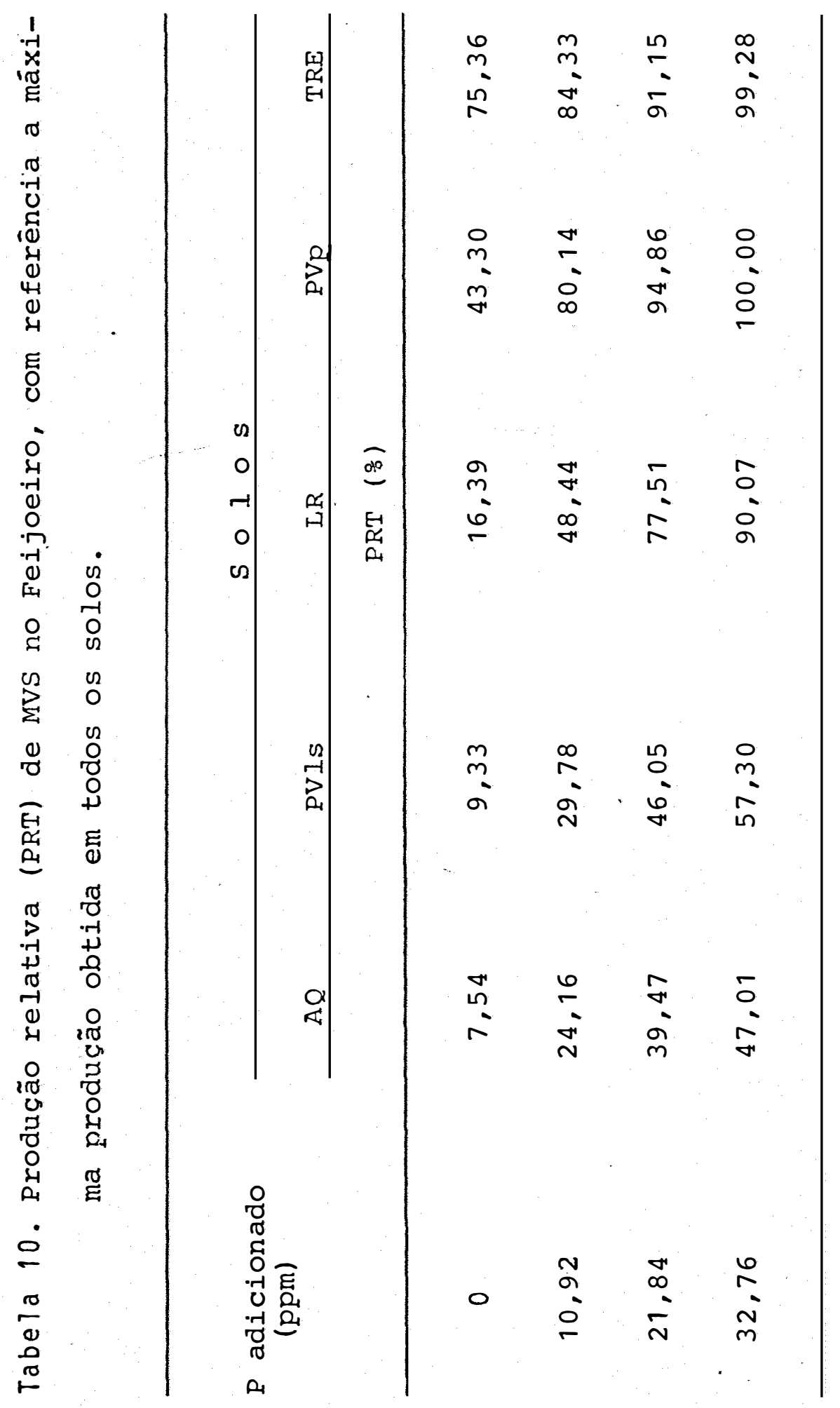


.62 .

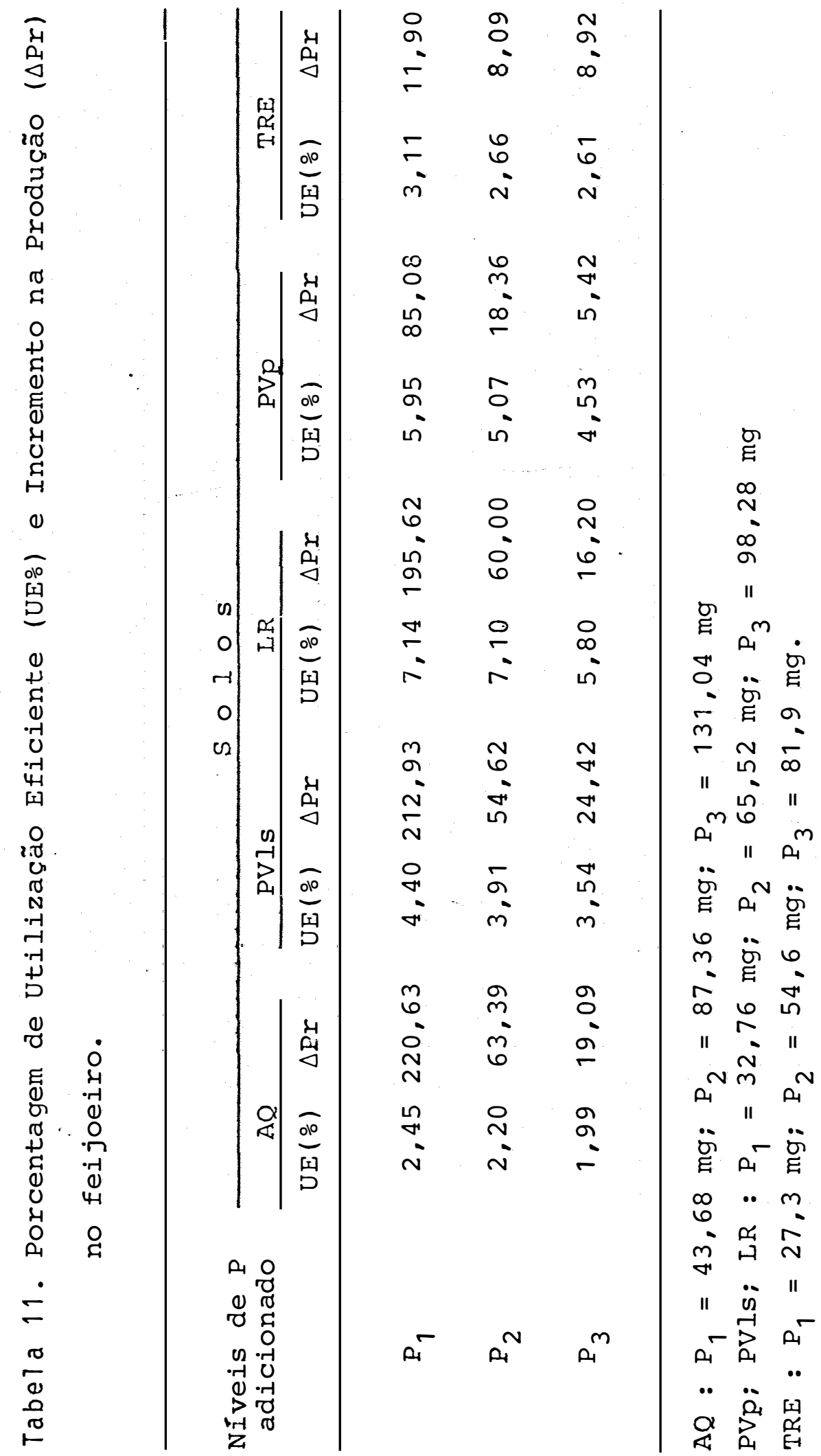




$$
\text { U.E. }\left(\frac{\circ}{\circ}\right)=\frac{P t_{(P n)}-P t_{(P o)}}{P n(\text { Adic. })} \times 100
$$

sendo que:

$$
\begin{aligned}
\mathrm{Pt}_{(\mathrm{Pn})}= & \text { Fósforo Total na MVS aos níveis de } \\
& \mathrm{Pn}=\mathrm{P}_{1}, \mathrm{P}_{2}, \mathrm{P}_{3} ; \\
\mathrm{Pt}_{(\mathrm{Po})}= & \text { Fósforo Total na MVS ao nível } \mathrm{P}_{0} \text { de } \mathrm{P} \\
& \text { adicionado; } \\
\mathrm{Pn}_{(\text {Adic.) }=} & \text { Fósforo Adicionado ao solo, em } \mathrm{mg}, \\
& \text { aos níveis de } \mathrm{Pn}=\mathrm{P}_{1}, \mathrm{P}_{2}, \mathrm{P}_{3} .
\end{aligned}
$$

Na Tabela 9, observa-se que para os solos $A Q$, PVls e LR, tem-se aproximadamente a mesma produção relativa para os diferentes níveis de $\mathrm{P}$ adicionado ao solo. No entanto, a TRE apresenta uma alta produção relativa ao nível $\mathrm{P}_{0}$ ' mas é menor ao nível $\mathrm{P}_{2}$, com referência ao $\mathrm{PVp}$.

Na Tabela 10, pode-se observar que adicionando $P$ ao solo, até os níveis $P_{3}$, na $A Q$ e no PVls, não foi alcança da a produção obtida ao nível de $\mathrm{P}_{0}$ da TRE, a qual nos indica ria que para alcançar a produção mínima da TRE, é necessário adicionar uma quantidade muito alta de $\mathrm{P}$ ao solo, no caso da $A Q$ e no PVls, um nivel $P_{2}$ para $O L R$, e um nivel $P_{1}$ para $O P V p$.

$$
\text { Pode-se dizer também que a TRE pode dar uma }
$$
produção bastante alta de MVS, com referência aos solos AQ, PVls e LR, sem aplicar nenhuma quantidade de adubo fosfatado. 
mais fértil com referência ao Fósforo, e a $A Q$ é o menos fértil.

Na Tabela 11, observa-se que a Utilização Eficiente (UE) do adubo pela planta, foi muito baixa, chegando no máximo a 7,1\% Também observa-se que, na $A Q$, no entanto, apresentaubaixo teor de P solúvel (Tabela 3), e apresentou pou ca argila ou Matéria Orgânica, que poderíam fixar o P no so10, a Utilização Eficiente é muito baixa, deduzindo-se que não é só o p adicionado que vai aumentar a Utilização Eficien te, mas que deve-se levar em conta todo o conjunto de fatores que regulam o sistema Solo-Planta.

No caso da TRE, o solo com maior quantidade de P solúvel (Tabela 3), apresentou-se o mesmo fenômeno que na $A Q$, ou seja, que a quantidade de $P$ aproveitado pelo feijoeiro foi muito pouca.

Observa-se que os incrementos na produção, se dão em maior quantidade nos solos com menor conteúdo de P solúvel (Tabela 3), sendo que os incrementos na produção relatí va, à medida que se incrementa a quantidade de $\mathrm{P}$ adicionado ao solo, diminuem com 0 aumento na quantidade de $\mathrm{P}$ solúvel no so 10 . 


\subsubsection{Mitho}

Nas Figuras 3, 4 e 5, tem-se o aspecto das plantas de Milho aos 20 e 35 dias após o plantio, para diferentes níveis de fósforo aplicados ao solo, e para diferentes solos.

Na Tabela 12, tem-se os resultados de Matéria Vegetal Séca e Fósforo Total na MVS, obtidos aos 60 dias após o plantio, no experimento efetuado com Milho em casa de vegetação.

Nos dados dessa Tabela, observa-se que a quantidade de Matéria Vegetal Seca, e de Fósforo Total na MVS, au mentou com a quantidade de Fósforo Aplicado ao solo, para os cinco solos.

Quanto aos níveis de Fósforo Aaicionado ao so10, e a quantidade de Matéria Vegetal Seca produzida em cada um dos diferentes solos (Gráfico 6), tem-se as seguintes se- . quências:

$$
\begin{array}{r}
\mathrm{P}_{0^{\prime}} \mathrm{P}_{1} \mathrm{e}_{2}: \mathrm{TRE}>\mathrm{PVp}>\mathrm{LR}>\mathrm{PVIS}=\mathrm{AQ} \\
\mathrm{P}_{3}: \mathrm{TRE}>\mathrm{PVP}>\mathrm{LR}=\mathrm{PVIS}=\mathrm{AQ}
\end{array}
$$

Levando em consideração o nível $\mathrm{P}_{0}$, observa-se, que a sequência anterior têm a mesma tendência no referente ao conteúdo dos solos em $\mathrm{K}^{+}, \mathrm{Ca}^{2+} \mathrm{e} \mathrm{Mg}^{2+}($ Tabela 1$)$, como aconteceu no Feijoeiro. 
.66 .
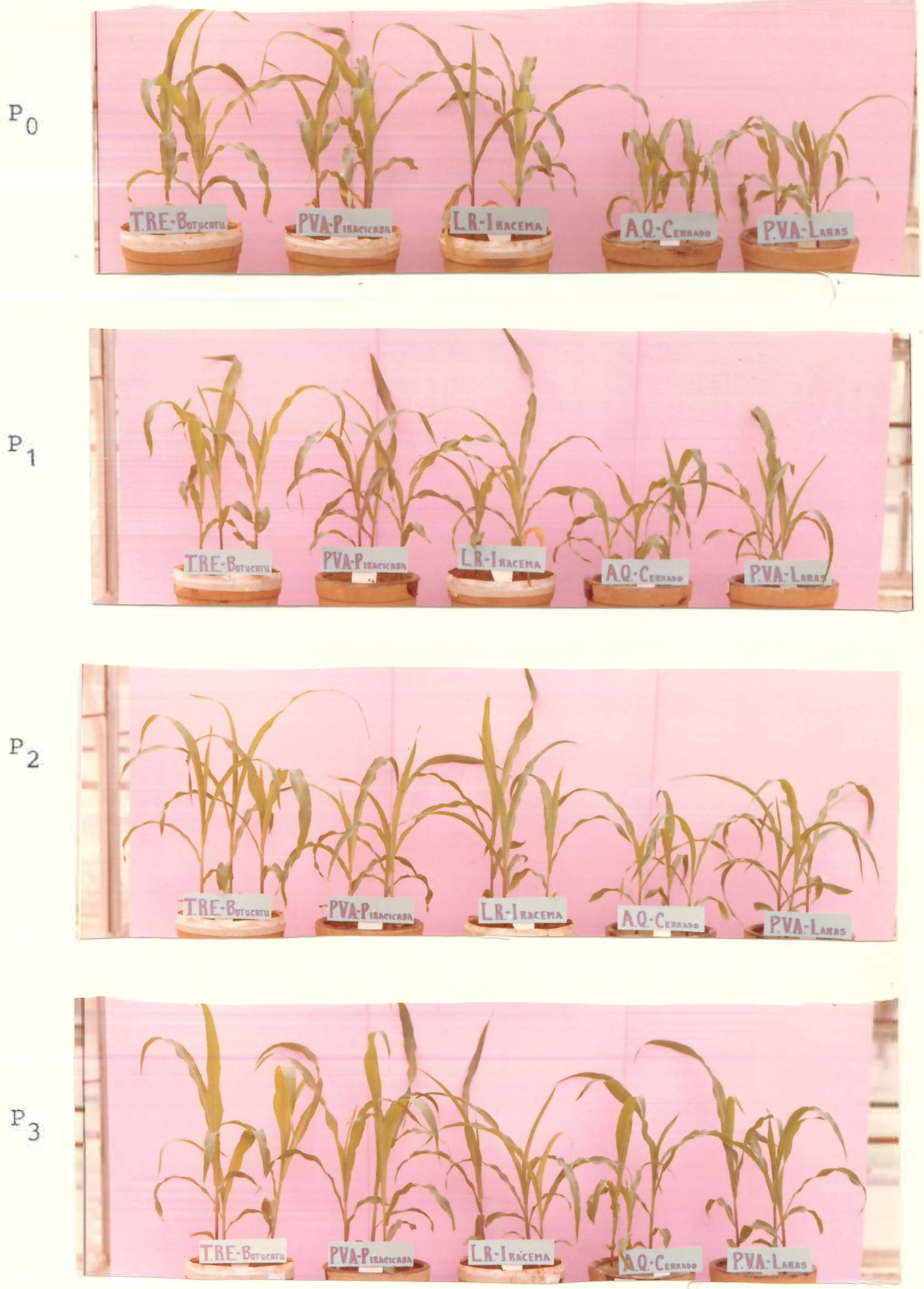

Figura 3. Milho em casa de vegetação aos 20 dias após o plantio, para diferentes níveis de Fósforo Adicionado ao Solo e para diferentes solos. 

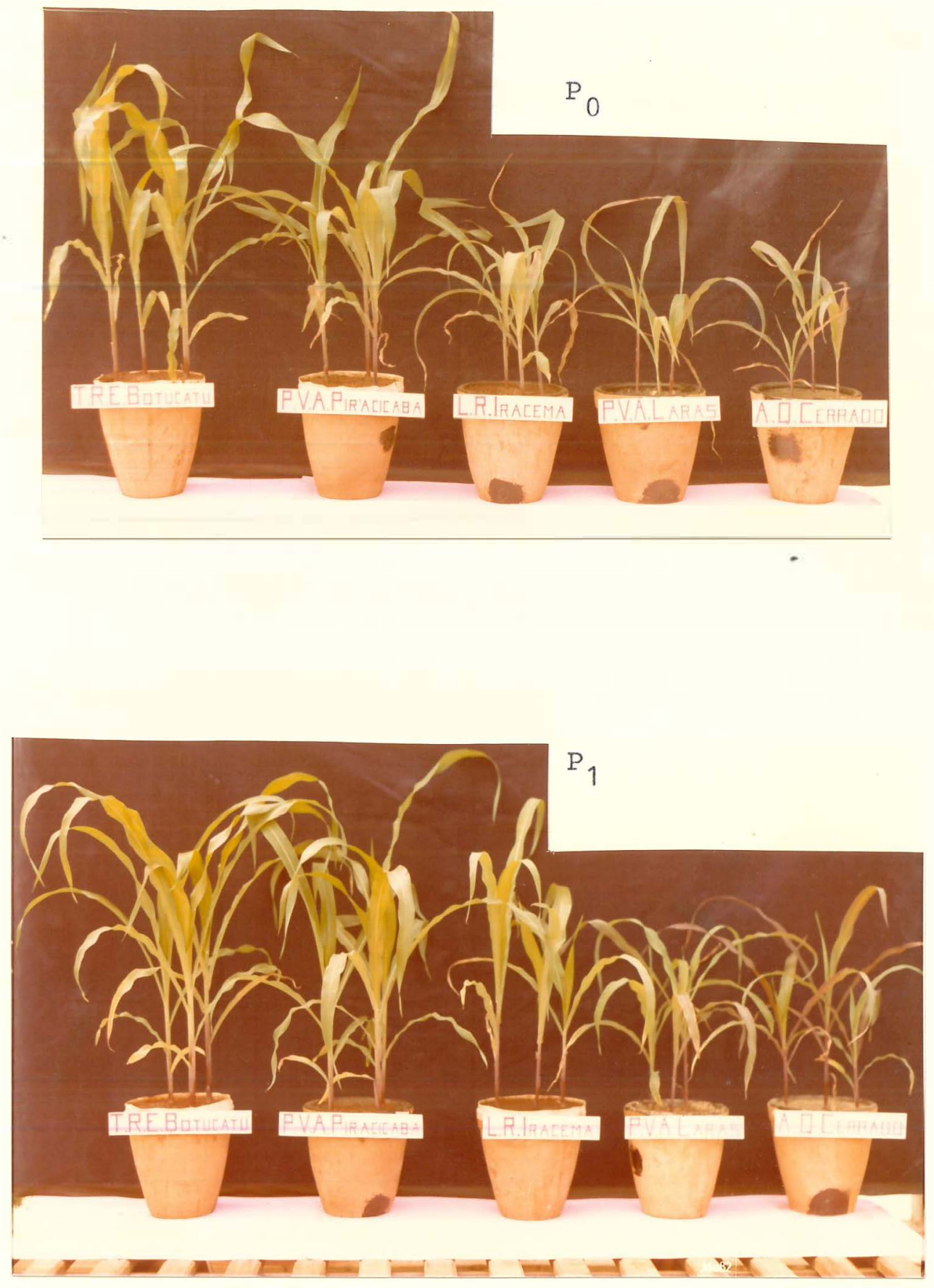

Figura 4. Milho em casa de vegetação aos 35 dias após o plantio, em diferentes solos, e para os níveis $\mathrm{P}_{0}$ e $\mathrm{P}_{1}$ de Fósforo Adicionado ao Solo. 
.68 .
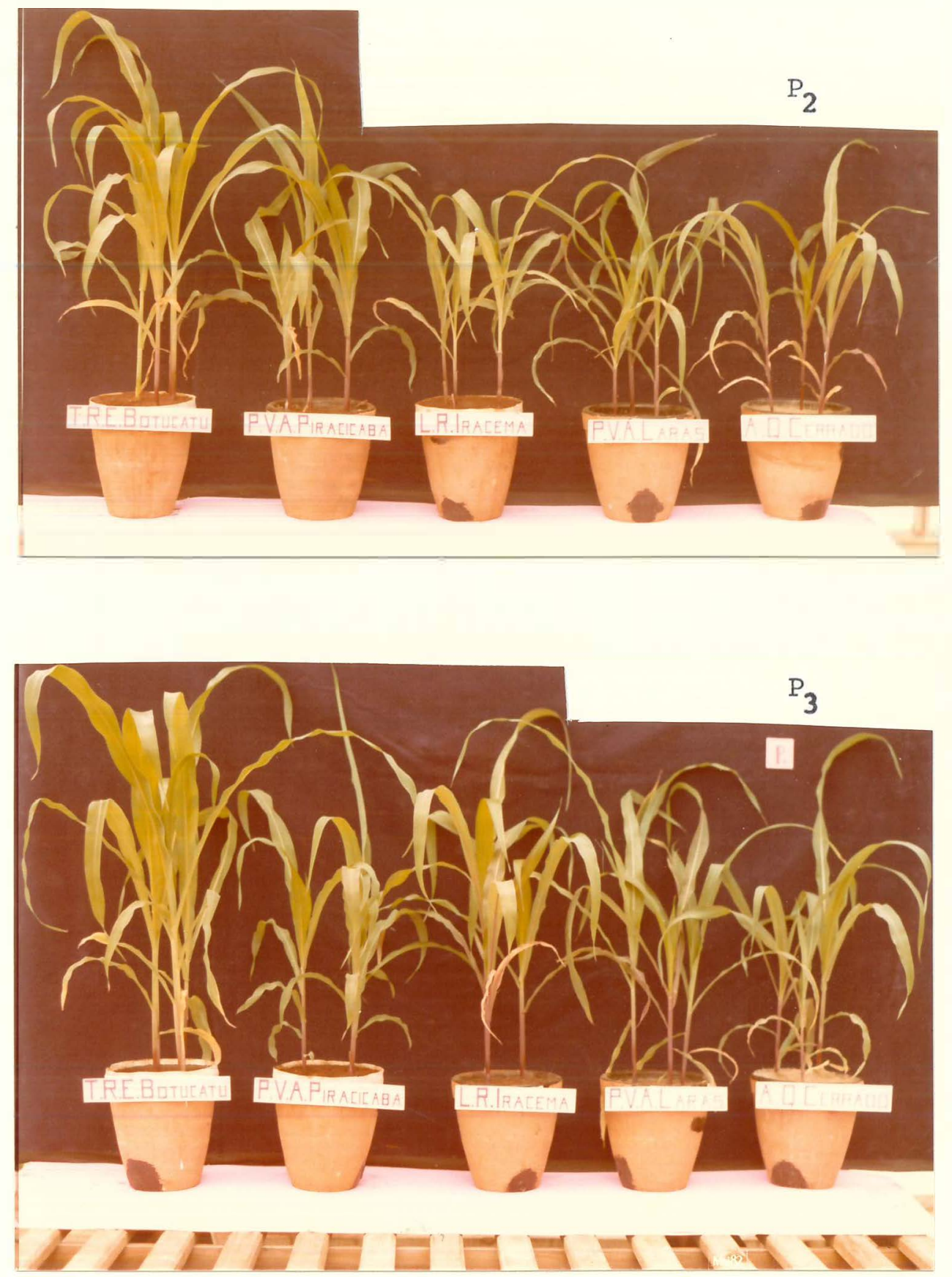

Figura 5. Milho em casa de vegetação aos 35 dias após o plantio, em diferentes solos, e para os níveis $\mathrm{P}_{2}$ e $\mathrm{P}_{3}$ de Fósforo Adicionado ao Solo. 


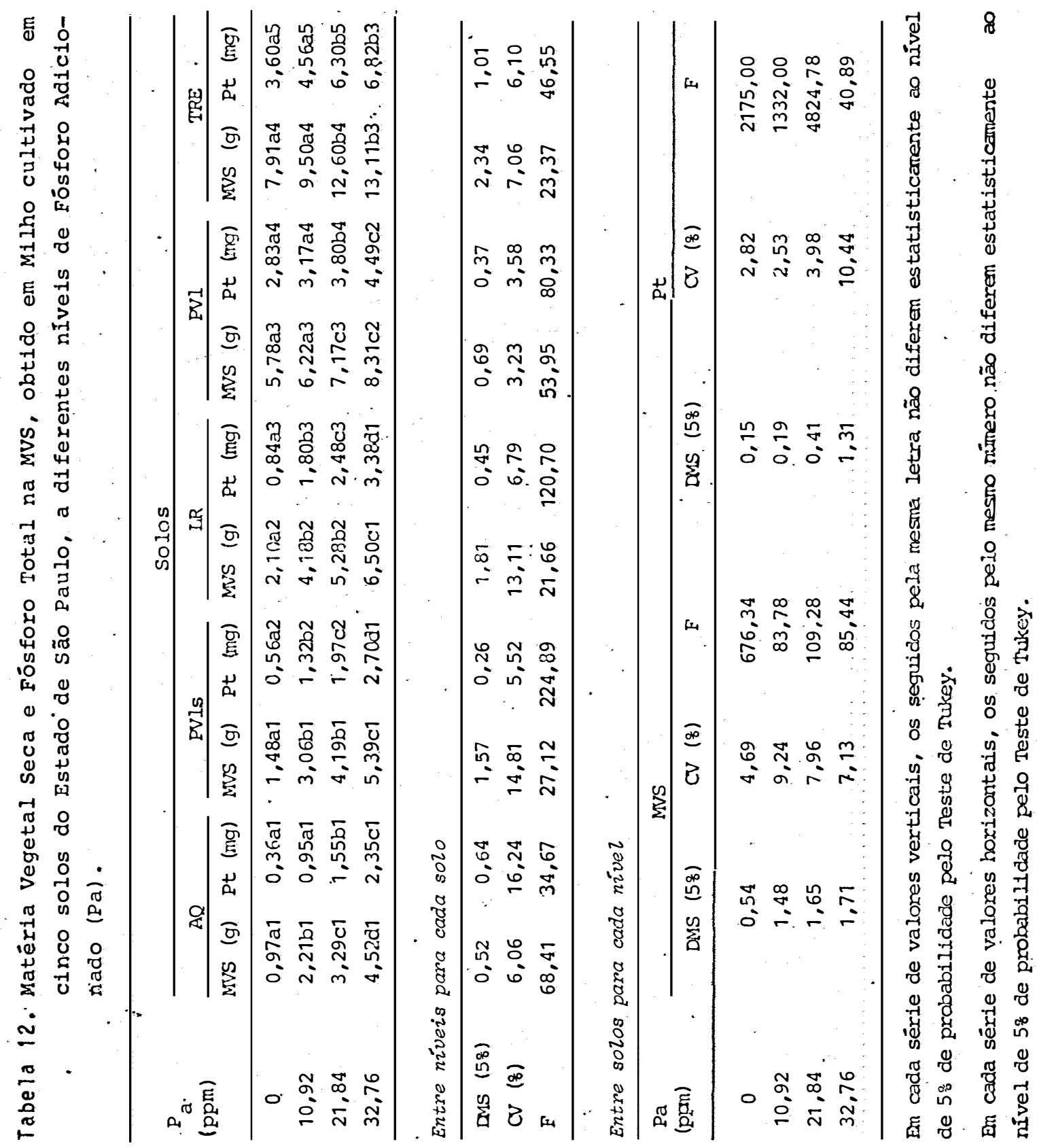




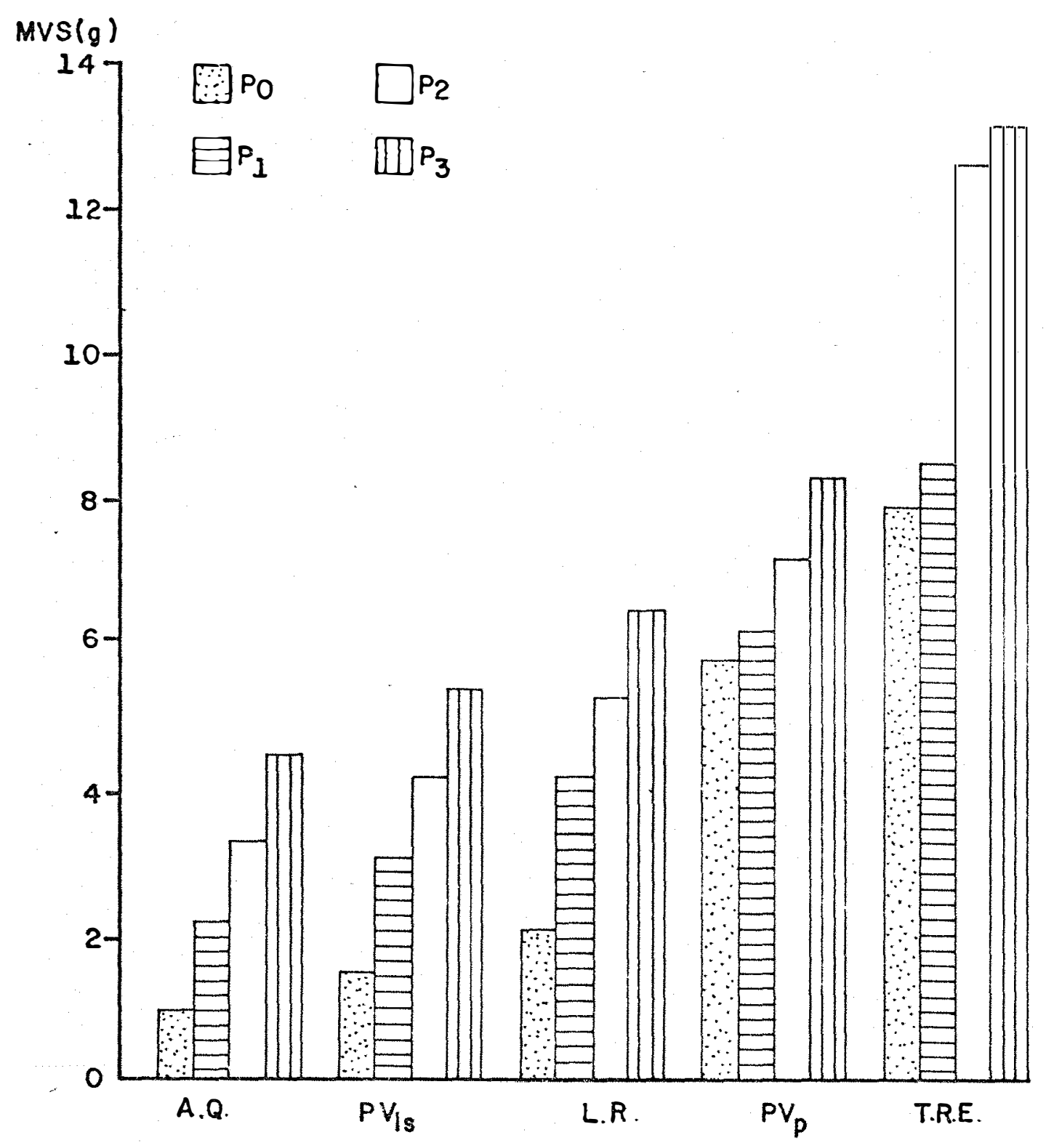

GRAFICO 6: Mấria Vegetal Seca produzida pelo Milho, para diferentes níveis de Fósforo Adicionado, e nos diferentes solos. 
Encontrou-se diferença significativa entre as quantidades de matéria vegetal seca produzida entre os solos LR, PVp e TRE, para todos os níveis de $\mathrm{P}$ adicionado.

Não se encontrou diferença significativa entre as quantidades de MVS produzida e os solos AQ e PVls, para to dos os niveis de $\mathrm{P}$ adicionado. Encontrou-se diferença significativa entre as quantidades de MVS produzida e os solos PVls e LR, para todos os níveis de $\mathrm{P}$ adicionado, menos para $\mathrm{P}_{3} \cdot$

Na $A Q$, apresentou-se diferença significativa ao nível de 5\% de probabilidade, entre a MVS produzida a todos os níveis de P adicionado ao solo. No PVls, não se apresentou diferença significativa entre a MVS produzida nos níveis $\mathrm{P}_{1} \mathrm{e}$ $\mathrm{P}_{2}$, apresentando-se entre os outros níveis. No LR apresentou-se a mesma situação que no PVls. No PVp e na TRE, não se apresentou diferença significativa entre a MVS produzida nos níveis $\mathrm{P}_{0}$ e $\mathrm{P}_{1}$ de $\mathrm{P}$ adicionado, para cada solo, no entanto,. no PVp, apresentou-se diferença entre os nĩveis $\mathrm{P}_{2}$ e $\mathrm{P}_{3}$, além disto, não se apresentou diferença significativa entre a MVS produzida nos níveis $\mathrm{P}_{2}$ e $\mathrm{P}_{3}$ na $T R E$, tendo só diferença signi ficativa entre os niveis $\mathrm{P}_{1}$ e $\mathrm{P}_{2}$.

Para o Fósforo Total na MVS de Milho visualizado no Gráfico 7, tem-se a seguinte sequência para os diferentes niveis de $\mathrm{P}$ adicionado ao solo: 


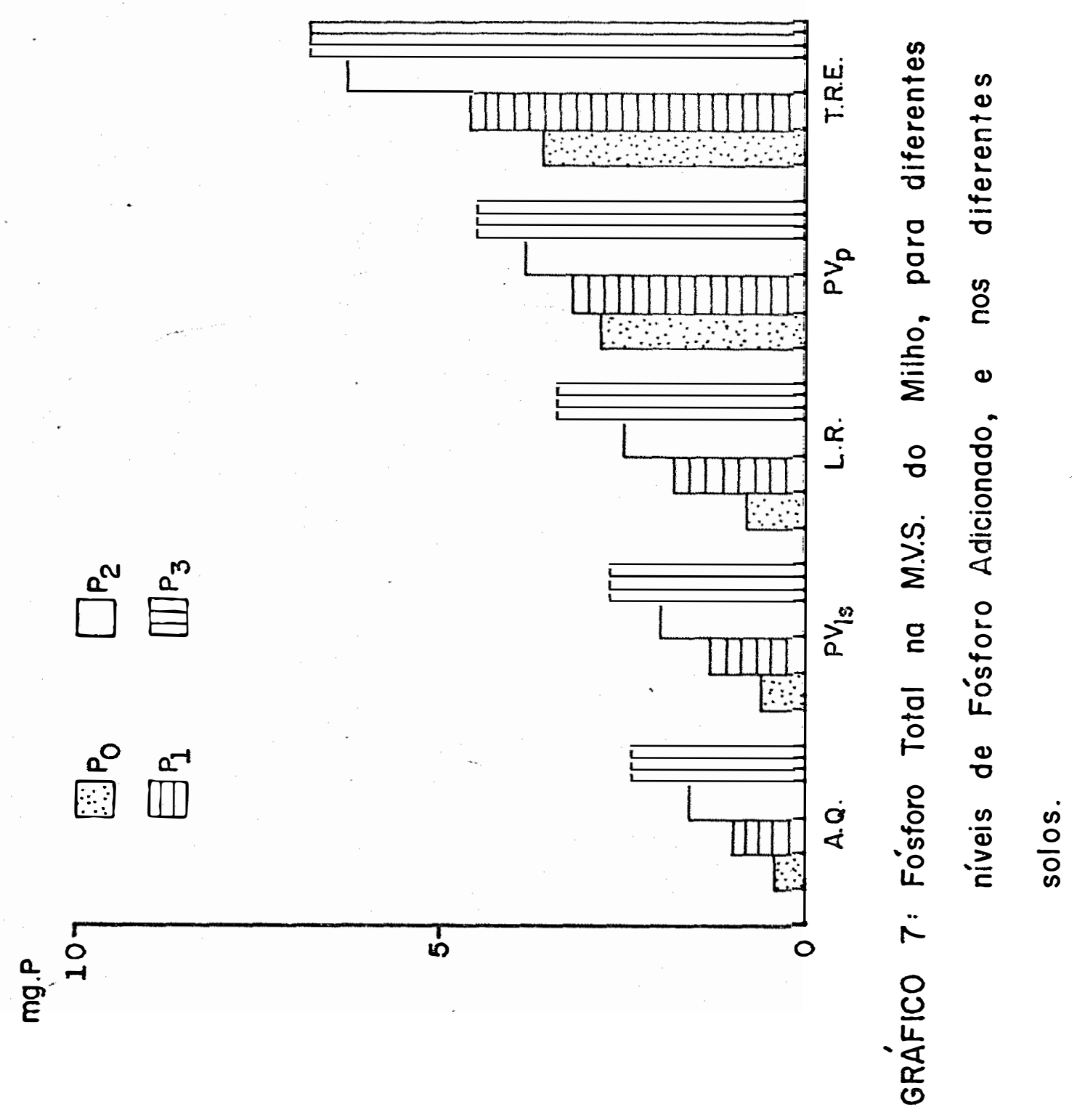




$$
\begin{aligned}
\mathrm{P}_{0^{\prime}} \mathrm{P}_{1} \mathrm{eP}_{2}: \mathrm{TRE}>\mathrm{PVP}>\mathrm{LR}>\mathrm{PVIS}>\mathrm{AQ} \\
\mathrm{P}_{3}: \mathrm{TRE}>\mathrm{PVP}>\mathrm{LR}=\mathrm{PVIS}=\mathrm{AQ}
\end{aligned}
$$

Observou-se diferença significativa entre $O \quad P$ total na MVS, entre todos os solos e a todos os niveis de $P$ adicionado, menos ao nível $\mathrm{P}_{3}$, no qual não se observou diferença significativa entre os solos $A Q$, PVls e LR.

Para cada solo em particular, observaram-se diferenças significativas entre as quantidades de $P$ total na MVS, e todos os niveis de P adicionado, no PVls e no LR. Na AQ, PVp e TRE, não se observou diferença significativa entre as quantidades de $\mathrm{P}$ total na MVS, para os niveis $\mathrm{P}_{0}$ e $\mathrm{P}_{1}$, tam bém não houve entre os niveis $\mathrm{P}_{2} \mathrm{e}_{3}$ da TRE. Foram signifi cativas as diferenças entre $O P$ total nos níveis restantes de $\mathrm{P}$ adicionado para os três solos anotados.

Nas Tabelas 13, 14 e 15, se apresentam os resul tados dos cálculos de Produção Relativa, com referência a māxima produção obtida em cada solo, e com referência a máxima produção de MVS entre todos os solos. Também estão os resultados dos cálculos de percentagem e os incrementos na produção de MVS para cada solo. Os cálculos foram feitos de manei ra similar que para Feijoeiro.

Na Tabela 13, observa-se que os solos AQ e PVls apresentam a mesma tendência no referente a produção relativa de MVS, no entanto, não se observa o mesmo nos outros solos, 


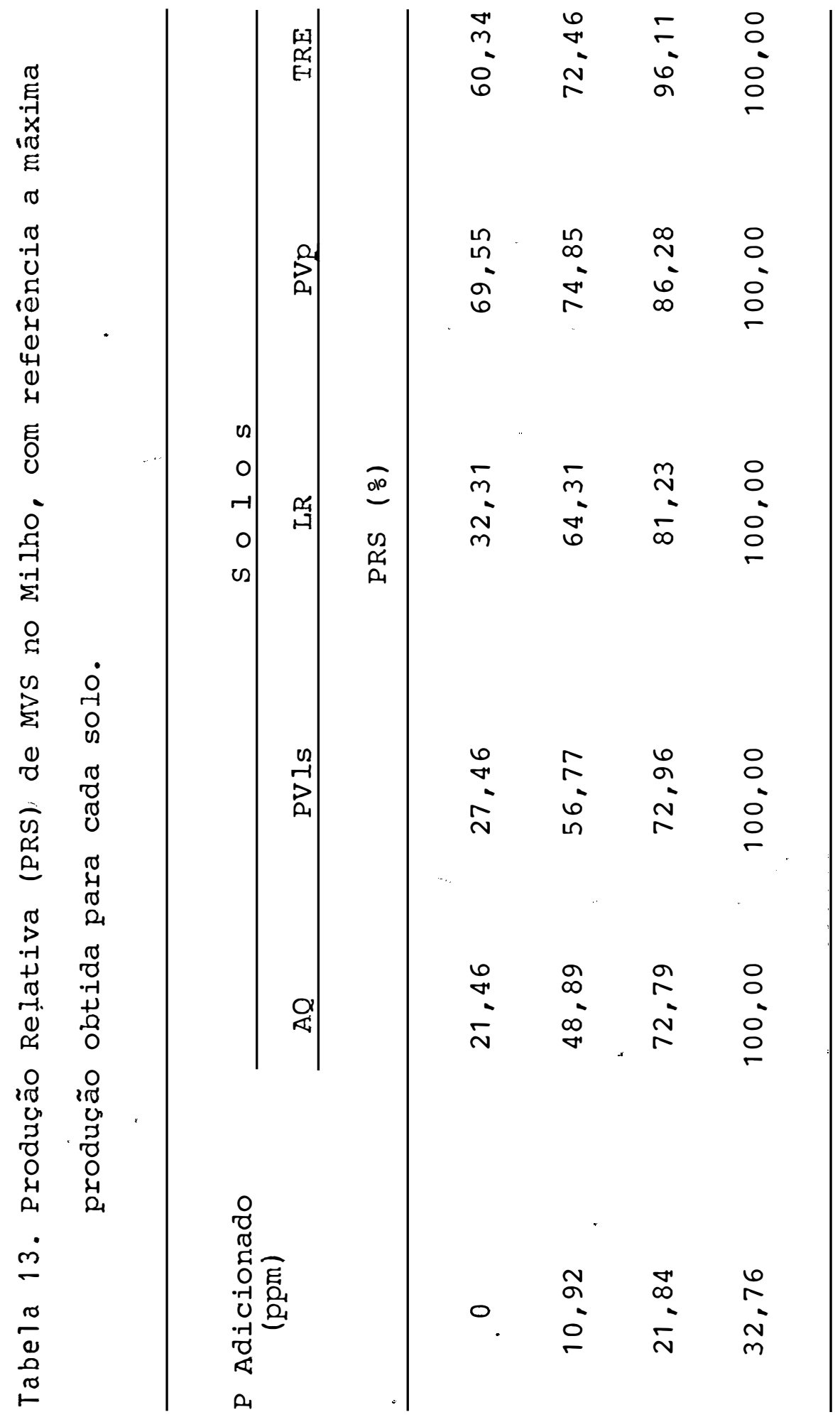


sendo que o PVp é o solo que apresenta a maior produção relativa para os niveis $\mathrm{P}_{0}$ e $\mathrm{P}_{1}$, e a TRE para $\circ \mathrm{P}_{2} \cdot \mathrm{O} L \mathrm{LR}$ apresen ta-se intermédio entre todos.

Na Tabela 14 observa-se que a maior produção foi conseguida na TRE ao nível de $\mathrm{P}_{3}$. Observa-se que a $\mathrm{AQ}, \mathrm{O}$ PVls e $O$ LR, não chegam a alcançar a produção mínima de MVS na TRE, sendo que $O$ PVp chega a essa produção só ao nível $\mathrm{P}_{3}$ de $\mathrm{P}$ adi cionado ao solo. Então pode-se deduzir que, os solos $\mathrm{AQ}$, PVls e LR, precisam de uma grande quantidade de $P$ adicionado para ảar quantidades pouco satisfatórias, de MVS, em relação a TRE.

Na Tabela 15 observa-se que, de forma similar ao Feijoeiro, no Milho a utilização eficiente foi muito baixa e bastante menor que no Feijoeiro.

Observa-se também, que o PVp foi o solo no qual o Milho teve menor utilização eficiente, sendo que no TRE foi a maior, e os solos PVls e LR apresentaram a mesma tendência. entre eles.

Ençuanto aos incrementos na Produção, observa-se que são muito menores aos obtidos para Feijoeiro, sendo que o solo que incrementou em maior quantidade a sua produção de MVS foi a $A Q$, no entanto essa quantidade, em termos absolu tos, represente menos da metade do obtido na TRE para o mesmo nivel de $\mathrm{P}$ adicionado. 
.76.

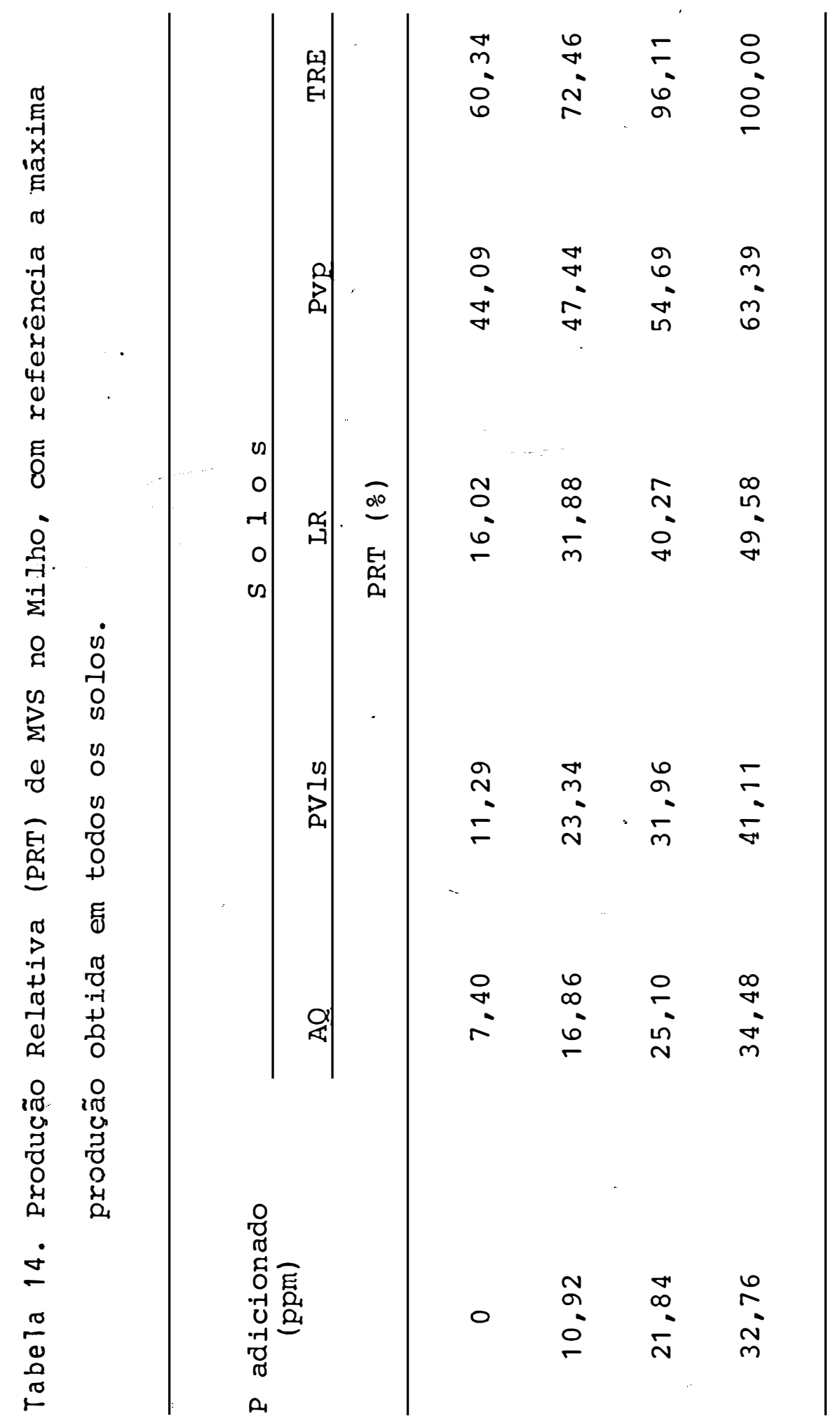




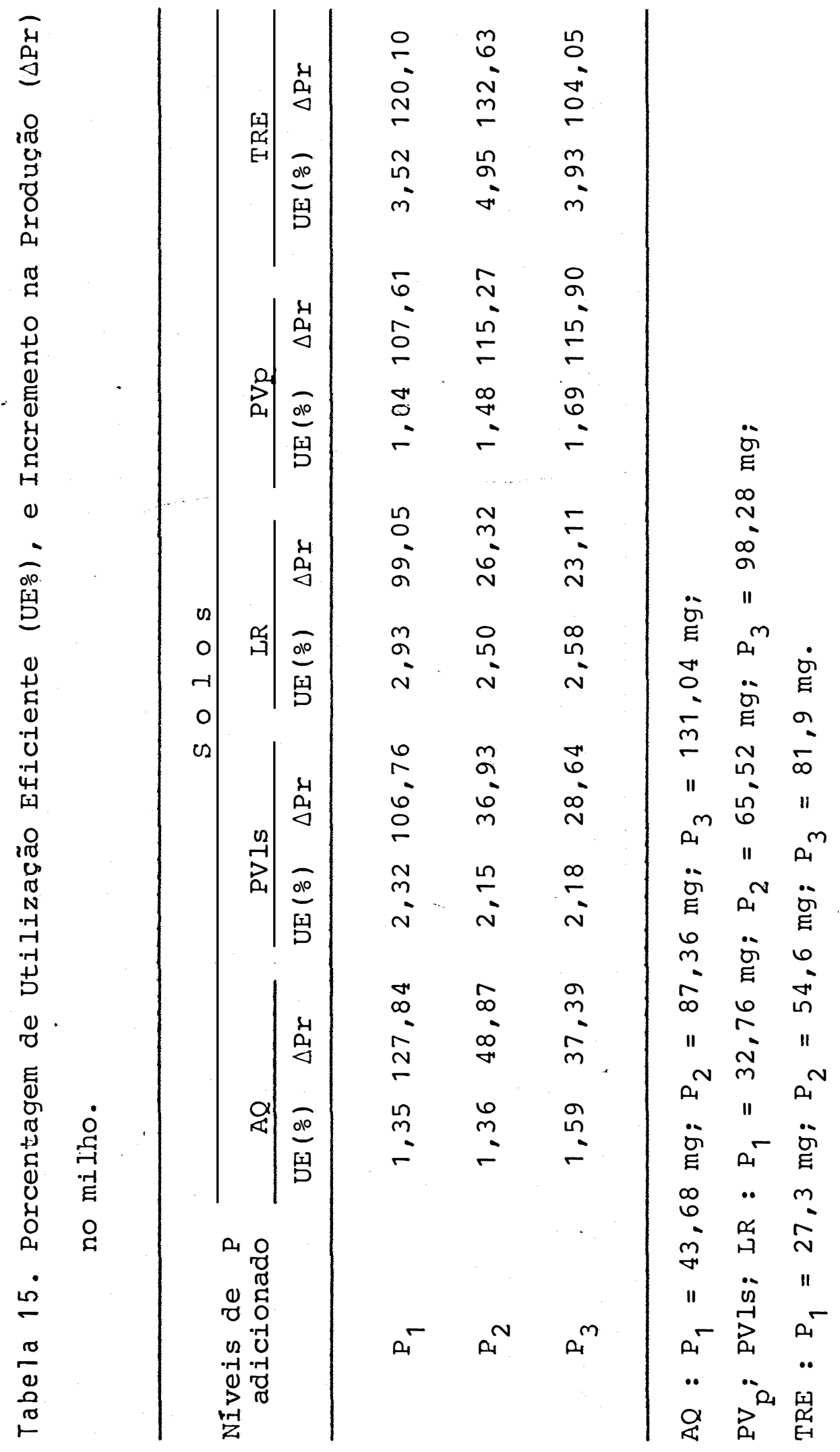


Vemos que os incrementos na produção de MVS no Milho, decrescem à medida que aumenta a quantidade absoluta de $\mathrm{P}$ solúvel nos solos (Tabela 3 ), e não guardando nenhuma correlação com referência ao P orgânico ou P total do solo, em termos de quantidades absolutas.

4.4. Correlações

4.4.1. Entre Matēria Vegetal Seca e Fósforo Solūvel no Solo, e entre o Fósforo Total na MVS e o Fósforo solūvel no solo

4.4.1.1. Feijoeiro

Na Tabela 16, tem-se os coeficientes de correlação obtidos entre a MVS produzida no feijoeiro, nos diferen tes solos, e o P solúvel obtido por diferentes métodos de aná lise, para os mesmos solos anteriores.

Observa-se que a sequência de ordens de grande za entre os coeficientes de correlação seria a seguinte segun do os métodos usados:

Bray $\mathrm{P}-1<$ Olsen < Bray $\mathrm{P}-2<$ Mehlich < IAC

Todos os coeficientes de correlação foram altą mente significativos $(P<0,01)$, e tem relação estreita com 
os valores do Teste de $\mathrm{F}$ dado na mesma Tabela.

Quando comparados estes valores, com os resultados das análises de $\mathrm{P}$ solúvel no solo (Tabela 3), podem-se fazer as seguintes observações: a ordem em que foram separados os diferentes extratores, segundo a sua capacidade extratora, não concorda exatamente com os resultados obtidos da correlação com a MVS produzida, já que, os método de IAC, e de Mehlich estão de acordo com a suposição de que, por ser os métodos que maior quantidade de $\mathrm{P}$ extrairam, deveriam ser os de melhor correlação: No entanto, o método de Bray P-1 não deu os resultados que poderiam ser esperados.

Os métodos que melhor resultado apresentaram nas correlações, são aqueles mais adequados para solos bastan te ácidos, como os usados neste experimento, sendo que o mê todo de olsen et alii, mais adequado para solos alcalinos ou ligeiramente ácidos, deu o menor coeficiente de correlação.

Por outra parte, todos os métodos apresentaram boa correlação com a MVS, considerando os dados da literatura cientifica a respeito, os quais consideram como boa uma corre lação significativa ao nível de $1 \%$, com um valor maior do que 0,7 para $r$.

Na Tabela 16, também apresentam-se os resultados das correlações entre a quantidade de $\mathrm{P}$ total na MVS de Feijoeiro, e a quantidạde de P solúvel extraido por diferen- 


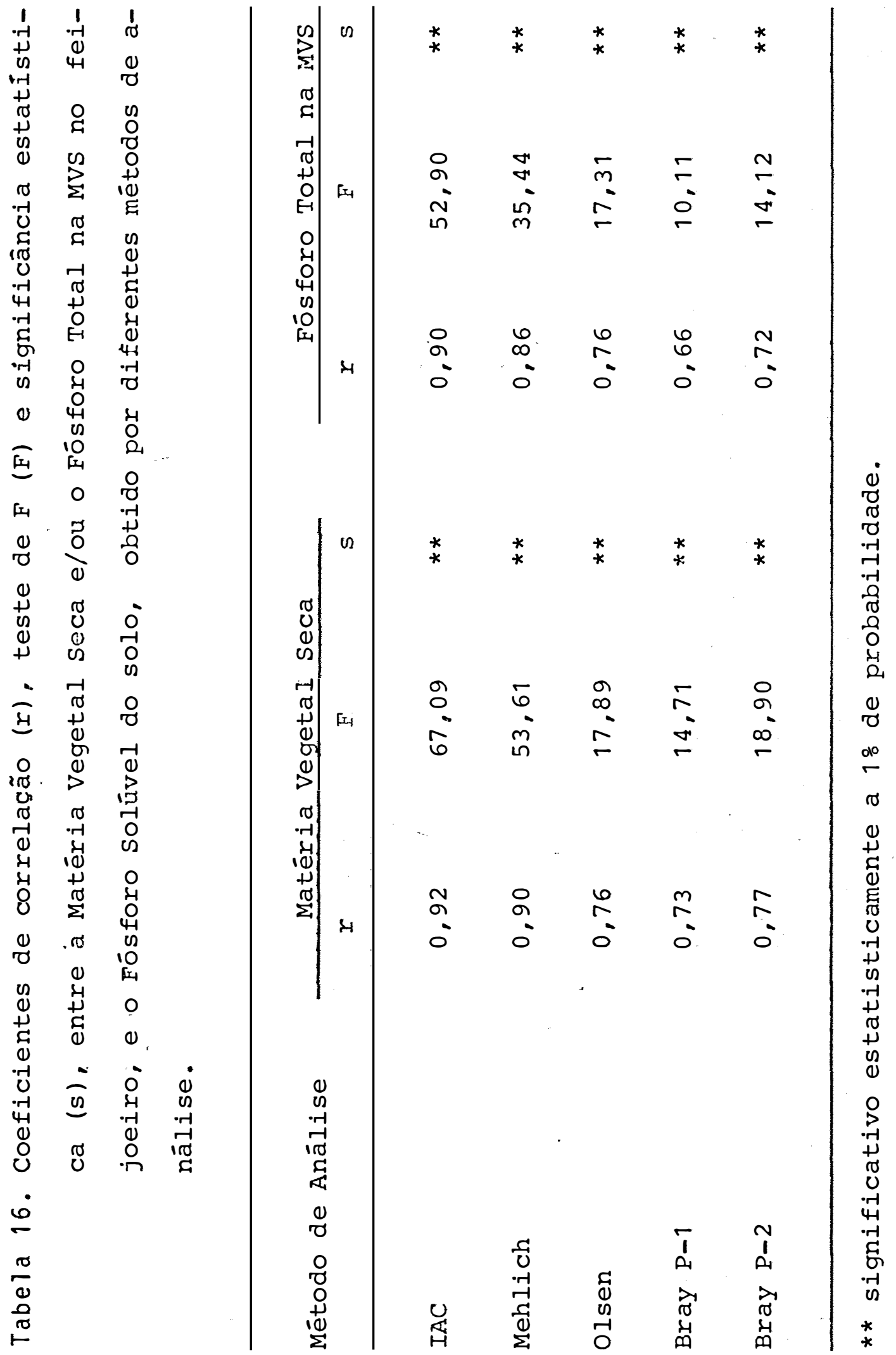


tes métodos de anālise, para os cinco solos do Estado de São Paulo.

Nesta Tabela, observa-se que a sequência crescente das ordens de grandeza dos coeficientes de correlação, segundo os métodos de análise usados, é a seguinte:

Bray $\mathrm{P}-1<$ Bray $\mathrm{P}-2<$ Olsen < Mehlich < IAC

Observa-se, de forma similar à correlação com a MVS, que os melhores métodos são os do IAC e Mehlich, de forma similar com o discutido anteriormente.

Também pode-se notar que o método de olsen, em bora seja um dos métoảos que menor quantidade de $\mathrm{P}$ solúvel ex traiu, apresenta coeficiente de correlação superior aos métodos de Bray P-1 e P-2, os quais, de forma geral, extrairam maior quantidade de $\mathrm{P}$ dos solos.

Devido ao anterior, poderia-se considerar que os extratores usados por Mehlich e por Catani (IAC), são os melhores para se estabelecer correlaçãa entre a MVS ou O P to tal na ivs de Feijoeiro, e a quantidade de $\mathrm{P}$ solúvel no solo.

\subsubsection{Milho}

Na Tabela 17, tem-se os coeficientes de correlação obtidos entre a MVS produzida pelo Milho com a quantida de de $\mathrm{P}$ solúvel extraído por diferentes extratores, assim co- 
.82 .

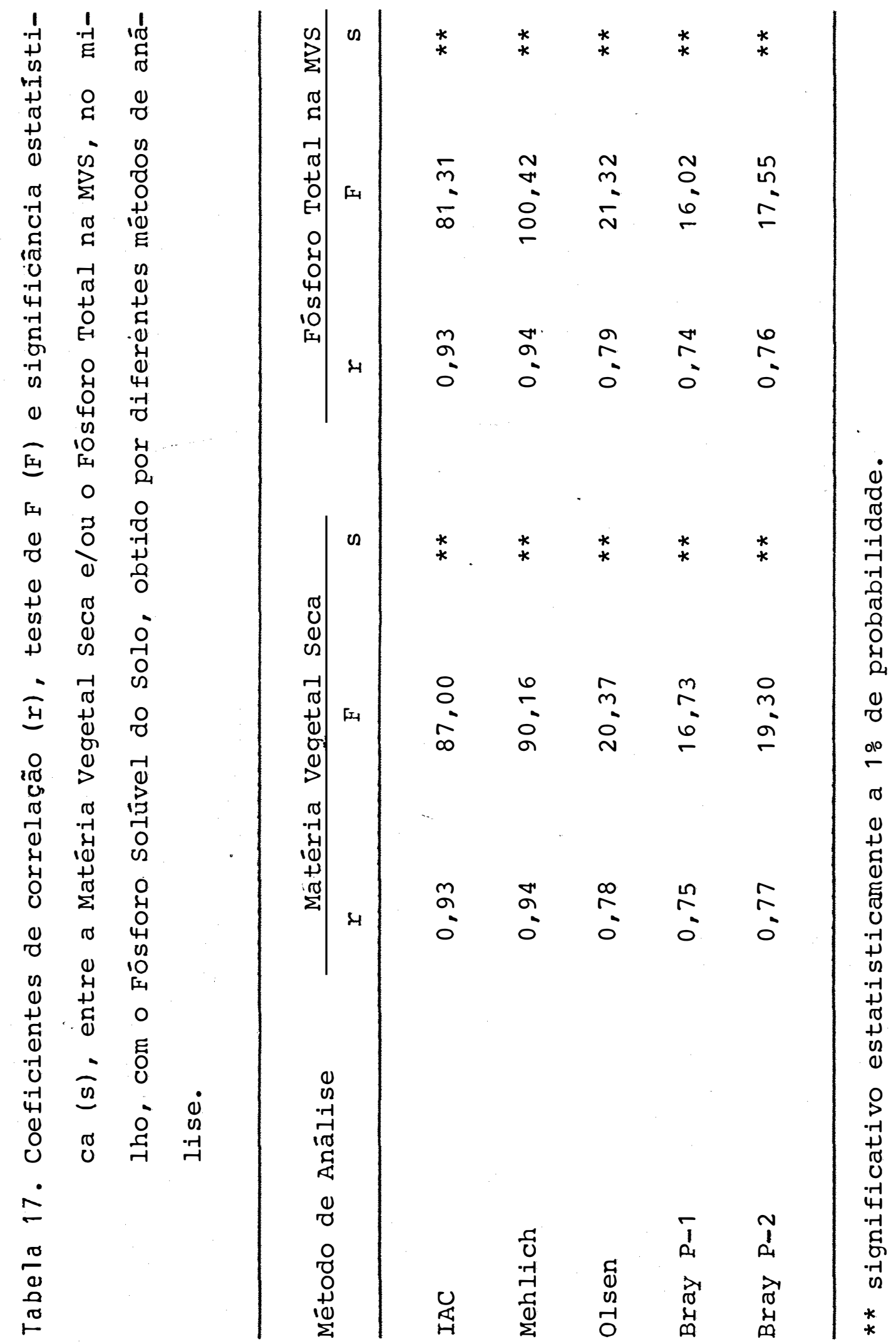


mo os coeficientes de correlação obtidos entre o P total na MVS de Milho, e o P solúvel do solo, extraído por diferentes métodos de análise.

Observa-se que tanto para a correlação com a MVS, quanto com o $\mathrm{P}$ total na MVS, os coeficientes de correlação cumprem com a seguinte ordem de grandeza:

$$
\text { Bray } \mathrm{P}-1<\operatorname{Bray} \mathrm{P}-2^{\circ}<\text { Olsen }<\text { IAC < Mehlich }
$$

Observa-se que, de igual forma que para o Feijoeiro, os extratores que deram a melhor correlação da-se com os melhores métodos para o tipo de solo empregado no experimento:

Também observa-se que os métodos do IAC e Mehlich apresentam valores quase iquais, de igual forma que os métodos de Bray P-1, Bray P-2 e Olsen, apresentam valores mui to próximos, mas diferem bastante os dois grupos entre si, pe lo qual, no Milho, pode-se supor com maior certeza, que os mé todos de Mehlich e IAC são os mais indicados. 
4.4.2. Correlações entre Matēria Vegetal Seca e Fósfo ro Orgânico no Solo, e entre Fósforo Total na MVS e Fósforo Orgānico no solo

\subsubsection{Feijoeiro}

Na Tabela 18, tem-se os coeficientes de correlação obtidos entre a MVS produzida pelo Feijoeiro, nos diferentes solos, e o Fósforo Orgânico obtido do solo por diferentes métodos de análise, assim como os coeficientes de correlação entre fósforo Total na MVS de Feijoeiro e Fósforo orgânico do Solo.

Observa-se por esses resultados que, tanto 0 método de Saunders e Williams como o de Mehta et alii são equivalentes, já que apresentaram coeficientes de correlação similares.

Também cabe destacar que a correlação não foi tão significativa quanto com $\circ \mathrm{P}$ solúvel, pois os coeficientes de correlação são significativos só ao nível de 5\% de pró bailidade, sendo que para o $\mathrm{P}$ solúvel, além de ter-se valores absolutos mais altos, a significância é ao nível de $1 \%$ de pro babilidade.

Do anterior, pode-se deduzir que O P orgânico não apresenta uma boa correlação com as piantas de Feijoeiro para o tipo de solos ácidos, e, em geral, com pouca matéria orgânica, empregados neste experimento. 
.85

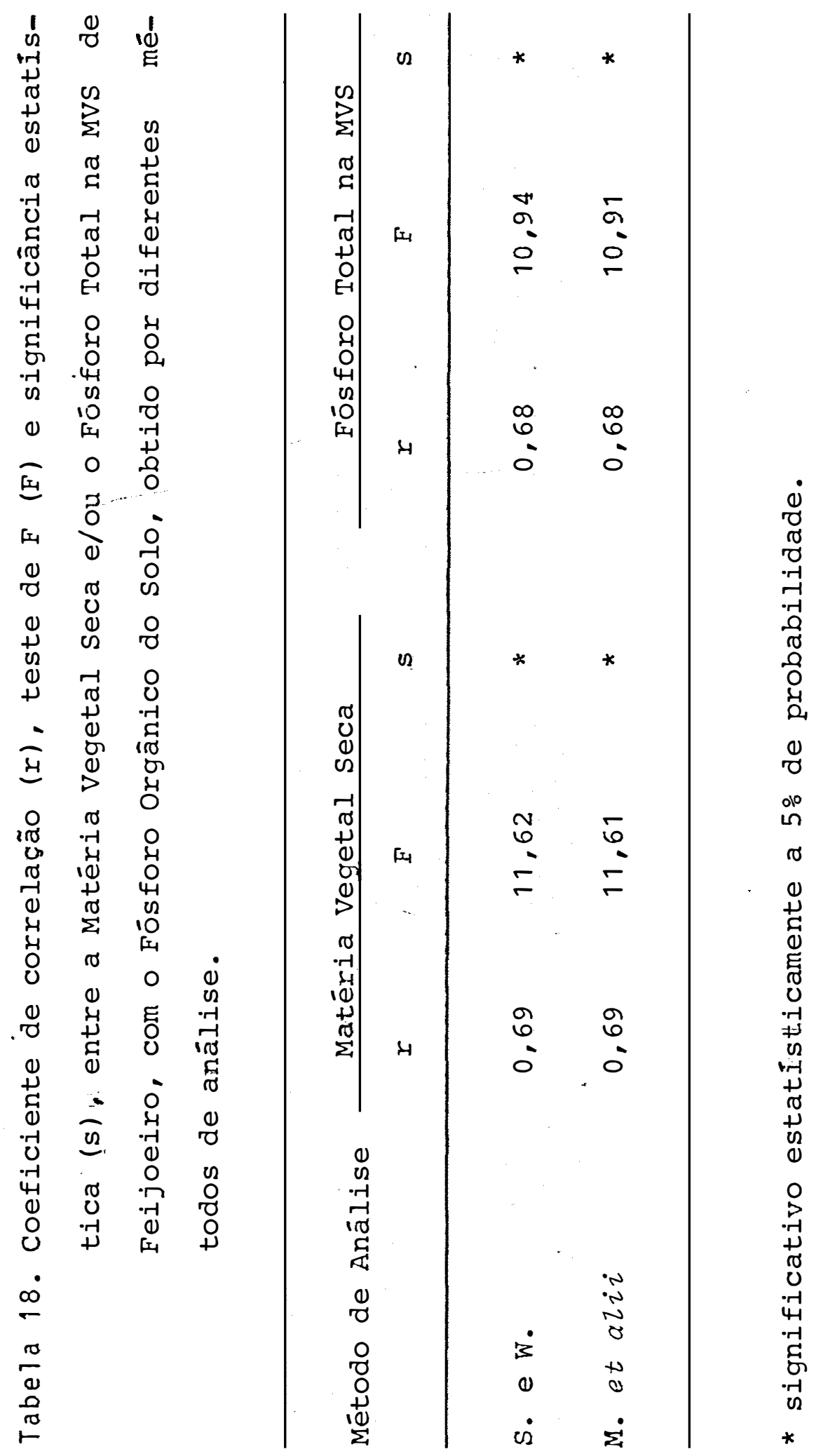


4.4.2.2. Milho

Na Tabela 19, tem-se os coeficientes de correlação obtidos entre a MVS produzida pelo Milho, nos diferentes solos, e o Fósforo Orgânico do Solo obtido por diferentes métodos de análise, assim como os coeficientes de correlação entre Fósforo Total na MVS do Milho e Fósforo Orgânico do So10 .

Neste caso, valern as mesmas considerações que para o Feijoeiro, ressaltando que os valores absolutos para os coeficientes de correlação com a MVS do Milho são menores que os do Feijoeiro, e os valores absolutos com a P Total na MVS, são bem inferiores a os obtidos com Feijoeiro.

4.4.3. Correlacões entre Matēria Vegetal Seca e Fósfó ro Total no Solo, e entre Fósforo Total na MVS e Fósforo Total no solo

4.4.3.1. Feijoeiro

Na Tabela 20, tem-se os coeficientes de correlação obtidos entre a Matéria Vegetal Seca produzida pelo Feí joeiro, e o Fósforo Total do solo obtido por diferentes métodos de análise, em ambos casos para os cinco solos em estudo, assim como também os coeficientes de correlação entre o Fósfo ro Total na MVS de Feijoeiro e o Fósforo Total do Solo. 
.87 .

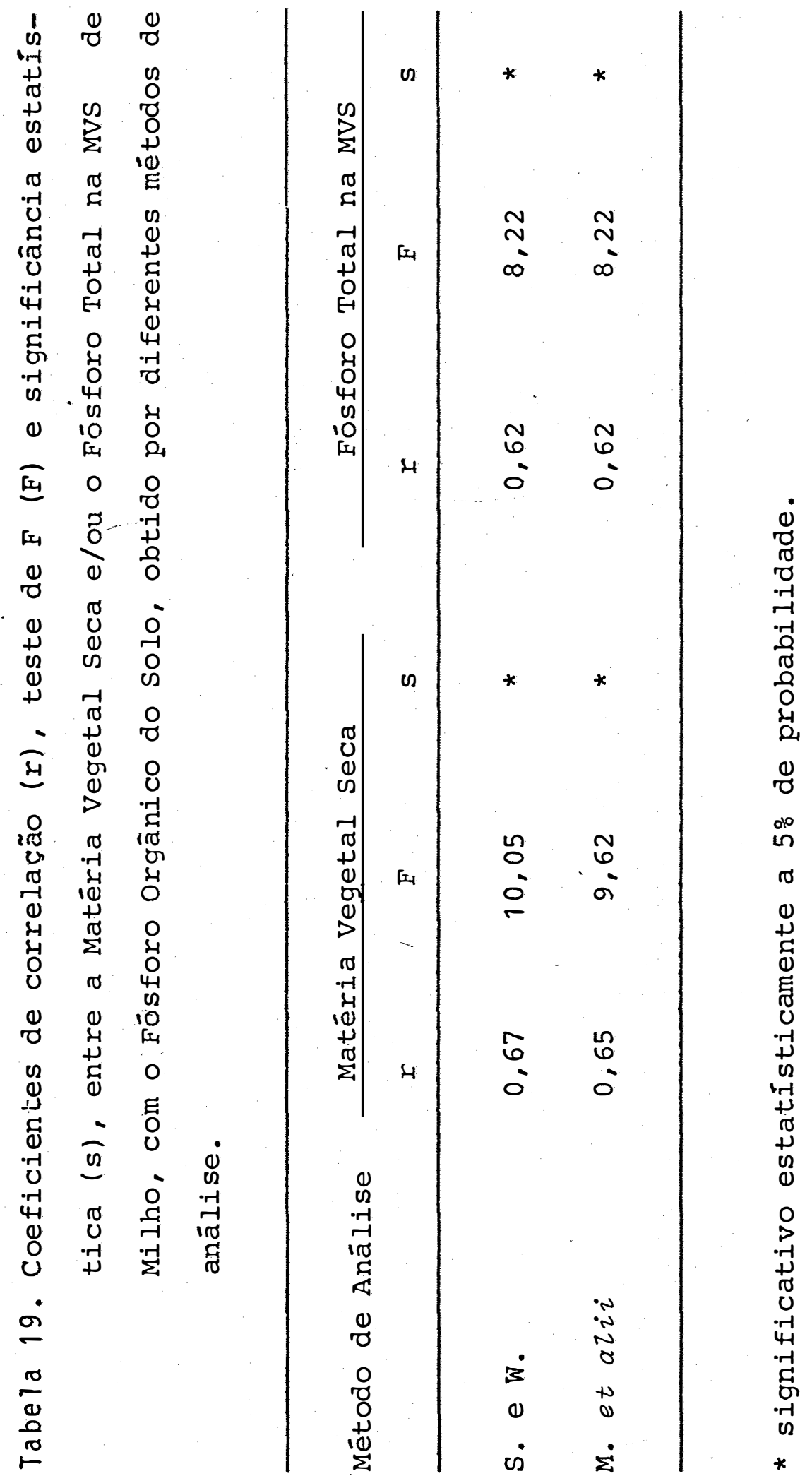


.88

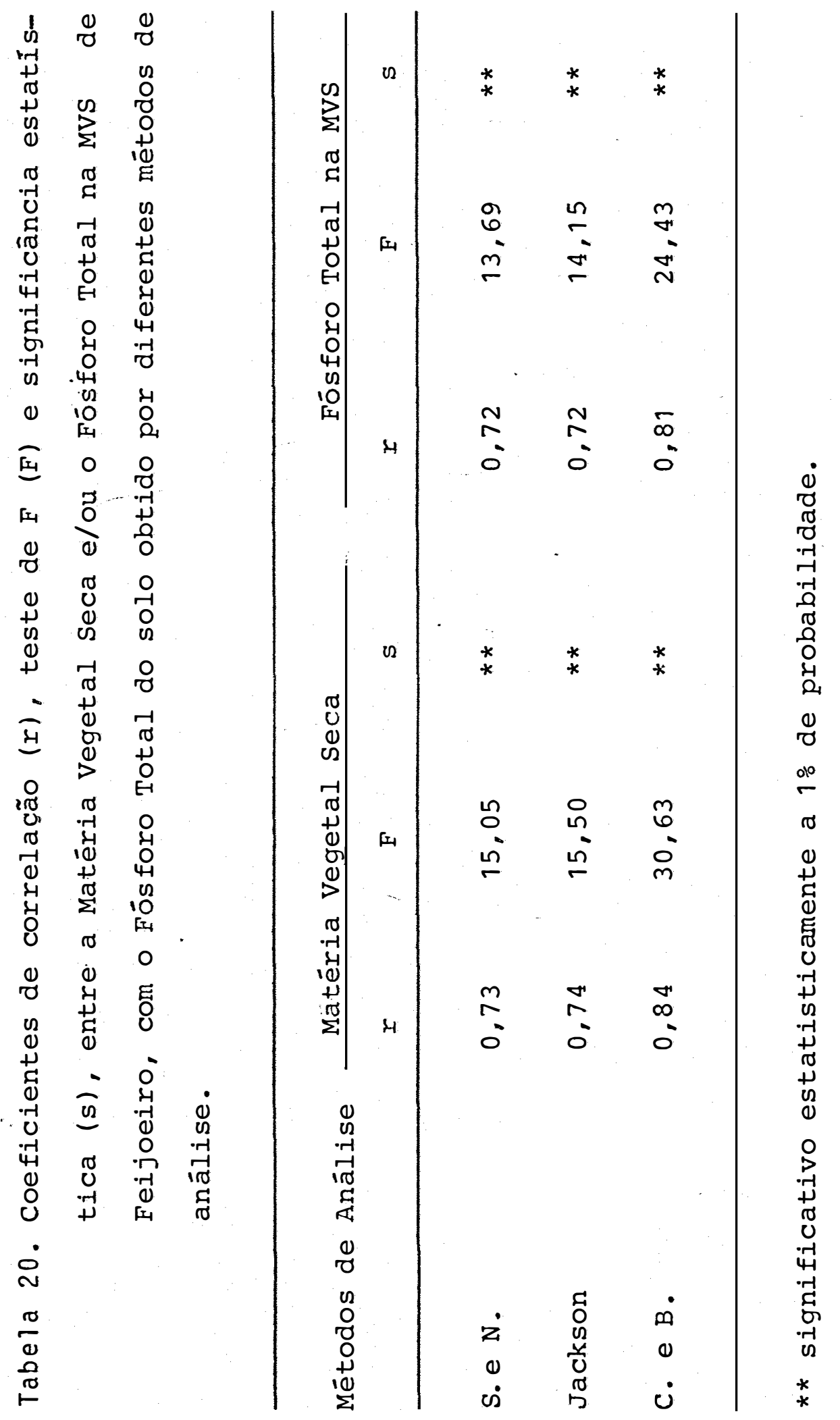


Observa-se nesses dados que os valores absolutos dos coeficientes de correlação, tanto com o MVS como com - P Total na MVS, são muito próximos, tendo-se uma alta signi ficância estatística $(P<0,01)$, o qual não acontece com $\circ P$ orgânico.

Comparando estes valores, com os obtidos para O P orgânico do solo por diferentes métodos (Tabela 4), pode-se notar que o método de Catani e Bataglia foi o que apresen tou melhor correlação, no entanto o método não é bom para a determinação do P Total no solo, quando comparado com os outros dois. Devido ao exposto anteriormente, deve-se tomar com reserva os valores dados nestas correlações, já que não concordam com os valores relativos obtidos para o Fósforo Total no solo.

Por outra parte, os métodos de Sommers e Nelson e de Jackson, apresentam-se equivalentes, tanto na determinação do $\mathrm{P}$ Total do Solo, quanto nas correlações com a MVS de Feijoeiro e o P Total na MVS.

\section{$4 \cdot 4 \cdot 3 \cdot 2$. Mitho}

Na Tabela 21, apresentam-se os coeficientes de correlação entre a Matéria Vegetal Seca produzida pelo Milho, nos cinco diferentes solos, e o Fósforo Total obtido para essessolos por diferentes métodos de análise, assim como os coe ficientes de correlaçãó entre o Fósforo Total na MVS de Milho, 


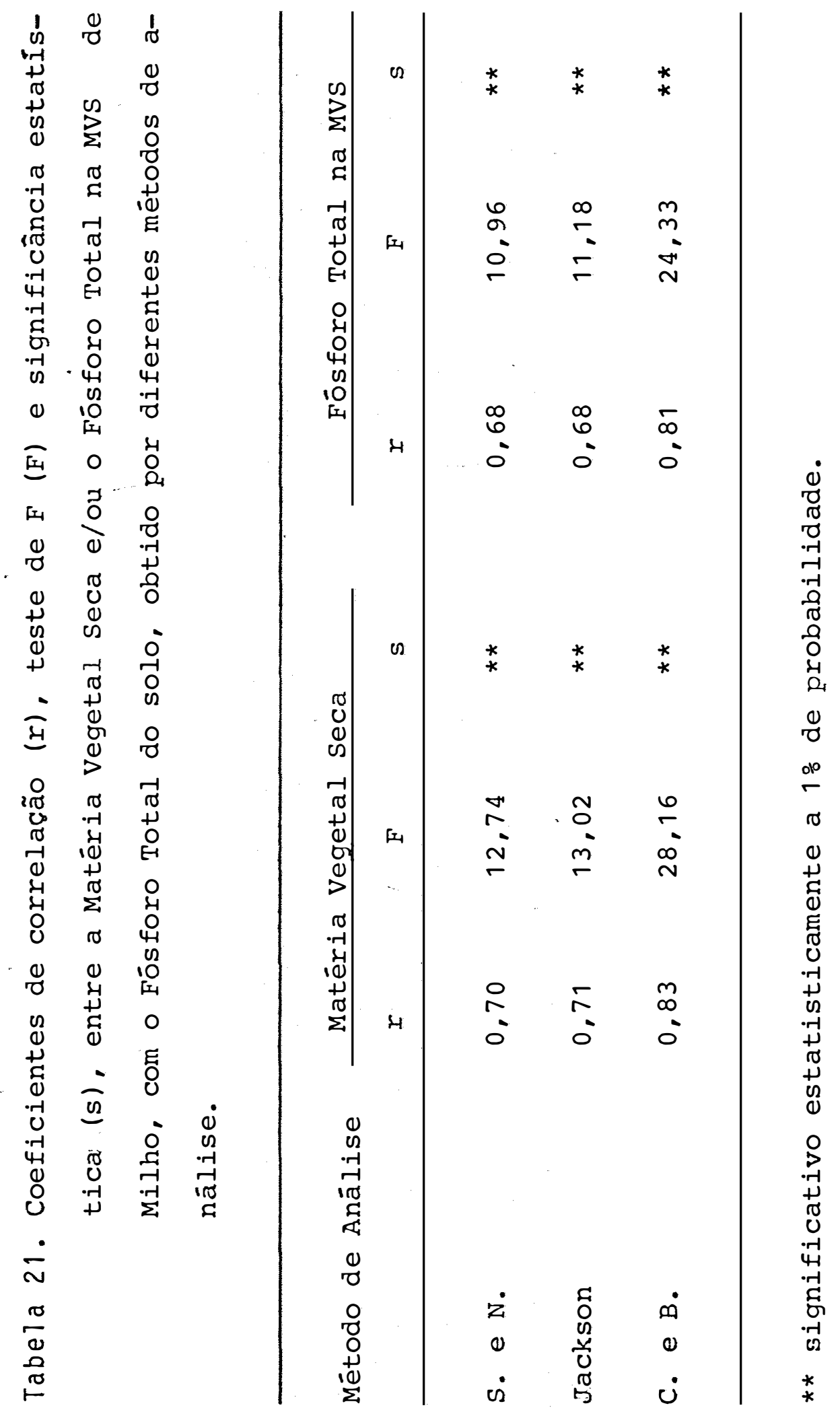


e o p Total do Solo.

Neste caso valem as mesmas considerações feitas para o Feijoeiro,ressaltando que os valores absolutos dos coeficientes de correlação para o Milho, são um pouco inferio res aos obtidos para o Feijoeiro, no entanto apresentam uma alta significância estatística $(P<0,01)$.

\subsubsection{Correlação entre Matēria Vegetal Seca e'Fōsfo- ro Adicionado ao solo, e entre Fösforo Total na MVS e Fósforo Adicionado ao Solo}

\subsubsection{Feijoeiro}

Na Tabela 22, observam-se os coeficientes de correlação obtidos entre a Matéria Vegetal Seca produzida pelo Feijoeiro, em cada solo, e o Fósforo Adicionado ao Solo, assim comó os coeficientes de correlação entre o Fósforo To- . tal na MVS de Feijoeiro, e o P adicionado ao solo.

Dos dados apresentados, observa-se que em todos os solos deu-se uma correlação altamente significativa, ao nível de 1\% de probabilidade, sendo que os válores obtidos com o Fósforo Total na MVS, são ligeiramente melhores que os obtidos com MVS, no entanto todos esses valores estão na ordem de 0,98 ou mais, exceto a correlação no PVp entre MVS de Feijoeiro e P adicionado, no qual o valor cai para 0,93. 
Tabela 22. Coeficientes de correlação ( $r$ ), teste de $F(F)$ e significância estatística (s), entre a Matēria Vegetal Seca, e o Fósforo Total na MVS em Feijoeiro, com os diferentes nỉveis de Fósforo Adicionado ao solo, para cada tipo de solo.

Solo

Matéria Vegetal Seca

Fósforo Total na MVS

\begin{tabular}{|c|c|c|c|}
\hline \multirow[t]{3}{*}{$\mathrm{AQ}$} & $r$ & 0,988 & 0,995 \\
\hline & $\mathrm{F}$ & 78,62 & 207,67 \\
\hline & $\mathbf{S}$ & $\star \star$ & $\star \star$ \\
\hline \multirow[t]{3}{*}{ PVls } & $r$ & 0,992 & 0,995 \\
\hline & $\mathrm{F}$ & 120,76 & 195,60 \\
\hline & $\mathbf{s}$ & $\star \star$ & $\star \star$ \\
\hline \multirow[t]{3}{*}{ LR } & $r$ & 0,984 & 0,988 \\
\hline & $\mathrm{F}$ & 60,05 & 79,71 \\
\hline & $\mathbf{s}$ & $\star \star$ & $\star \star$ \\
\hline \multirow[t]{3}{*}{$P V p$} & $r$ & 0,932 & 0,992 \\
\hline & $\mathrm{F}$ & 13,18 & 124,61 \\
\hline & $\mathbf{s}$ & $\star *$ & $* *$ \\
\hline \multirow[t]{3}{*}{ TRE } & $r$ & 0,999 & 0,998 \\
\hline & $\mathrm{F}$ & 794,93 & 404,60 \\
\hline & s & $\star *$ & $\star \star$ \\
\hline
\end{tabular}

** significativo estatisticamente a 1\% de probabilidade. 
Pelo anterior, pode-se deduzir que o Feijoeiro respondeu significativamente a adubação fosfatada, tanto na produção de MVS, quanto na quantidade de $\mathrm{P}$ Total na MVS.

\subsubsection{Milho}

$\mathrm{Na}$ Tabela 23, observam-se os coeficientes de correlação entre a Matéria Vegetal. Seca produzida pelo Milho, para cada solo, e o Fósforo Adicionado ao Solo, assim como também os coeficientes de correlação entre o Fósforo Total na MVS de Milho e o Fósforo Adicionado ao Solo.

De forma similar ao Feijoeiro, no Milho se obtiveram coeficientes de correlação altamente significativos, com significāncia estatística a 1\% de probabilidade, para todos os solos estudados.

Os valores absolutos de $r$ em todos os solos, ao contrário do Feijoeiro, estão bastante próximos da unidade, sendo que o menor valor obtido é de 0,967 com a TRE.

Assim como no caso do Feijoeiro, pode-se dizer que o Milhó respondeu significativamente a adubação fosfatada, tanto na produção de MVS, quanto na quantidade de $\mathrm{P}$ total na MVS. 
Tabela 23. Coeficientes de correlação (r), Teste de F (F) e significância estatística (s), entre a Matéria Vegetal Seca, e o Fósforo Total na MVS em Milho, com os diferentes níveis de Fósforo Adicionado ao So1o, para cada tipo de solo.

\begin{tabular}{|c|c|c|c|}
\hline $\begin{array}{c}\text { Solo } \\
. \\
\end{array}$ & - & Matéria Vegetal seca & Fósforo Total na MVS \\
\hline \multirow[t]{3}{*}{$\mathrm{AQ}$} & $r$ & 0,999 & 0,997 \\
\hline & $\mathrm{F}$ & 2848,71 & 336,44 \\
\hline & $\mathbf{s}$ & ** & $* *$ \\
\hline \multirow[t]{3}{*}{ PVls } & $r$ & 0,997 & 0,999 \\
\hline & $F$ & 333,29 & 2462,31 \\
\hline & $\mathbf{s}$ & $\star *$ & ** \\
\hline \multirow[t]{3}{*}{ LR } & $r$ & 0,988 & 0,998 \\
\hline & $F$ & 83,33 & 514,10 \\
\hline & $\mathbf{s}$ & ** & $\star *$ \\
\hline \multirow[t]{3}{*}{$\mathrm{PVp}$} & $r$ & 0,983 & 0,989 \\
\hline & $F$ & 55,15 & 94,60 \\
\hline & $\mathbf{s}$. & $* *$ & ** \\
\hline \multirow[t]{3}{*}{ TRE } & $r$ & 0,969 & 0,981 \\
\hline & $F$ & 30,89 & 52,32 \\
\hline & $\mathbf{s}$ & $\star *$ & $* *$ \\
\hline
\end{tabular}

** significativa estatisticamente a 1\% de probabilidade. 
4.4.5. Correlação entre a Matēria Vegetal Seca produzida e a quantidade de Fósforo Total na MVS, para cada nĩvel de Fósforo Adicionado ao Solo

\subsubsection{Feijoeiro}

Na Tabela 24, tem-se os valores obtidos para os coeficientes de correlação entre a Matéria Vegetal Seca produzida pelo Feijoeiro, e a quantidade de Fósforo Total nes sa MVS.

Segundo os dados anotados, os valores absolutos dos coeficientes de correlação, estão na seguinte ordem crescente, segundo o nível de $\mathrm{P}$ adicionado ao solo:

$$
\mathrm{P}_{1}<\mathrm{P}_{2}<\mathrm{P}_{3}<\mathrm{P}_{0}
$$

Observa-se que estes dados concordam com os de quantidade de fósforo absorvido pela planta a cada nível de $\mathrm{P}$ acidionado ao solo, para todos os solos, no entanto, esses vạ lores de r são altamente significativos ao nivel de $1 \%$ de pro babilidade, e as suas diferenças reais são muito baixas, pelo quai pode-se considerar que a todos os niveis, a quantidade de Fósforo na Planta, se correlacionou muito bem com a matéria vegetal seca produzida no Feijoeiro.

\subsubsection{Milho}

Na Tabela 25, tem-se os valores obtidos para 
Tabela 24. Coeficientes de correlação (r), teste de $F(F)$ e significância estatística (s), entre a Matéria Vegetal seca e o Fósforo Total na MVS de Feijoeiro, para cada nível de Fósforo Adicionado ao Solo.

\begin{tabular}{|c|c|c|c|c|}
\hline & \multicolumn{4}{|c|}{$\mathrm{P}$ adicionado (ppm) } \\
\hline & 0 & 10,92 & 21,84 & 32,76 \\
\hline$r$ & 0,986 & 0,946 & 0,953 & 0,982 \\
\hline F & 439,45 & 110,33 & 129,67 & 250,69 \\
\hline $\mathbf{s}$ & $\star \star$ & $\star *$ & $\star \star$ & $\star *$ \\
\hline
\end{tabular}

** significativo estatisticamente a 1\% de probabilidade.

Tabela 25. Coeficientes de correlação (r), teste de $F(F)$ e significância estatística (s), entre a Matēria Vegetal Seca e o Fósforo Total na MVS de Milho, para cada nível de Fósforo Adicionado ao Solo.

\begin{tabular}{|c|c|c|c|c|}
\hline \multirow[t]{2}{*}{ - } & \multicolumn{4}{|c|}{$\mathrm{p}$ adicionado (ppm) } \\
\hline & 0 & 10,92 & 21,84 & 32,76 \\
\hline$r$ & 0,997 & 0,987 & 0,995 & 0,998 \\
\hline$F$ & 2120,11 & 500,82 & 1165,68 & 2680,58 \\
\hline $\mathbf{s}$ & $\star \star$ & $\star \star$ & $\star \star$ & $\star *$ \\
\hline
\end{tabular}

** significativo estatisticamente a $1 \%$ de probabilidade. 
os coeficientes de correlação entre a Matéria Vegetal Seca produzida pelo Milho, e a quantidade de Fósforo Total nessa MVS.

Segundo os dados anotados, observa-se que praticamente não existe diferença entre os valores de $r$ para cada nível de $\mathrm{P}$ adicionado do solo, sendo que apresentam uma al ta significância estatística ao nível de $1 \%$ de probabilidade, para todos os casos.

Pode-se dizer que o Milho apresentou melhor correlação entre a MVS e o P contido nela, a todos os níveis de $\mathrm{P}$ aplicado, pelo qual o comportamento do milho em casa de vegetação é superior ao Feijoeiro para teste de Fósforo.

4.5. Sugestões para pesquisas posteriores

Com base nos resultados obtidos no presente trabalho, e com o fim de esclerecer certas dúvidas, bem como garantir o prosseguimento dessa linha. de pesquisa, a qual visa esclaṛecer o comporiamento do fósforo frente a diferentes extratores químicos, e diferentes classes de fósforo no solo, e sua relação direta na absorção pelas plantas, pretende-se realizar, na Venezuela, as seguintes pesquisas:

a. Instalação de experimentos de estufa e de campo, com plantas diferentes, e para diferentes tipos de so- 
los, a fim de obter as correlações entre as classes de fósforo no solo e a absorção do fósforo pela planta.

b. Instalar experimentos ampliando o número de extratores químicos usados para as diferentes classes de fósforo no solo, visando encontrar os melhores extratores.

- c. Efetuar o fracionamento do fósforo para os solos estudados, e estudar a correlação dos tipos de fósforo no solo com os métodos de extração para cada classe de fósforo, assim como as suas correlações com as plantas, e o fósforo absorvido por elas.

d. Utilizar o maior número de extratores, para as diferentes classes de $\mathrm{P}$, no maior número possível de solos, bem caracterizados mineralógica, física e quimicamente, para assim poder fazer extrapolações significativas.

e. Realizar no maior número possivel de solos, estudos da cinética de adsorção e desorção de $\mathrm{P}$ nestes solos. 
5. CONCLUSOEES

1. Dos extratores utilizados para determinar fósforo solúvel, os melhores foram os de IAC $\left(\mathrm{H}_{2} \mathrm{SO}_{4} 0,05 \mathrm{~N}\right)$ e Mehlich $\left(\mathrm{H}_{2} \mathrm{SO}_{4} 0,025 \mathrm{~N}+\mathrm{HCl} 0,05 \mathrm{~N}\right)$, em termos de quantidade de $\mathrm{P}$ extraído.

2. Os dois extratores utilizados para determinar P orgânico, Mehta et alii (extração com HCl e NaOH) e Saunders e Williams (ignição e extração com $\mathrm{H}_{2} \mathrm{SO}_{4}$ ), foram equivalentes no referente a quantidade de $\mathrm{P}$ extraído.

3. Os métodos de Sommers e Nelson (digestão perclórical e Jackson (fusão com $\mathrm{Na}_{2} \mathrm{CO}_{3}$ e extração com $\mathrm{H}_{2} \mathrm{SO}_{4}$ ) foram os melhores no que diz respeito a quantidade de $\mathrm{P}$ extrá ída.

4. De forma geral, houve respostas, tanto no Milho como no Feijoeiro, ao $\mathrm{P}$ adicionado nos três níveis para 
os cinco solos, tanto na Matéria Vegetal Seca produzida, como no $P$ total na MVS. Convém destacar os solos AQ, PVls e LR com uma maior resposta ao $\mathrm{P}$ adicionado. Isto foi confirmado pelos coeficientes de correlação.

5. Para as duas culturas, em todos os solos e todos os níveis de $\mathrm{P}$ aplicado, a porcentagem de Utilização Efetiva de $\mathrm{P}$ foi baixa, menos do que 108 sendo que no Milho foi menor que no Feijoeiro. No Feijoeiro, a melhor porcentagem de Utilização Efetiva foi no LR $(7,148)$ e no Milho foi na $\operatorname{TRE}(4,95 \%)$.

6. Nos extratores de P solúvel, as melhores correlações com a MVS produzida e com o P total na MVS, foram com os extratores do IAC e do Mehlich, para as duas culturas $\left(r=0,94^{* *}\right)$.

7. Os dois extratores usados para $P$ orgânico, deram as mesmas correlações com Matéria Vegetal Seca e com $\mathrm{P}$ total na MVS, nas duas culturas $(r=0,69 *)$.

8. No referente aos Extratores para P total, não pode-se ter uma conclusão certa, devido a que o extrator menos eficiente (Catani e Bataglia) foi o que deu a melhor correlação $\left(r=0,83^{*}\right)$.

9. Em todos os niveis de $\mathrm{P}$ adicionado ao solo, houve uma correlação muito boa entre a Matéria Vegetal Seca produzida, e o $\mathrm{P}$ total na MVS, tanto para o Feijoeiro como pa ra o Milho. 
6. LITERATURA CITADA

ADAMS, A.P., M.W. BATHOLOMEU e F.E. CLARCK, 1954. Measurement of nucleic acids components in soil. Soir Sci. Soc. Amer. Proc., 18: 40-46.

ALEXANDER, T.G. e J.A. ROBERTSON, 1972. EDTA extractable phosphorus in relation to available and inorganic phosphorus forms in soils. Soil Sci。, 114: 69-72.

AMER, F., D.R. BOULDIN, C.A. BLACK e F.R. DUKE, 1955. Characterization of soil phosphorus by anion-exchange resin absorption and ${ }^{32} \mathrm{P}$ equilibration. $\mathrm{Pl}$. Soil, 6: $391-$ -408 .

ANDERSON, A., 1975. Relative efficiency of nine different soil extractants. Sw. J. Agr. Res。, 5 (3): 125-135. ANDERSON, G., 1961. A partial fractionation of alkali-soluble soil organic phosphate. J. Soil Sci., 12: 276-285 .

ANDERSON, G., 1967. Soir Biochemistry, A.D. McLaren e G.H. Peterson, eds., pp. 67-90, Dekker, New York.

ANDERSON, G., 1970. The isolation of nucleoside diphosphates from alkaline extract of soil. J. Soir Sci., 21:96-105. 
ANDERSON, G. e R.J. HANCE, 1963. Investigation of an organic phosphorus component of fulvic acid. PI. Soil, XIX (3) 296-303.

ANDERSON, G. e R.E. MALCOM, 1974. The nature of alkali-soluble soil organic phosphates. J. Soil Sci., 25: 282-297 .

ANGHINONI , I e H. BOHNEN, 1972. Avaliação da disponibilidade de fósforo para os solos do Estado do Rio Grande do Sul. Agron. Sulriograndense, Porto Alegre, 10(1): 127-136.

AWAN, A.B., 1964. Effect of lime on availability of phosphorus in Zamorano soils. Soil Sci. Soc. Am. Proc., .28 (5): 672-673.

BAHIA FILHO, A.F. de C., 1974. Fósforo em latossolos do Estạ do de Minas Gerais: intensidade, capacidade tampão e quantidade de fósforo "disponivel" e crescimento vegetal. Viçosa, Universidade Federal de Viçosa, 69 p. (Dissertação de Mestrado).

BALERDI, F., L. MULLER e H.W. FASSBENDER, 1968. Estudio del fósforo en suelos de América Central. III. Comparación de cinco métodos químicos de análises de fósforo disponible. Turrialba, 18(4): 348-360.

BIASI, J. A avaliasão do fösforo relacionado a diversos extratores químicos em solos de Sarta Catarina. Piracicaba, 1978. 181 p. Dissertação de Mestrado. Universidade de São Paulo. Escola Superior de Agricultura "Luiz de Queiroz".

BIRCH, H.F., 1961. Phosphorus transformations during plant decomposition. Pl. Soir, $\underline{\mathrm{XV}}(4): 347-366$.

BITTENCOURT, V.C. de, J. ORLANDO e E. ZAMBELLO, 1978. Determination of available $\mathrm{P}$ for sugar cane in tropical soils by extraction with $0,5 \mathrm{~N}$ sulphuric acid. In Proceedings $16^{\text {th }}$ Congress International Society of Sugar Cane Technologists, Brazil 1977. 1175-1186. 
BLACK, C.A. e C.A.I. GORING, 1953. Organic phosphorus in soils. In: Soil and fertilizer phosphorus. Pierre W.H. and A.G. Norman, eds. Academic Press Inc., New York, pp. $123-152$.

BORNEMISZA, E., 1966. Organic phosphorus in tropical soils. Turrialba. 16: 33-38.

BOWER, C.A., 1949. Studies on the forms and availability of soil organic phosphorus. Iowa Agr. Exp。St。Res., Bulletim no 362 , p. 33 .

BRAGA, J.M., A.F.C. BAHIA, G.E. FRANÇA, R.G. HANSEN, T. HARA, J.F. MENDES, A.M. RESENDE e P.R.R.S. SANTOS, 1976. Calibração de análises químicas do solo e caracterização da curva de resposta da soja para o calcário e fósforo. Base para utilização Agropecuária. In: Simpósio sobre Cerrado, 6, Brasilia, $16 \mathrm{p}$.

BRAGA, J.M. e B.V. DEFELIPO, 1972a. Relações entre formas de $\mathrm{P}$ inorgânico, $\mathrm{P}$ disponível e material vegetal, em solos sob vegetação de cerrado. I: Trabalho de Laboratório. $R$. Ceres. Viçosa, 19(102): 124-136.

BRAGA, J.M. e B.V. DEFELIPO, 1972b. Relações entre formas de $P$ disponível. e material vegetal em solos sob vegetação de cerrado. II: Trabalho em estufa. R. Ceres. Viçosa, 19. $(102): 248-260$.

BRAGA, J.M. e J. YANNER, 1968. Estudo de correlação da análi se química de solo e da planta em cultura de milho. Experientiae, $8(5): 164-196$.

BRAY, R.H. E I.T. KURTZ; 1945. Determination of total, organic and available forms of phosphorus in soils. Soil Sci., 59: 39-45.

BREMNER, J.M. e C.L. HO, 1961. Use of ion exchange resines for extraction of soil organic matter. Agr. Abs. Am. Soc. Agr., 15 . 
CABALA, R.P. H.W. FASSBENDER, 1970. Formas de fósforo en suelos de la región cacaotera de Bahia, Brasil. Turrialba, Costa Rica, 20 (4): 439-444.

CABALA, R.P. e M.B.M. SANTANA, 1972. Comparison of chemical extractants of phosphorus in soils of southern Bahia. Turrialba. $22(1): 19-26$.

CATANI, R.A., 1947. Contribuição ao estudo dos fosfatos, sua dosagem, extração e distribuição nos solos do Estado de São Paulo. Piracicaba, ESALQ/USP, 65 p. (Tese de Doutora mento).

CATANI, R.A. e O.C. BATAGLIA, 1968. Formas de ocorrência do fósforo no solo latossólico roxo. Anais da ESALQ, Piracicaba, 25:99-119.

CATANI, R.A., J.R. GALLO e H. GARGANTINI, 1955. Amostragem de solo, mëtodos de anälises, interpretacão e indicacões gerais para fins de fertilidade. Inst. Agr. Campinas, Bole tim no 69, 29 pp.

CATANI, R.A., A.C. NASCIMENTO e J.R. GALLO, 1957. Formas de ocorrência do fósforo nos solos do'Estado de São Paulo. Re vista de Agricultura, Piracicaba, 32(3): 147-163.

CHANG, S.C., 1965. Application of phosphorus fractionation to the study of the chemistry of available soil phosphorus. Soir and Fert. in Taiwan, p. 1-15.

COSGROVE, D.J., 1963. The chemical nature of soil organic phosphorus. I. Inositol phosphates. Aust。J. Soil Res., 1: $203-214$.

COSGROVE, D.J., 1967. Isolation of Myo-Inositol pentaphosphates hydrolysates of phytic acid. Biochem. J., 89: $172-175$.

COSGRAVE, D.J., 1972. The origin of inositol polyphosphates in soil. Some model experiments in aqueous systems involvin the chemical phosphorilation of myo-inositol and 
the epimerization of myo-inositol pentaphosphates. Soil Biol. Biochem., 4:387-396.

DAHNKE, W.C., J.L. MALCOM e M.E. MENENDEZ, 1963. Phosphorus fractions in selected soil profiles of El Salvador as related to their development. Soir Sci., 87(2): 100-104. DALAL, R.C., 1973. Estimation of available phosphorus in soils by extraction with sodium hidronidesodium carbonate solution. Journal of the Australian Institute of Agricultural Science. 39(2): 142-143.

DAZA, B.J. e L.R. MÜLLER, 1965. Comparaciōn de cinco métodos químicos para la determinación de fósforo aprovechable en algunos suelos tropicales. Turrialba. 15 (3): 249-251.

DHILLON, N.S., A.S. SIDHU e G. DEV, 1977. Evaluation of phosphorus availability indices and establishement of critical limit for available $P$ in alkaline soils of Punjab. Indian Journal of Agricultural Research. 11(3): 142-146. DICK, W.A. e M.A. TABATABAY, 1977. Determination of orthophosphate in aqueous solutions containing labile organic and inorganic phosphorus compounds. J. Environ. Qual. $\underline{6}: 82-85$.

DORMAAR, J.F. e G.R. WEBSTER, 1963. Determination of total organic phosphorus in soils by extraction methods. Cand. J. Soir sci., 43: 35-42.

ENWEZOR, W.O., 1977. Soil testing for phosphorus in some Nigerian soils: I. Comparison of methods of determining available phosphorus in soils of southeastern Nigeria. Soir Sci., 43: 35-42.

FARDEAU, J.C., D. DELILLE e C. ABRAMOVICI, 1968. Utilisation de la phytine par les plants. In: Isotopes and Radiation in soil organic matter studies., Inter. Atom. Ener. Agen. Vienna, pp. 555-565. 
FASSBENDER, H.W., 1966. Descripción físico-quimica del siste ma fertilizante fosfato-suelo-planta. Turrialba, 16(3):237246.

FASSBENDER, H.W., L. MULLER e F. BALERDI, 1968. Estudio del fósforo en suelos de América Central: II. Formas y su relación con las plantas. Turriazba, 18:333-347.

FERREIRA, M.E., F.A,F, MELLO e M.O.C. DO BRASIL SOBRINHO, 1978. Comparação entre três técnicas de extração de $\mathrm{P}$ solüvel. do solo. Cientifica, 5 (3): 244-249.

FOLE, D.A. e S.S. GRIMN, 1973. Avaliação do efeito residual do fósforo por meio de métodos de extração e modelos matemáticos no oxissolo Passo Fundo. Agron. Sulriograndense, Porto Alegre, $\underline{9}(2):$ 205-221.

FRIED, M. e H. BROESHART, 1967. The soil-plant system, in relation to organic nutrition. New York, Academic Press, $358 \mathrm{pp}$.

FRIEND, M.T. e H.F. BIRCH, 1960. Phosphate response in relation to soil tests and organic phosphorus content. $J$. Agr. Sci., 54:341-347.

FURUKAWA, H. e K. KAWAGUCHI, 1969. Contribution of organic phosphorus to the increase of easily soluble $P$ in waterlogged soil, especially realted to phytic phosphorus (I.H.P.). J. Sci. Soil and Manure, Japan, $40(4):$ 141-148. GAYANDE SAMPAT, A., 1973. Fisica de Suelos, Principios y Aplicaciones. Ed. Simusa Wiley S.A., p. 40. GONZALEZ, T.R., R.L. AVILAN, L.C. LEON, A. CHIRINOS e I. DE ROJAS, 1976. Métodos de análisis de suelos de Portuquesa (Venezuela) estudiados en invernadero. Agr. Tropical, $\underline{26}$ (5) : 393-408.

GONZÁLEZ, T.R. e S.R. PEREZ, 1976. Determination of phosphorus in Yaracuy soils in relation to field experiments. Agr. Tropical; 26 (1): 15-29. 
GRUNES, D.L., H.R. HAISE, F. TURNER e J. ALESSI, 1963.

Relationship between yield response to applied fertilizers and laboratory measures of nitrogen and phosphorus availability. Soil Sci. Soc. Am。Proc, 27: 675-679.

HAGIN, J. e J. HILLINGER, 1964. Methods for determination of available phosphorus for peanuts. In: $8^{\text {th }}$ Intern. Congres of Soir Sci。, Bucharest, pp. 5-14.

HAGIN, J:, J. HILLINGER e A, OMERT, 1963. Comparison of - several ways of measuring soil phosphorus availability. J. Agric. Sci., 60: 245-249.

HALM, A.T., 1968. Correlation of soil tests for available phosphorus with crop yield. Ghana J. AGric. Sci。, 1:29-33 .

HANNAPEL, R.J., W.H. FULLER, S. BOSMA e J.S. BULLOCK, 1964a. Phosphorus movement in a calcareous soil. I. Predominance of organic forms of phosphorus in phosphorus movement. Soir Sci., $97(5):$ 530-557.

HANNAPER, R.J., W.H. FULLER e R.H. FOX, 1964b. Phosphorus movement in a calcareous soil. II. Soil microbial activity and organic phosphorus movement. Soir sci., 97 (6) : $421-427$.

HANCE, R.J. e G. ANDERSON, 1963. Identification of hydrolisis products of soils phosphorus. Soil Sci., 96: 157-161.

HERNANDO, V., V. LOMBARDIA E M.T. PARDO, 1970. Correlations between the active fractions of soil phosphorus and their availability to wheat. Phosphorus in Agriculture, 56: 35-41 .

HESSE, P.R., 1971. A Textbook of Soil Chemical Analysis. JOHNS MURRAY, Eds., pp. 295.

HONG, C.K. e I. YAMANE, 1975. A comparison of three methods 
used for determining total organic phosphorus in soil. $J$. Sci. Soiz and Manure, Japan, $\underline{46}(5): 185-191$.

ISLAM, A. e B. AHMED, 1973. Distribution of inositol phosphates phospholipids, and nucleic acids and mineralization of inositol phosphates in some Bangladesh soils. J. Soil Sci. 24: 193-198.

IVANOV, S.N., 1970. A new principle of determining the fertilizer requirements of plants in relation to the nutrient content of the soil. In: $8^{\text {th. Intern. Congress }}$ of Soil Sci., Bucharest, pp. 861-867.

JACKSON, M.L., 1964. Chemical composition of soils. In: Chemistry of the soil. 2a ed. Bear, F.E. editor, Reinhold Publ. Corp., New York, pp. 71-144.

JACKSON, M.L., 1970. Anälisis Quimico de Suelos. 2a ed. MARTINEZ, J.B., Trad. Barcelona, Ed. Omega S.A., 662 p. JACKSON, M.L., S. VACHAROTAYAN, L. ALBAN e R. PETERSON, 1964. Phosphorus availability in reddish brown lateritic soils: II. Relationships between fiel greenhouse, and soil analises. Agron。 J. Madison, 56: 558-560.

JACQUIN, F. e P. SASPORTES, 1968. Dynamique du phosphore organique. Trans. $9^{\text {th. }}$ Intern. Congr. Soil Sci., II: 311319 .

JOSHI, D.C. e S.N. SAXENA, 1972. Distribution of organic phosphorus in humus fractions. J. Ind. Soc. Soil Sci., 20 (2) : $117-120$.

JUANG, T.C. e S.L. FANG, 1965. Comparative study on the soil testing methods for determining available phosphorus of Taiwan sugarcane soils. Soils Fertiz. Taiwan 1965: 34-39. KACAR, B., F. DIDEHVAR e E. SHOKRAVI, 1967. Evaluation of various methods for the estimation of plant available phosphorus in the soils of Caspian sea area (Iran). Yb Fac. agric。 Univ. Ankara, Turkey 7: 140-150. 
KAILA, A., 1963. Organic phosphorus in Finnish soils. Soil Sci. $\quad 95(1): 38-44$.

KARIN, A. e D.H. KHAN, 1965. Relationship between pH an different forms of phosphorus in some soils of east pakistan. Soil Sci. Baltimore, 80: 229-233.

KOTELEV, V.V., 1953. The aplication of bacterial fertilizers to the Kalavash region. Results of 1953 tests. Izvest. Molda. Filiala Akad. Nauk. SSR, 5: 77-85.

KOTELEV, V.V., E.A. MEKHTIEVA e V.I. SMIRNOV, 1960.

- Phosphatase acitivity of some soils and rhizospheres of cultivated plants. Soil and Fert. Abastr., 24: no 2550.

KUZ'MICH, M.A. e Y.K. CHUPRIKOV, 1979. A comparison of methods for determining available phosphate in derno-podzolic gleyey soils. Izv. Timir. Sel. Akad., 5: 79-87.

KURTZ, L.T., 1942. Elimination of fluoride interference in the molybdenum blue reaction. Indust. Engin. Chem. Urbana, $14(11): 15$.

L'ANNUNZIATA, M.F., 1975. The origen and transformations of the soil inositol phosphate isomers. Soil Sci. Soc. Am. Proc., 39: 377-379.

MACLEAN, A.A., J.J. DOYLE e F.G. HEMLYN, 1955. Fertility studies on some New Brunswick soils. Soil phosphorus supply as shown by greenhouse and chemical tests. Can. J. Agr. Sci. 35: 388-396.

MARTIN, J.K., 1964. Soil organic phosphorus. I. Methods for the extraction and partial fractionation of soil organic phosphorus. New Zeal. J.AGric. Res., 7: 750-760.

MATTINGLEY, G.E., 1965. Determining total phosphorus in soils. In: Rothamsted Exp. Stn. Rep., pp. 71-72.

MEHLICH, A., 1953. Determination of P. Ca, Mg, K, Na and $\mathrm{NH}_{4}$, by North Carolina soil testing laboratories. Univ. of N. Carolina, Raleigh, 1953. 
MEHTA, N.C., J.O. LEGG, C.A. GORING e C.A. BLACK, 1954. Determination of organic phosphorus in soil: I. Extraction method. Soil Sci. Soc. Amer. Proc., 18: 443-449.

MELSTED, S.W., 1967. The philosophy of soil testing. In: Soil testing and plant analysis. Madison, Soil Sci. Soc. Am. Inc., Publishers, pp. 13-23 (SSSA Special Publications Series, no 2).

MORTENSEN, J.L. e F.L. HINES, 1964. Soil organic mater. In: Chemistry of the soil. 2a ed., Bear, F.E., editor. Reinhold Publ. Corp., New York, pp. 206-241.

MOSEUR, U.S., W.H. SUTHERLAND e C.A. BLACK, 1959. Evaluation of laboratory index of absorption of soil phosphorus by plants. Pl. Soir, 10: 356-374.

MURPHY, J. e J.P. RILEY, 1962. A modified single solution method for the determination of phosphorus in natural water. Anal. Chim. Acta., 27: 31-36.

MCKERCHER, R.B. e G. ANDERSON, 1968. Content of inositol penta- and hexa-phosphates in some canadian soils. J. Soil. Sci., 19(1): 47-55.

NEPTUNE, A.M.L., 1976. O fósforo no solo. In: Curso de Nutricãa de plantas, Fertilidade do solo, adubos e adubação. USP. ESALQ. (mimeografado)

OKE, O.L., 1970. Chemical determination of readily available phosphorus in soils. J. Indian Soc. Soir Sci., 18(1): 1-3. OLSEN, S.R., C.V. COLD, F.S. WATANABE e L.A. DEAN, 1954. Estimation of available phosphorus in soils by extraction with sodium bicarbonate. U.S. Department of Agriculture, Washington D.C., Circular ne 939.

OLSEN, S.R. e M. FRIED, 1957. Soil phosphorus and fertility. In: Soil, the yearbook of agriculture, Washington, pp. 94: 100 . 
OMOSTOSO, T.I., 1971. Organic phosphorus contents in some cocoa growing soils of southern Nigeria. Soil Sci., 112 (3) : 195-199.

PASQUAL, A. e A.M.L. NEPTUNE, 1976. Efeito de doses elevadas de fósforo em produção de milho e nas principais formas de ocorrência deste nutriente em dois solos do Estado de são Paulo. IX Reunião Brasileira de Fertilidade do Solo, Belo Horizonte, MG.

PAYNE, H. e W.J. HANNA, 1965. Correlations among soil phosphorus fractions, extractable phosphorus and plant content of phosphorus. J. Agric. Fd. Chemy., 13: 322-326. PEECH, M. e L. ENGLISH, 1944. Rapid microchemical soil tests. Soil Sci。, 57: 167-195.

PEREIRA, J.R. e C:M.B. FARIA, 1977. Avaliação da disponibili dade de fósforo em um vertissol do médio são Francisco por diversos métodos, In: Congresso Brasileiro de Ciência do Solo, 16, São Luiz, 15 p.

PEREZ MENDEZ, J.A., F. GUTIERREZ, E. FERNANDEZ e J.C. TRUJILLO, 1978. Estude comparative de méthodes pour la détermination du phosphore total dans différents types d'andosols. Science du Sol, 4:241-250.

PICHOT, J: e P. ROCHE, 1972. Phosphore dans les sols tropicaux. L'Agronomie Tropicale, 27: 939-965.

PIMENTEL GOMES, F., 1970. Curso de Estatistica Experimental. 4 ạ ed., São Paulo. Livraria Novel S.A. 430 p. PRATT, P.F. E M.J. GARBER, 1964. Correlations of phosphorus availability by chemical tests with inorganic phosphorus fractions. Proc. Soil Sci. Soc. Am., 28: 23-26. RESENDE, T.R.C., 1977. Estudo do fósforo em alguns solos do Estado da Bahia (fracionamento e teor total de $\mathrm{P}$. relação $\mathrm{C} / \mathrm{N}$ e comparação de métodos químicos para $\mathrm{P}$ assimilável ). In: Congresso Brasileiro de Ciência do Solo, 16 , Saõ Luiz, 
$11 \mathrm{p}$.

RUSSELL, E.W., 1973. Soil conditions and plant growth, $10^{\text {th }}$ ed., Logmans Green, New York, 263 pp.

SA, J.P.M., S.M.C. ARAUJO, S.J. GALVÃO, A.L. DE VASCONCELOS e E.S.C. OLIVEIRA, 1974. Evaluation of methods of chemical analysis for available phosphorus in soils of the "zona Litoral-Mata" of Pernambuco. Pesquisa Agrop. Brasizeira, Agronomia, 9 (9): 27-33.

SAHRAWAT, K.L., 1977. EDTA extratable $\mathrm{P}$ in soils as related to available and inorganic P forms. Soil Sci. Pl. Anal., 8(4): 281-287. Appud: Phosphorus in Agriculture, 1978, 32, no 5 .

SAUNDERS, W.M.H. e E.G. WILLIAMS, 1955. Observation on the determination of total organic phosphorus in soils. $J$. soir sci., $6(6): 254-267$.

SHERREL, C.G. e W.M.H. SAUNDERS, 1966. An evaluation of methods for the determination of total phosphorus in soils. N.Z. JI. Agric. Res., 9: 972-979.

SIBBESEN, E., 1977. A simple ion-exchange resin procedure extracting plant available elements form soils. Plant soil, 46: 665-669.

SMITH, F.W. e R.L. COOK, 1953. A study of the relationship: between chemically available phosphorus and plant growth response on several Michigan soils. Proc. Soil Sci. Soc. $A m$ 。17: 26-30.

SMITH, A.N., 1970. Fractionation of inorganic phosphorus in soils, the Chang and Jackson fractionation procedure: its limitations and uses. Agridigest, 17:10-19.

SOMMERS, L.E. E D.W. NELSON, 1972. Determination of total phosphorus in soils. A rapid perchloric acid digestion procedure. Soiz Sci. Soc. Am. Proc., 36:902-904. 
STRICKLAND, K.P., 1975. Form and function of phospholipids. J.N. Howthorne, G.B. Ansell and R.M.C. Dawson, eds., pp. 9-42. Elsevier, Amsterdan.

SUSUKI, A., K. LAWTON e E.C. DOLL, 1963.. Phosphorus uptake and soils tests as related to forms of phosphorus in some Michigan soils. Soil Sci. Soc. Am. Proc., 27:401-403. SYRES, J.K., J.D.H. WILLIAMS, A.S. CAMBELL e T.W. WALKER, 1967. The significance of apatite inclusions in soil phosphorus studies. Soil Sci. Am. Proc., 31: 752-756.

SYRES, J.K., J.D.H. WILLIAMS, E.H. TYNER e T.W. WALKER, 1969 . Primary and secondary origin of 'nonextractable' soị inorganic phosphorus. Soiz Sci. Soc. Am..Proc., 33: 635636.

SYRES, J.K., J.D.H. WILLIAMS e T.W. WALKER, 1968. The determination of total phosphorus in soils and parent materials. New Zeal. J.Agric. Res., 11: 757-762.

SWIFT, R.S. e A.M. POSNER, 1972. Nitrogen, phosphorus and Sulfur contents of humic acids fractionated with respect to molecular weight. J. Soil Sci., 23(1): 50-57.

SZEMBER, A., 1960. Influence on plant growth of the breakdown of inorganic phosphorus compounds by microorganisms. PZ. Soil, 12 (2): 147-158.

TATE, K.R., 1979. Fractionation of soil organic phosphorus in two New Zeland soils by use of sodium borate. New Ze.Zand J. Sci., 22(2): 137-142.

TORRES, B.M. e T.E. ORTEGA, 1972. Correlacion Y calibración de diferentes métodos de análisis químico de fósforo asimilable para los suelos de la zona de influencia de Cha pingo, México. Agrociéncia, $\mathrm{C}(7):$ 47-63.

TITTERINGTON, J.M. e E.C. VARSA, 1975. A comparison of P extraction methods on soil of Rio Grande do Sul - Brazil. Agron. Abst. Amer. Soc. Agron. 194. In: Phosphorus in Agriculture. Paris, 28: 36. 
TRUOG, E., 1930. The determination of the readily available phosphorus of soils. J.Amer. Soc. Agron., 22: 874-882. ULTRAFERTIL, 1980. Guia de adubasão Ultrafertil, 3ą ed., Depto de Serviços Técnicos Agronômicos, pp. 27.

VELAYTHAM, M. e J.M. JAIN, 1972. Preliminary studies on the development of an ideal soil test for available $P$ for rice (in the black soil fo Coimbatore based on availability of different forms of soil $P$ to the cropl under field conditions.(R). Int. Symp. Soil Fert. Eval., New Delhi (India), 134-143. In: Phosphorus in Agriculture, Paris, 59-41. VIDOR, C. e J.R.J. FREIRE, 1971. Calibração de análises de so lo para a cultura de soja (Glycine max), Agron. Sulriogran dense, Porto Alegre, 7: 63-72.

VIEIRA, L.S., 1971. Teor de fósforo orgânico em alguns solos do Pará. Série Monografias 6. IDESF - Belém, Pará.

WALMSLEY, D. e I.S. CORNFORTH, 1973. Methods of measuring available nutrients in West Indian soils. II. Phosphorus. Pl. Soil, 39: 93-iol.

WARREN, R.G. e G.W. COOKE, 1962. Comparisons between methods of measuring soluble phosphorus and potassium in soils used for fertilizers experiments on sugar beet. J. Agric. Sci. 59: 269-274.

WELLS, N. e W.N.H. SAUNDERS, 1960. Soil studies using sweet vernal to ossess element availability. IV. Phosphorus. Néw Zeal. J. Agric. Res., 3: 279-299.

WILLIAMS, R.J.B. e G.W. COOKE, 1965. Measuring soluble phosphorus in soils, comparison of methods, and interpretation of results. Tech. Bulz. Minist. Agric. Fish. 13: 84-93.

WILLIAMS, J.D.H. e T.W. WALKER, 1967. Comparison of "ignition" and "extraction" methods for the determination of organic phosphate in rocks and soils. Pl. Soil, 27 : 457-458. 